



\section{Minder hondenbeten}

Puzzelen naar veiligheid voor mens en dier

Francesca Neijenhuis, Marion Kluivers en Hans Hopster

Wageningen Livestock Research

Dit onderzoek is uitgevoerd door Wageningen Livestock Research, in opdracht van de gemeente Amsterdam

Wageningen Livestock Research

Wageningen, december 2017

Rapport 1024 
Neijenhuis, F., Kluivers M., Hopster H., 2017. Minder hondenbeten. Puzzelen naar veiligheid voor mens en dier. Wageningen Livestock Research, Rapport 1024.

\section{Samenvatting NL}

Dit rapport bevat adviezen aan de gemeente Amsterdam hoe te komen tot een reductie van het aantal bijtincidenten met honden en voor haar burgers tot een verhoging van de reële en ervaren veiligheid. Oorzaken van bijtincidenten zijn op basis van de literatuur in kaart gebracht en cijfers over de aard en omvang van bijtincidenten zijn geactualiseerd voor zowel Nederland als voor de gemeente Amsterdam. De geadviseerde maatregelen zijn opgedeeld in twee onderdelen: repressieve maatregelen (advies bijtprotocol), volgend op een bijtincident dat al is opgetreden en bedoeld om herhaling te voorkomen, en preventieve maatregelen, bedoeld om nieuwe bijtincidenten te voorkomen. Tenslotte zijn er adviezen opgenomen aangaande een betere registratie van honden, van bijtincidenten met honden en betreffende de ontwikkeling en het gebruik van een lijst met hoog-risico honden.

\section{Summary UK}

This report contains advice to the municipality of Amsterdam on how to reduce the number of dog bites thus increasing real and perceived safety for its citizens. Causes of dog bites have been identified on the basis of the literature and figures on the nature and extent of biting incidents have been updated for both the Netherlands and the municipality of Amsterdam. The recommended measures are divided into two parts: repressive measures (biting protocol advice), following a bite incident that has already occurred thus preventing recurrence, and preventive measures intended to prevent new bite incidents. Finally, advice has been included regarding better registration of dogs, of bite incidents with dogs and the development and use of a list of high-risk dogs.

Dit rapport is gratis te downloaden op https://doi.org/10.18174/428257 of op www.wur.nl/livestock-research (onder Wageningen Livestock Research publicaties).

Foto titelblad: @Shutterstock

(c) 2017 Wageningen Livestock Research

Postbus 338, 6700 AH Wageningen, T 03174839 53, E info.livestockresearch@wur.nl, www.wur.nl/livestock-research. Wageningen Livestock Research is onderdeel van Wageningen University \& Research.

Wageningen Livestock Research aanvaardt geen aansprakelijkheid voor eventuele schade voortvloeiend uit het gebruik van de resultaten van dit onderzoek of de toepassing van de adviezen.

Deze studie is goedgekeurd volgens de governance code van NIVEL Zorgregistraties, onder nummer NZR-00317.026

Het gebruik van gegevens uit elektronische patiëntendossiers, zoals vermeld door NIVEL Zorgregistraties eerste lijn, is door de Nederlandse wet, onder bepaalde voorwaarden toegestaan, zonder dat van iedere individuele patiënt daarvoor toestemming wordt gevraagd of dat toetsing door een medisch ethische commissie heeft plaatsgevonden (Burgerlijk wetboek, art. 7:458).

Alle rechten voorbehouden. Niets uit deze uitgave mag worden vermenigvuldigd en/of openbaar gemaakt worden door middel van druk, fotokopie, microfilm of op welke wijze dan ook zonder voorafgaande toestemming van de uitgever of auteur.

De certificering volgens ISO 9001 door DNV onderstreept ons kwaliteitsniveau. Op als onze onderzoeksopdrachten zijn de Algemene Voorwaarden van de Animal Sciences Group van toepassing. Deze zijn gedeponeerd bij de Arrondissementsrechtbank Zwolle. 


\section{Inhoud}

Woord vooraf

1

1.1 Opdracht

1.2 Leeswijzer

$\begin{array}{lll}2.1 & \text { In Nederland } & 13\end{array}$

2.2 In Amsterdam $\quad 13$

$3 \quad$ Aard en omvang van bijtincidenten op basis van literatuur

15

3.1 In Nederland $\quad 15$

$\begin{array}{ll}3.2 & \text { In andere landen }\end{array}$

4

Risicofactoren voor een bijtincident zoals aangegeven in de literatuur

19

4.1 Hond

4.2 Eigenaar/houder $\quad 26$

$\begin{array}{lll}4.3 & \text { Context } & 27\end{array}$

$\begin{array}{lll}4.4 & \text { Conclusies uit de literatuur } & 29\end{array}$

5

$\begin{array}{ll}\text { Actuele cijfers uit Nederland } & \mathbf{3 1}\end{array}$

5.1 Meldingen bij de politie $\quad 31$

$\begin{array}{lll}5.2 & \text { Behandeling door de huisarts } & 31\end{array}$

$\begin{array}{lll}5.3 & \text { Behandeling bij de spoedeisende hulp } & 32\end{array}$

$\begin{array}{lll}5.4 & \text { Opname in een ziekenhuis } & 34\end{array}$

5.5 Aantal mensen overleden aan een hondenbeet $\quad 35$

$\begin{array}{lll}5.6 & \text { Ras(type) hond die heeft gebeten } & 36\end{array}$

$\begin{array}{lll}5.7 & \text { In beslag genomen honden } & 36\end{array}$

$\begin{array}{llr}6 & \text { Actuele cijfers uit Amsterdam } & 38\end{array}$

6.1 Meldingen bij de politie $\quad 38$

6.2 Behandeling door de huisarts $\quad 39$

$\begin{array}{lll}6.3 & \text { Behandeling bij de spoedeisende hulp } & 40\end{array}$

$\begin{array}{lll}6.4 & \text { Opname in een ziekenhuis } & 41\end{array}$

$\begin{array}{lll}6.5 & \text { Behandeling bij een dierenarts } & 41\end{array}$

6.6 Aantal mensen overleden aan een hondenbeet $\quad 42$

6.7 Aantal dieren overleden aan een hondenbeet $\quad 42$

6.8 Ras(type) hond die heeft gebeten $\quad 42$

6.9 Ernst en toedracht van bijtincidenten $\quad 43$

6.10 In beslag genomen honden $\quad 44$ 
8.1 Inleiding $\quad 51$

8.2 Ernst van het letsel $\quad 51$

8.3 Repressieve maatregelen $\quad 52$

$9 \quad$ Conclusies en aanbevelingen $\quad 58$

9.1 Reële veiligheid $\quad 58$

9.2 Ervaren veiligheid $\quad 59$

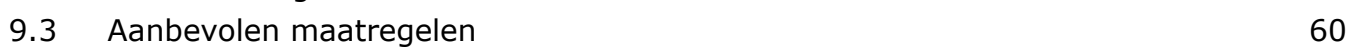

9.4 Gebruik van de HR-lijst $\quad 62$

9.5 Financiering voorgestelde maatregelen $\quad 63$

10

Literatuur

64

$\begin{array}{llr}\text { Bijlage } 1 & \text { Expert interviews } & 69\end{array}$

$\begin{array}{llr}\text { Bijlage } 2 & \text { Geraadpleegde registratiesystemen } & 74\end{array}$ 


\section{Woord vooraf}

De opdracht van de gemeente Amsterdam om een advies over wat genoemd werd 'het bijtprotocol' bleek een intrigerende puzzel. Wij hadden ingeschat dat deze uit veel stukjes zou bestaan, en kwamen er al doende achter welke er misten. Gelukkig was er een grote bereidheid bij veel partijen om puzzelstukjes aan te dragen. Wij bedanken het team hondengeleiders van de politie Amsterdam, VeiligheidNL, Medisch Centrum voor Dieren MCD-Anicura, NIVEL Zorgregistraties eerste lijn, geïnterviewde deskundigen en de Rijksdienst voor Ondernemend Nederland. Met hun hulp is het tenslotte gelukt om een deel van de puzzel te leggen. Wij vinden dat het beeld dat daaruit ontstaat voldoende duidelijk is om Amsterdam te adviseren over te nemen maatregelen, maar pleiten tegelijkertijd voor een betere registratie van honden en bijtincidenten met honden.

In het bijzonder danken wij Sylvia Meintser, beleidsmedewerker Dierenwelzijn van de gemeente Amsterdam voor de plezierige samenwerking. Door als gemeente een workshop te organiseren waarin voorlopige resultaten uit dit onderzoek met partijen zijn gedeeld en visies zijn uitgewisseld, heeft Amsterdam laten zien zich bewust te zijn van het belang van dit onderwerp. Met de adviezen in dit rapport kan de gemeente Amsterdam haar beleid aangaande honden verder vorm geven.

Dr. Annemarie Rebel, Hoofd afdeling Diergezondheid en Dierenwelzijn, Wageningen Livestock Research 


\section{Managementsamenvatting}

\section{Aanleiding}

De aanleiding voor dit advies is het voornemen van de gemeente Amsterdam om een aanpak te ontwikkelen om het aantal bijtincidenten door honden terug te dringen. Het advies bevat aanbevelingen die zijn opgedeeld in twee onderdelen: repressieve maatregelen (advies bijtprotocol), volgend op een bijtincident dat al is opgetreden en bedoeld om herhaling te voorkomen, en preventieve maatregelen, bedoeld om nieuwe bijtincidenten te voorkomen.

\section{Situatie in de gemeente Amsterdam}

In Amsterdam ligt het aantal meldingen bij de politie van een 'gevaarlijke hond' rond de 200 per jaar. In 158 gevallen is er sprake van een incident waarbij vrijwel altijd een slachtoffer door een hond is gebeten; in 42 gevallen betreft het een hinderlijke situatie waarbij een hond is betrokken. In totaal is van $4,1 \%$ van de 158 gemelde incidenten aangifte gedaan. Meer dan de helft van de meldingen betreft incidenten waarbij dieren (voornamelijk andere honden) werden gebeten. In $57 \%$ van de gevallen liep de hond die beet los, was deze losgebroken of ontsnapt.

Voor wat betreft menselijke slachtoffers (aantal per 100.000 inwoners per jaar) lijkt de situatie in Amsterdam in vergelijking met die in Nederland niet ongunstig; 300 vs. 460 mensen die zich bij de huisarts hebben gemeld, 9,1 vs. 15,4 mensen bij de spoedeisende hulp, 0,12 vs. 0,8 mensen die zijn opgenomen in het ziekenhuis. Hierbij moet aangetekend worden dat de gegevens over SEH-bezoeken en ziekenhuisopnames uitsluitend zijn gebaseerd op registraties bij het AMC en het VU-ziekenhuis. Van het aantal dierlijke, niet bij de politie geregistreerde slachtoffers ontbreekt een betrouwbaar beeld.

\section{Advies repressieve maatregelen (Advies bijtprotocol)}

In het Advies bijtprotocol worden de maatregelen volgend op een bijtincident beschreven, dit omvat drie onderdelen: registratie van het incident, beoordelen van de ernst van het incident en vaststellen van de maatregelen volgend op het incident. Maatregelen ten aanzien van het slachtoffer zijn hierin niet opgenomen; naast fysieke schade kan de mentale impact van het incident op het slachtoffer (mens of dier) echter groot zijn. De mogelijkheden voor psychische (na)zorg dienen daarom onder de aandacht gebracht te worden.

\section{Registratie incident}

Bijtincidenten ontstaan uit een samenspel tussen verschillende factoren die globaal zijn toe te wijzen aan eigenschappen van de hond, aan hoe de eigenaar/begeleider met de hond omgaat en de context waarin de hond tot het bijten van het slachtoffer is overgegaan. Een eenduidige registratie is essentieel om een dossier op te kunnen bouwen over de veroorzakers van bijtincidenten (zowel hond als eigenaar/houder). Met een betrouwbare registratie kan de identiteit van de bijtende hond onomstotelijk vastgesteld worden, zodat disciplinaire maatregelen opgelegd en gehandhaafd kunnen worden.

\section{Ernst letsel}

Het ontstane fysieke letsel bij het slachtoffer wordt onderverdeeld in drie categorieën: licht, ernstig en zeer ernstig letsel, omdat de gedragsmotivatie en de mate van agressie van de bijtende hond in de drie categorieën verschillend is en daarmee ook het risico op recidive en de te volgen aanpak. Het onderscheid tussen ernstig en zeer ernstig wordt gemaakt op basis van het slachtoffer, nl. dier of mens. Dit onderscheid is noodzakelijk, omdat bij een aanval van een mens met ernstig letsel of de dood tot gevolg sprake is van disproportionele agressie die directe inbeslagname van de hond noodzakelijk maakt, om het risico voor de omgeving weg te nemen. Onderverdeling in meer categorieën lijkt niet te verkiezen, doordat er enerzijds meer onduidelijkheid kan ontstaan over de 
juiste categorie en anderzijds de opdeling van de maatregelen in meer dan drie te volgen trajecten niet zinvol lijkt (op basis van het gedragsprobleem van de veroorzakende hond).

\section{Maatregelen volgend op incident}

Bij een (eerste) licht bijtincident wordt een waarschuwingsbrief verzonden naar de eigenaar van de bijtende hond waarin wordt aangegeven dat de gemeente de hond hinderlijk acht en een waarschuwing voor de hond oplegt aan de eigenaar. Van de eigenaar wordt verwacht dat hij maatregelen zal treffen om herhaling te voorkomen.

Bij een tweede melding van een licht bijtincident binnen twee jaar na het voorgaande bijtincident wordt de opvolging van het incident als bij een ernstig bijtincident.

Bij een ernstig bijtincident besluit de gemeente tot gevaarlijkverklaring van de hond. De hond krijgt een kort aanlijn- en muilkorfgebod opgelegd welke ook gelden voor de losloopgebieden in de gemeente. De eigenaar dient veiligheidsmaatregelen te treffen in de woning, tuin of erf om te voorkomen dat de hond zonder begeleiding de woning, de tuin of het erf kan verlaten.

Heroverweging van de gevaarlijkverklaring kan na een periode van één jaar door de eigenaar van de hond aangevraagd worden onder het overleggen van bewijs van een met goed gevolg afgelegde erkende cursus. De hond dient vervolgens een gedragstest te ondergaan bij een gecertificeerde instelling.

Bij een zeer ernstig bijtincident, waarbij sprake is van disproportionele agressie leidend tot weefsel- of functieverlies, gaat de gemeente direct over tot inbeslagname. De hond wordt in opslag geplaatst, waarna binnen 1 tot 2 weken een gedragstest wordt afgenomen. Op basis van de test wordt besloten of en onder welke voorwaarden de hond terug kan naar de eigenaar, elders herplaatst moet worden of geëuthanaseerd moet worden.

\section{Advies preventieve maatregelen te nemen door de gemeente Amsterdam}

Naast adviezen voor repressieve maatregelen (om herhaling van een bijtincident te voorkomen) zijn er in dit rapport ook adviezen beschreven voor preventieve maatregelen (gericht op het wegnemen van oorzaken van een bijtincident) die de gemeente Amsterdam kan inzetten om het aantal bijtincidenten terug te dringen.

- Inrichting van een puppyconsultatiebureau voor veterinaire basiszorg, preventie van gedragsproblemen bij honden in de leeftijd van 0-2 jaar en ondersteuning van verantwoordelijk gedrag bij de eigenaar. Uitvoering ligt bij de dierenartsenpraktijken in de gemeente;

- Stimuleren van alle puppyeigenaren tot het volgen van minimaal een puppycursus bij een gekwalificeerde instructeur, verplicht deze voor honden met een volwassen gewicht van $>20 \mathrm{~kg}$, aangevuld met een gehoorzaamheidscursus ter verkrijging van een 'sociale hond' certificaat;

- Vergroting van het aantal uitlaatgebieden en/of loslooprennen. Eventueel openstelling op verschillende tijden voor verschillende categorieën honden (bv. wel/geen 'sociale hond' certificaat);

- Opstellen van een gemeentelijke lijst met potentieel gevaarlijke rassen of typen gebaseerd op het aantal geregistreerde incidenten per ras of type ten opzichte van het aantal in Amsterdam aanwezige honden van dat ras of type geldt als basis voor. IJking na elke 3 jaar;

- Verplichten van kort aanlijnen van potentieel gevaarlijke rassen of typen zonder 'sociale hond' certificaat en begeleiding door personen van minimaal 18 jaar;

- Beschrijven in de APV van specifieke eisen met betrekking tot een ontsnappingsveilig erf of verblijf;

- Opleggen van een houdverbod aan eigenaren van honden die in de publieke ruimte twee keer een ernstig of zeer ernstig bijtincident hebben veroorzaakt;

- Verstrekken van een gemeentelijke brochure 'Hondenwijzer' aan hondenbezitters met de regels voor baas en hond alsmede informatie over verantwoord houderschap, gekwalificeerde instructeurs, uitlaatgebieden en loslooprennen, repressieve maatregelen en de APV;

- Versterken voorlichting over veilige omgang van het kind met de hond via specifieke kanalen als verloskundigenpraktijken, consultatiebureaus, basisscholen en dierenspeciaalzaken;

- Creëren van een laagdrempelig en anoniem meldpunt voor gevaarlijke/onveilige situaties (voor mens of dier);

- Verstrekken van een folder over letsel- en shockschade aan slachtoffers van bijtincidenten of (bij dieren) aan hun eigenaren. 


\section{Advies aandringen op maatregelen te nemen door de Rijksoverheid}

Naast de preventieve maatregelen die de gemeente Amsterdam kan treffen, verdient het aanbeveling om bij de Rijksoverheid aan te dringen op de ontwikkeling en implementatie van:

- $\quad$ Een geactualiseerde, gestandaardiseerde, volledige en betrouwbare landelijke registratie van honden (verplichte I\&R ook van honden die voor 1 april 2013 geboren zijn);

- $\quad$ Een geactualiseerde, gestandaardiseerde, volledige en betrouwbare landelijke registratie van bijtincidenten en opgelegde repressieve maatregelen;

- Gekoppelde registratie van honden en incidenten aan letselregistraties bij ziekenhuizen, huisartsen en dierenartsen. 


\section{$1 \quad$ Inleiding}

De aanleiding voor dit project is het voornemen van de gemeente Amsterdam, beschreven in de Agenda Dieren 2015-2018 ${ }^{1}$, een aanpak (protocol) te ontwikkelen waarmee bijtincidenten door honden kunnen worden aangepakt en beperkt.

In 1993 werd de Regeling Agressieve Dieren (RAD) ingesteld nadat kort na elkaar drie kinderen werden doodgebeten door honden van het type Pitbull. De RAD had als doel honden van het type Pitbull te laten uitsterven om zodoende het aantal ernstige bijtincidenten terug te dringen. Er werd een fokverbod en castratieplicht ingesteld en ook een houdverbod voor niet geregistreerde honden van het type Pitbull. In 2008 werd de RAD ingetrokken omdat deze onvoldoende doeltreffend bleek (Commissie van Wijzen, 2008) en omdat de regeling in de samenleving steeds meer weerstand ondervond. Met het opheffen van de RAD werd ook het fokverbod voor honden van het type Pitbull opgeheven. Daarmee keerden honden van dit type terug in het straatbeeld.

In 2013 heeft de Raad voor Dierenaangelegenheden een zienswijze uitgebracht met aanbevelingen om bijtincidenten met honden beter te voorkómen en om het huidige beleid als reactie op bijtincidenten consistenter, effectiever en kostenefficiënter te maken (Raad voor Dierenaangelegenheden, 2013). Daarin werd ook de lokale overheid een expliciete rol toebedacht. Ook partijen die zich bekommeren om het welzijn van in beslag genomen honden hebben voorstellen gedaan in de vorm van een 'stay home protocol ${ }^{2}$ teneinde de problematiek beheersbaar te maken. Wat de keuze voor maatregelen lastig maakt is dat actuele feiten over de aard en omvang van bijtincidenten ontbreken, zowel in Amsterdam als nationaal, waardoor meningen ${ }^{3}$ het publieke debat dreigen te overheersen.

Slachtoffers van bijtincidenten zijn zowel mensen als (huis)dieren. De openbare ruimte in Amsterdam wordt met veel mensen en dieren gedeeld. Honden mogen echter nergens een gevaar vormen. Vanuit het oogpunt van veiligheid en welzijn van mens en dier is het gewenst dat wordt ingegrepen bij hinderlijke, gevaarlijke en agressieve honden ${ }^{4}$.

\section{$1.1 \quad$ Opdracht}

Dit project is bedoeld inzicht te geven in de aard en omvang van bijtincidenten in de gemeente Amsterdam en te komen tot aanbevelingen om bijtincidenten in de openbare ruimte terug te dringen. Het onderzoek omvat een analyse van de aard en omvang van de problematiek en de mogelijke oorzaken op basis van de literatuur. Daarnaast is de aard en omvang van bijtincidenten in de gemeente Amsterdam in beeld gebracht in het licht van geactualiseerde gegevens van bijtincidenten in Nederland aan de hand van gegevens uit diverse bronnen.

Als inspiratiebron voor beleidsmaatregelen zijn de oorzaken van bijtincidenten op basis van de beschikbare literatuur op een rijtje gezet. Tenslotte zijn, voor zover beschikbaar, evaluatiestudies geraadpleegd om de effectiviteit van verschillende beleidsmaatregelen in kaart te brengen.

De resultaten van dit project zijn een advies aangaande een 'bijtprotocol' met mogelijke preventieve en repressieve maatregelen, alsmede deze Nederlandstalige eindrapportage met onderbouwing voor de voorgestelde maatregelen.

\footnotetext{
${ }^{1}$ Er wordt een bijtprotocol opgesteld voor gevaarlijke en agressieve honden. Indien nodig aanpassen APV. Agenda Dieren 2015 - 2018, pagina 25 (Gemeente Amsterdam, 2016a).

2 http://www.hulpinbeslaggenomenhonden.nl/protocol.html

${ }^{3}$ Artikelen Parool: (Het Parool, no date; Meershoek, 2016)

${ }^{4}$ Agenda Dieren 2015 - 2018, pagina 25 (Gemeente Amsterdam, 2016a)
} 


\subsection{Leeswijzer}

Dit rapport bevat adviezen aan de gemeente Amsterdam hoe te komen tot een reductie van het aantal bijtincidenten met honden en voor haar burgers tot een verhoging van de reële en ervaren veiligheid. In hoofdstuk 2 is te lezen hoeveel honden er in Nederland en in Amsterdam worden gehouden. De aard en omvang van bijtincidenten met honden in Nederland en in andere landen is op basis van literatuur beschreven in hoofdstuk 3. In hoofdstuk 4 wordt ingegaan op de oorzaken van bijtincidenten met honden, zoals deze zijn aangegeven in de literatuur. Actuele cijfers over de aard en omvang van bijtincidenten in Nederland zijn gepresenteerd in hoofdstuk 5. Specifiek betreffende de gemeente Amsterdam zijn actuele cijfers over aard en omvang van de hondenbetenproblematiek in hoofdstuk 6 weergegeven. Hoe deze problematiek in andere landen wordt aangepakt en hoe effectief dat is wordt besproken in hoofdstuk 7. In hoofdstuk 8 volgt het advies aangaande het bijtprotocol voor de gemeente Amsterdam. Hoofdstuk 9 sluit af met maatregelen die worden geadviseerd om het aantal hondenbeten terug te dringen. De geadviseerde maatregelen zijn opgedeeld in twee onderdelen: repressieve maatregelen (advies bijtprotocol) en preventieve maatregelen, bedoeld om nieuwe bijtincidenten te voorkomen. Tenslotte zijn er adviezen opgenomen aangaande een betere registratie van honden, van bijtincidenten met honden en betreffende de ontwikkeling en het gebruik van een lijst met hoog-risico honden. 


\section{Houden van honden}

Domesticatie van de hond vond 20.000 - 40.000 jaar geleden plaats (Song et al., 2017), waarschijnlijk op verschillende plaatsen in de wereld en vanuit verschillende soorten, behorend tot het geslacht van de hondachtigen (Canidae) (Vonholdt and Driscoll, 2016). In de Victoriaanse tijd (19e eeuw) maakte het fokken van rashonden opgang met als gevolg de huidige meer dan 350 hondenrassen (Vonholdt and Driscoll, 2016). In Nederland spelen honden in veel huishoudens een belangrijke rol en staan ze dicht bij de mens. Vaak worden ze als 'gezinslid' beschouwd (Blouin, 2013; Maharaj and Haney, 2015; Walsh, 2017). Naast voordelen als gezelschap, bescherming, afleiding en beweging kan het houden van honden ook nadelen met zich meebrengen. Een hond kan bijvoorbeeld onhebbelijk gedrag vertonen, ziek worden, huisraad vernielen of mensen of dieren door te bijten letsel toebrengen. Hondenbeten veroorzaken naast letselschade, incidenteel met de dood van het slachtoffer als gevolg, vaak ook emotionele schade bij het slachtoffer (Craig et al., 2017; Mullins \& Harrahill, 2008). Berichten in de media over ernstige bijtincidenten versterken bij burgers daarnaast het gevoel van onveiligheid. Bijtincidenten zijn en blijven hierdoor een belangrijk maatschappelijk thema (Lockwood, 2016).

\section{$2.1 \quad$ In Nederland}

In Nederland worden naar schatting 1,5 miljoen honden gehouden (Dibevo \& NVG, 2017); het exacte aantal honden is vanwege een onvolledige registratie niet bekend. Op 1 april 2013 is de gewijzigde regeling identificatie en registratie van dieren in werking getreden ${ }^{5}$. Volgens deze regeling is het vanaf die datum wettelijk verplicht dat een in Nederland geboren hond binnen zeven weken wordt geïdentificeerd (gechipt) en binnen acht weken wordt geregistreerd bij een door de overheid erkende databank. Dit betekent dat honden die voor 1 april 2013 zijn geboren, niet onder de verplichte registratie vallen. Bovendien blijkt dat de verplichte registratie van honden nog de nodige onvolkomenheden kent ${ }^{6}$. Hoeveel honden er exact in Nederland worden gehouden en wat de kenmerken zijn van deze honden is derhalve niet goed bekend.

\subsection{In Amsterdam}

Ook het aantal honden in de gemeente Amsterdam is onbekend en schattingen over dit aantal lopen uiteen. Uitgaande van 1,5 miljoen honden in Nederland en een gelijke verdeling van honden over de bevolking, wordt het aantal honden in de gemeente Amsterdam, met ruim 834.000 inwoners (CBS Statline, 2016), geschat op 89.000. Dibevo en NVG (2017) geven echter aan dat in de drie grote steden van Nederland $12 \%$ van de huishoudens een hond heeft. Dit is beduidend minder dan de $19 \%$ gemiddeld in Nederland. Uitgaande van 456.000 huishoudens (gemiddeld 1,8 personen per huishouden in Amsterdam; CBS Statline, 2016) en de genoemde 12\%, betekent dit 55.000 honden. Het aantal honden in Amsterdam (excl. Westpoort) op basis van de betaalde hondenbelasting (i.c. gemeentelijk geregistreerde honden) is echter aanzienlijk lager. Op basis hiervan waren er 19.432 honden in de stad. Dat houdt in dat nog geen $5 \%$ van de Amsterdamse huishoudens een hond zou hebben (Gemeente Amsterdam, 2008b). Wel wordt vermeld dat "bij een steekproef in 2007 bleek ongeveer 10\% niet geregistreerd". In het jaarboek 2008 van de gemeente Amsterdam staat evenwel: "Volgens schattingen van de stadsdelen betekent dit dat ongeveer de helft van de Amsterdamse hondenbezitters deze belasting niet betaalt" (Gemeente Amsterdam, 2008a). Dat het aantal honden waarvoor hondenbelasting werd betaald lager lag dan het daadwerkelijke aantal honden wordt ook ondersteund in de 'Factsheet afschaffing hondenbelasting' (2015). Daarin staat dat uit onderzoek blijkt dat in 201427.000 honden in Amsterdam gehouden werden (Greven and Bosveld, 2014). Dat zou betekenen dat $6 \%$ van de huishoudens een hond heeft.

\footnotetext{
${ }^{5}$ http://wetten.overheid.nl/BWBR0014538/2016-04-01

${ }^{6}$ https://www.nvwa.nl/nieuws-en-media/nieuws/2017/05/17/goede-registratie-van-honden-belangrijk-bij-tegengaanillegale-hondenhandel
} 
In Figuur 1 is het percentage huishoudens met een hond waarvoor in 2008 hondenbelasting is betaald, per stadsdeel weergegeven (exclusief Westpoort). Gemiddeld heeft dan 4,7\% van de huishoudens in de gemeente Amsterdam een hond. In stadsdeel Zuideramstel had slechts 2,2\% van de huishoudens een hond terwijl in Amsterdam-Noord dit 10\% van de huishoudens was (Gemeente Amsterdam, 2008). Voor de gemeente Den Haag lijkt het hondenbezit in diezelfde range te liggen. Afhankelijk van de wijk heeft 2,5 tot $10 \%$ van de Haagse huishoudens een hond (persoonlijke mededeling seminar Hondenbescherming, 2016).

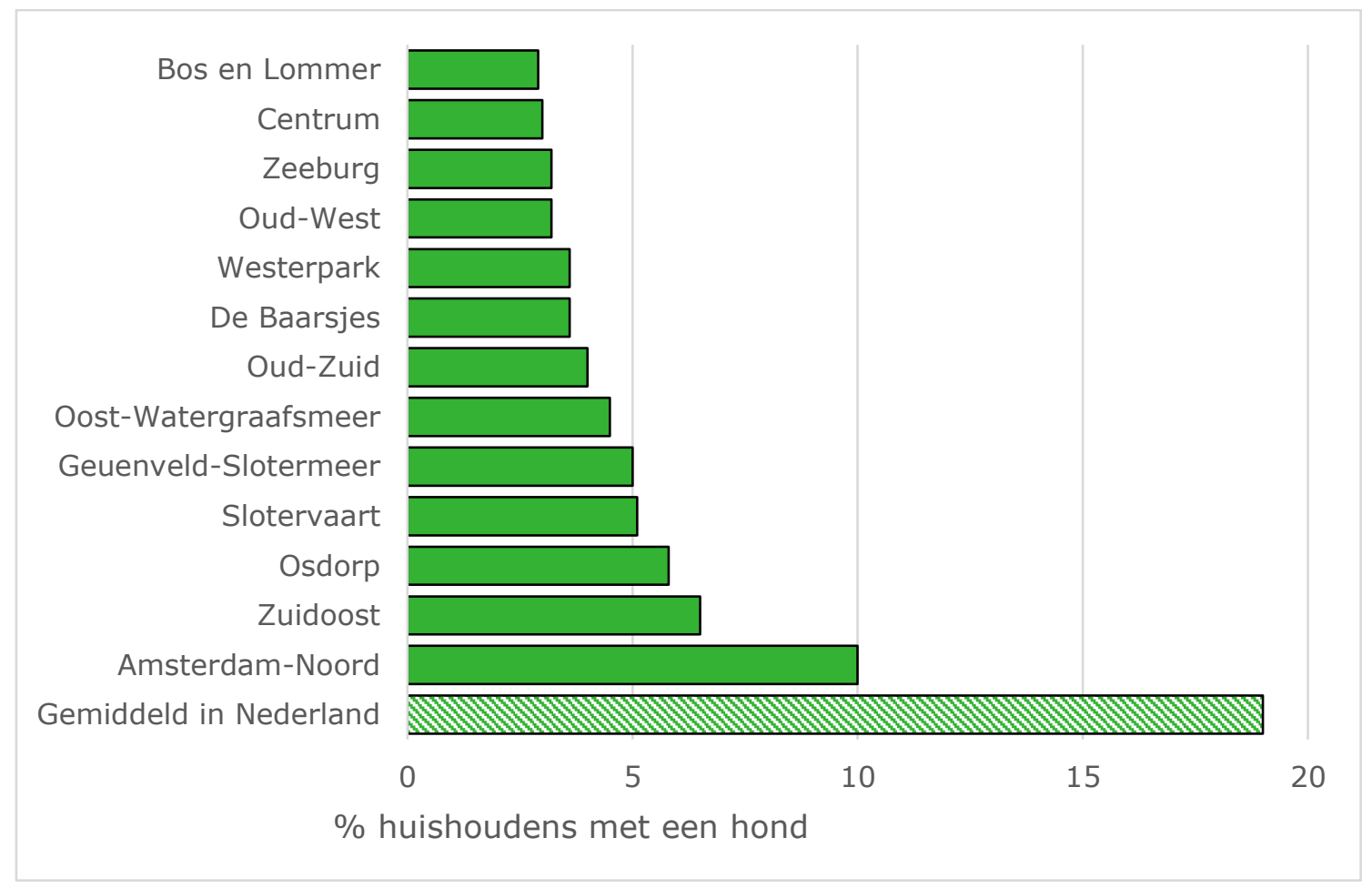

Figuur 1 Het percentage huishoudens met een hond (groen) in de stadsdelen van Amsterdam in 2008 (Gemeente Amsterdam, 2008b) ten opzichte van het percentage huishoudens met een hond gemiddeld in Nederland volgens Dibevo/NVG (groen gearceerd) (Dibevo en NVG, 2017)

In 2015 werd in totaal een vergelijkbaar bedrag aan hondenbelasting geïnd als in 2008. Het hondenbestand vertoont in die jaren echter een dalende lijn vanwege een wijzigende samenstelling van de huishoudens in Amsterdam. Meer alleenstaanden en een toename van het aantal burgers met een niet-Westerse achtergrond doen de motivatie om een hond te houden afnemen ${ }^{7}$. Met ingang van 1 januari 2016 is in de gemeente Amsterdam de hondenbelasting afgeschaft (Gemeente Amsterdam, 2016b).

De schatting van het aantal honden in Amsterdam komt op basis van bovenstaande (gemeentelijke) stukken uit tussen de 27.000 en 38.000 honden. Naar schatting heeft daarmee 6 tot $9 \%$ van de Amsterdamse huishoudens een hond.

\footnotetext{
${ }^{7}$ Beantwoording schriftelijke vragen van raadslid de heer J.F.W. van Lammeren van 3 november 2010 inzake hondenbelasting.
} 


\section{Aard en omvang van bijtincidenten op basis van literatuur}

\subsection{In Nederland}

Een in 2007 in samenwerking met TNS NIPO uitgevoerd onderzoek onder een representatieve steekproef van de Nederlandse bevolking geeft voor het eerst een vrij volledig beeld van de aard en omvang van bijtincidenten in Nederland (Cornelissen and Hopster, 2008); Tabel 1). Uit dat onderzoek blijkt een incidentie van 917 bijtincidenten per 100.000 inwoners en een totaal aantal bijtincidenten van 150.000 per jaar. Van deze incidenten resulteerde een vijfde in een ernstige verwonding, bij een derde van de bijtincidenten werd medische hulp gezocht en per 100.000 inwoners werden 1,8 slachtoffers opgenomen in het ziekenhuis.

In de periode 2001 t/m 2006 meldden zich in Nederland naar schatting jaarlijks tussen de ca. 29.000 en 53.000 mensen bij de huisarts om zich voor een hondenbeet te laten behandelen (Commissie van Wijzen, 2008). Volgens het jaarverslag van de Stichting inschrijving op naam (ION, 2015) staat meer dan $97.5 \%$ van het aantal inwoners in ons land als patiënt bij een huisarts ingeschreven. Aangenomen dat dit ook in 2006 het geval was, komt de incidentie in 2006 daarmee neer op 324 huisartsbezoeken ( \pm 30 ) per 100.000 inwoners. Vier van de vijf via vragenlijsten achterhaalde hond-mens incidenten die niet leidden tot een ernstige verwonding zijn waarschijnlijk niet bij de politie geregistreerd.

In tabel 1 staat een overzicht van de gevonden bijtincidentieschattingen in Nederland en in Amsterdam. In Nederland overleden in de periode 1996 tot en met 2011 jaarlijks gemiddeld 5.347 personen als gevolg van een niet-natuurlijke doodsoorzaak (CBS). Bij gemiddeld 1,3 personen was dit toe te schrijven aan een beet of aanval door een hond (code W54). Strikt genomen zouden hier volgens het CBS ook gevallen in kunnen voorkomen die niet gebeten zijn, maar door een hond bestormd zijn, en dan ongelukkig terecht gekomen zijn bij een val of iets dergelijks. Opmerkelijk is dat in diezelfde periode jaarlijks gemiddeld 46 personen overleden als gevolg van beten of aanvallen door andere zoogdieren (code W55). Het is niet ondenkbaar dat het hier vooral ongelukken in de veehouderij betreft. 
Tabel 1 Overzicht van bijtincidenten in Nederland en in Amsterdam naar ernst van de gevolgen/registratiespoor ${ }^{8}$

\begin{tabular}{|c|c|c|c|c|c|c|}
\hline \multirow{2}{*}{$\begin{array}{l}\text { Bijtincidenten hond-mens / } \\
\text { meldingen }\end{array}$} & \multirow[t]{2}{*}{ Herkomst cijfers } & \multirow[t]{2}{*}{ Bron } & \multirow{2}{*}{$\begin{array}{l}\text { Land/ } \\
\text { Gemeente }\end{array}$} & \multirow[t]{2}{*}{ Periode } & \multicolumn{2}{|c|}{ Aantal slachtoffers en/of meldingen } \\
\hline & & & & & Per jaar & Per 100.000 inwoners \\
\hline Alle bijtincidenten & NIPO-Enquête & Cornelissen \& Hopster, 2008 & Nederland & Nov. 2006 t/m Okt. 2007 & 150.000 & 917 \\
\hline Huisartsenbezoek & NIVEL Zorgregistraties eerste lijn & Cornelissen \& Hopster, 2008 & Nederland & 2006 & 53.000 & 325 \\
\hline SEH bezoek & Consument en Veiligheid, LIS & Cornelissen \& Hopster, 2008 & Nederland & $2002-2006$ & 6.900 & 43 \\
\hline Ziekenhuisopname & Consument en Veiligheid, LMR & Cornelissen \& Hopster, 2008 & Nederland & 2001-2005 & 230 & 1,4 \\
\hline Overlijden & Doodsoorzaken statistiek & CBS & Nederland & $1982-1992$ & 1,1 & 0,0074 \\
\hline Overlijden & Doodsoorzaken statistiek & CBS & Nederland & $1992-2008$ & 1,2 & 0,0074 \\
\hline Overlijden & Doodsoorzaken statistiek & CBS & Nederland & $2009-2016$ & 0,5 & 0,0023 \\
\hline SEH bezoek & LIS systeem & VeiligheidNL & Nederland & 2010 & 2.600 & 15,4 \\
\hline SEH bezoek & LIS systeem & VeiligheidNL & Amsterdam & 2010 & 153 & $19,9^{6}$ \\
\hline Ziekenhuisopname & LIS systeem & VeiligheidNL & Nederland & 2010 & 200 & 1,0 \\
\hline Ziekenhuisopname & LIS systeem & VeiligheidNL & Amsterdam & 2010 & 6 & $0,78^{6}$ \\
\hline Huisartsen bezoek & HIS systeem & NIVEL Zorgregistraties eerste lijn & Nederland & 2015 & 77.700 & 460 \\
\hline Huisartsen bezoek & HIS systeem & NIVEL Zorgregistraties eerste lijn & Amsterdam & 2015 & 2.500 & 300 \\
\hline SEH bezoek & LIS systeem & VeiligheidNL & Nederland & 2015 & 2.600 & 15,4 \\
\hline SEH bezoek & LIS systeem & VeiligheidNL & Amsterdam & 2015 & 75 & $9,1^{9}$ \\
\hline Ziekenhuisopname & LIS systeem & VeiligheidNL & Nederland & 2015 & 100 & 0,8 \\
\hline Ziekenhuisopname & LIS systeem & VeiligheidNL & Amsterdam & 2015 & 1 & $0,12^{9}$ \\
\hline
\end{tabular}

\footnotetext{
${ }^{8}$ De gegevens van 2010, 2015 en 2016 zijn omwille van het overzicht in deze tabel opgenomen, maar worden toegelicht in hoofdstukken 5 en 6.

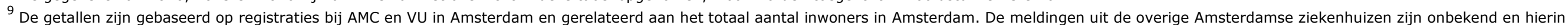
niet opgenomen.
} 


\subsection{In andere landen}

Schattingen van hond-mens bijtincidenten in het buitenland lopen erg uiteen. Het kan niet worden uitgesloten dat de manier waarop gegevens zijn verzameld hier een rol in speelt. Uit Amerikaans onderzoek komen hogere hond-mens incidentieschattingen dan uit het onderzoek in Nederland (Cornelissen and Hopster, 2008). Op basis van een random telefonische survey in de periode van 2000-2003 werden in de Verenigde Staten jaarlijks 1580 bijtincidenten per 100.000 inwoners geschat (Gilchrist et al., 2008) waarvan bij 309 (19\%) medische hulp werd ingeroepen. Uit soortgelijk Amerikaans onderzoek in 1994 kwam een bijtincidentie van 1708 per 100.000 inwoners naar voren waarvan 288 slachtoffers (17\%) een beroep deden op medische hulp (Sacks, Kresnow and Houston, 1996). Hoff et al. (2005) presenteerde zijn resultaten op een andere manier door te stellen dat één op de twee Amerikanen in hun leven gebeten wordt door een hond.

Fatale bijtincidenten kwamen in Amerika tussen 1979 en 2005 volgens Langley (2009) gemiddeld 19 keer per jaar voor, wat overeenkomt met 0,0071 per 100.000 inwoners. Dit is vergelijkbaar met de situatie in Nederland tussen 1995 en 2006 en ongeveer dubbel zo hoog als in de periode 2010-2016 (Cornelissen and Hopster, 2008; CBS Statline, 2017). Bradley (2014) geeft in een beleidsadvies aan dat in de Verenigde Staten van de 92.000 personen die overleden als gevolg van een niet-natuurlijke doodsoorzaak, dit in 1 geval veroorzaakt werd door een (fataal) bijtincident.

Onderzoek in Ierland wijst uit dat er per 100.000 inwoners sprake is van 5-6 bijtincidenten met ziekenhuisopname als gevolg (Ó Súilleabháin \& Doherty, 2015). In Australië leidden in 1995 per 100.000 inwoners bijna 8 bijtincidenten tot de opname in het ziekenhuis (Ozanne-Smith et al., 2001). Zwitsers onderzoek komt uit op 180 bijtincidenten per 100.000 inwoners per jaar waarvoor medische behandeling nodig was (75\% behandeling bij een huisarts en $25 \%$ behandeling in ziekenhuis) en 3,6 bijtincidenten per 100.000 inwoners waarvoor ziekenhuisopname nodig was (Horisberger et al., 2004). Horisberger et al. (2004) stelden op basis van de literatuur vast dat de bijtincidentie varieert tussen 73 tot 1800 per 100.000 inwoners en dat per 100.000 inwoners er jaarlijks 2,3 tot 5,2 slachtoffers in het ziekenhuis worden opgenomen.

In Tabel 2 wordt een samenvatting gegeven van de aard en omvang van bijtincidenten in het buitenland op basis van de literatuur. Ten opzichte van genoemde landen lijkt het aantal ziekenhuisopnames als gevolg van een hondenbeet in Nederland met 1,8 per 100.000 inwoners relatief laag (Cornelissen \& Hopster, 2008). 
Tabel 2 Overzicht van bijtincidenten in andere landen naar ernst van de gevolgen/registratiespoor

\begin{tabular}{|c|c|c|c|c|c|c|}
\hline \multirow{2}{*}{$\begin{array}{l}\text { Bijtincidenten hond-mens } \\
\text { / meldingen }\end{array}$} & \multirow[t]{2}{*}{ Herkomst cijfers } & \multirow[t]{2}{*}{ Bron } & \multirow[t]{2}{*}{ Land/stad } & \multirow[t]{2}{*}{ Periode } & \multicolumn{2}{|c|}{ Aantal slachtoffers en/of meldingen } \\
\hline & & & & & Per jaar & Per 100.000 inwoners \\
\hline Alle bijtincidenten & Random survey & Gilchrist et al. 2008 & Verenigde Staten & $2001-2003$ & 4.521 .300 & 1580 \\
\hline Alle bijtincidenten & National telephone survey & Sacks et al., 1996 & Verenigde Staten & 1994 & 4.494 .083 & 1800 \\
\hline Medische hulp & National telephone survey & Sacks et al., 1996 & Verenigde Staten & 1994 & 756.701 & 300 \\
\hline Medische hulp & Random survey & Gilchrist et al. 2008 & Verenigde Staten & 2001-2003 & 885.000 & 309 \\
\hline SEH bezoek & Hospital data & Thompson, 1997 & Adelaide & jan 1990 - juli 1993 & & 73 \\
\hline SEH bezoek & $\begin{array}{l}\text { National Hospital Ambulatory Medical } \\
\text { Care Survey }\end{array}$ & Weiss et al., 1998 & Verenigde Staten & 1992-1994 & & 129 \\
\hline SEH-bezoek & & Thomas and Voss, 1991 & Engeland (Salisbury) & & & 150 \\
\hline SEH-bezoek & & Ozanne-Smith et al., 2001 & Dunedin & $1989-1990$ & & 175 \\
\hline SEH-bezoek & & Thomas and Banks, 1990 & Engeland (Thanet) & & & 300 \\
\hline Ziekenhuisopname & & Ozanne-Smith et al., 2001 & Canada & 1994-1996 & & 2,6 \\
\hline Ziekenhuisopname & & Ozanne-Smith et al., 2001 & Nieuw Zeeland & 1988 & & 4,8 \\
\hline Ziekenhuisopname & & Ó Súilleabháin \& Doherty, 2015 & Ierland & $1998-2013$ & 3.164 (totaal) & 4,98 \\
\hline Ziekenhuisopname & $\begin{array}{l}\text { Australian Institute of Health and } \\
\text { Welfare. }\end{array}$ & Rajshekar et al., 2017 & Australië & 2001-2013 & 2601 & 12,39 \\
\hline Overlijden & & Ozanne-Smith et al., 2001 & Australie & $1995 / 1996$ & & 0,004 \\
\hline Overlijden & & Ozanne-Smith et al., 2001 & Canada & 1987-1997 & & 0,007 \\
\hline Overlijden & Mortality files & Langley, 2009 & Verenigde Staten & $1979-2005$ & 19 & 0,007 \\
\hline
\end{tabular}




\section{$4 \quad$ Risicofactoren voor een bijtincident zoals aangegeven in de literatuur}

Bijtincidenten zijn een reflectie van de mens-hond interactie (Keuster \& Butcher, 2008) of van de interactie van de hond met een ander dier. De factoren die bijdragen aan het ontstaan van een bijtincident zijn in drie, deels overlappende, verzamelingen onder te brengen: de hond die aanvalt, de houder en/of begeleider van deze hond en de context waarin het incident (Raad voor Dierenaangelegenheden, 2017).

\subsection{Hond}

Een hond kan verschillende beweegredenen hebben om agressie te vertonen of te bijten (Lockwood, 2016). Volgens Borchelt (1983) zijn er voor een hond acht beweegredenen om agressief gedrag te vertonen: angst, dominantie, bezit, bescherming, predatie, straffen, pijn en intraspecifieke agressie. Heath benoemt in Honey (2017) juist acht, deels andere, emotionele toestanden als motivatie voor verschillende gedragingen: frustratie, verlangen, angst, sociaal spel, lust, zorg, paniek (verdriet) en pijn. Blackshaw (1991) tenslotte noemt negen verschillende vormen van agressie: competitief, seksueel (tussen reuen), territoriaal, predatie, pijn geïnduceerd, angst geïnduceerd, maternaal, aangeleerd en dominantie agressie.

Iedere hond kan bijten ongeacht ras, leeftijd of sekse (AVSAB, 2014; Overall \& Love, 2001). Agressie bij honden die resulteert in bijtgedrag wordt door mensen meestal gezien als niet gewenst gedrag. Agressie bestaat uit gedragselementen die door in- en uitwendige factoren (motivatie, prikkels) worden veroorzaakt. Voordat een hond tot bijten overgaat vertoont deze (meestal) gedrag dat aangeeft dat de hond de situatie als bedreigend ervaart zoals de nekharen opzetten (Honey, 2017). Onder agressie vallen ook waarschuwingssignalen als blaffen, grommen en tanden ontbloten. De opeenvolging van steeds sterkere signalen van dreiging en verweer wordt de agressieladder genoemd (Shepherd, 2002). Honden grommen en blaffen daarnaast in spelsituaties (Bálint et al., 2013).

Ernstige vormen van agressie zijn uitvallen, happen en daadwerkelijk bijten.

Een agressieve reactie op bepaalde prikkels is voor de hond in het algemeen niet abnormaal. Agressie kan zich echter ontwikkelen tot een serieus probleem (van den Berg et al., 2006). Niet alleen vanwege onveiligheid voor mens of dier maar ook als een welzijnsprobleem voor de hond zelf. Dergelijke honden worden noodzakelijkerwijs vaker geïsoleerd gehouden waardoor bepaald gedrag niet meer kan worden uitgevoerd (sociale interactie, exploratie) en de kans groter wordt dat (na herhaling) de hond wordt afgestaan of uiteindelijke wordt geëuthanaseerd (Wright, 1996; Voith, 2009).

Vanouds werden hondenrassen gefokt om voor de mens een bepaalde taak te vervullen. Hierbij vond, en vindt, selectie plaats op gedragspatronen en op uiterlijke kenmerken. Gedragspatronen worden uitgevoerd volgens bepaalde wetmatigheden die bepalen wanneer, waar en hoe ze tot uitdrukking komen (Lord, Schneider and Coppinger, 2016). Borchelt (1983) benoemt prooiagressie (predatie) als een vorm van agressie naar mensen. Prooiagressie is opgebouwd uit opeenvolgende elementen als: de oriëntatie houding (kop boven de schouders, oren omhoog en de ogen en neus gefocust op de mogelijke prooi), gevolgd door het stalken van de prooi met de ogen (lagere kophouding, oren omlaag of naar voren en ogen en neus gefocust op de potentiele prooi), besluipen van de prooi (waarbij de poten gebogen zijn tijdens beweging of het stilstaan), achtervolgen van de prooi, het grijpen en vastbijten van de prooi, het dood bijten van de prooi en het verscheuren van de prooi (Lord, Schneider and Coppinger, 2016). Lafarge (2016) geeft aan dat belangrijke verschillen in gedrag bij prooiagressie ten opzichte van andere vormen van agressie zijn dat:

- De hond geen afstand houdt maar juist probeert de prooi zo dicht mogelijk te benaderen zonder deze te verstoren of angst in te boezemen;

- De hond daarom minder gedifferentieerde of zelfs in het geheel geen waarschuwingssignalen afgeeft;

- $\quad$ Predatie vooral lijkt te worden aangestuurd vanuit de laterale hypothalamus (hongergevoel) terwijl andere vormen van agressie juist worden aangestuurd vanuit de amygdala (emoties). 
Specifieke elementen uit het complexe gedragsrepertoire van de voorouders van de hond zijn in specifieke rassen uitvergroot, passend bij de functie die het ras voor de mens vervult. Zo zijn vee

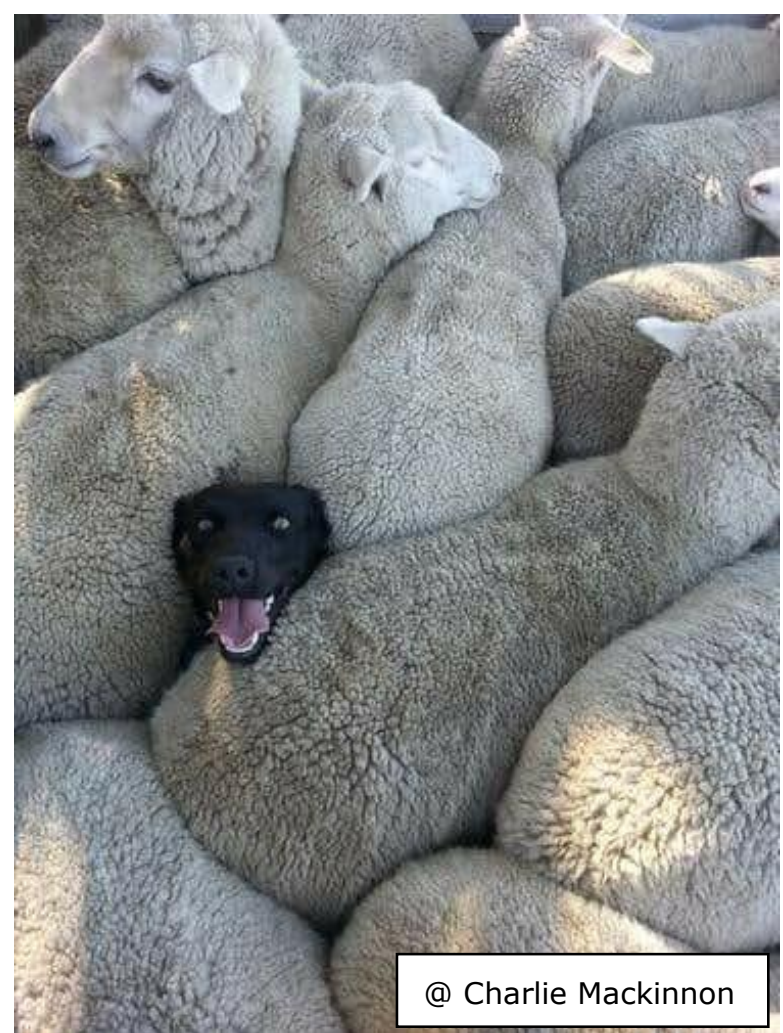
drijvende honden geselecteerd op het gebruik van een gecoördineerde reeks van bewegingen, overeenkomstig het jachtgedrag van hun voorouders. Sledehonden en waakhonden zijn veel minder gespecialiseerd in dergelijk gedrag. De intensiteit van de verschillende gedragspatronen verschilt ook tussen vee drijvende rassen waardoor bepaalde rassen makkelijker te trainen zijn dan andere om bepaald gedrag juist wel of juist niet te vertonen. De omstandigheden waarin de aangeleerde gedragspatronen uitgevoerd worden, worden grotendeels bepaald door vroege ervaringen (kritische periode).

Zo zal een Bordercollie die is opgegroeid tussen de schapen (zie foto) later niet door deze diersoort worden getriggerd om de gedragspatronen 'met de ogen stalken besluipen - achtervolgen' uit te voeren (Lord, Schneider and Coppinger, 2016).

Ook Lafarge (2016) geeft aan dat goede socialisatie op jonge leeftijd in de 'gewenste uiteindelijke gebruiksomgeving' het vertonen van prooiagressie voorkomt.

Agressie naar mensen is een complex fenomeen waarachter meerdere vormen van agressie kunnen schuilgaan en waarbij diverse risicofactoren een rol spelen (Wright, 1996; Lafarge, 2016). Hierna wordt een aantal van deze factoren besproken.

\subsubsection{Socialisatie en training}

In het algemeen is gedrag niet alleen een product van de genen maar zijn andere factoren zoals socialisatie en training medebepalend (Van den Berg, 2016). Ook Wilsson (2016) benoemt in 'Nature and nurture?' de invloed van genen, socialisatie en (op individu afgestemde) training op gedrag. De kritische socialisatie periode begint als de pup ongeveer vier weken oud is. Rond de achtste week begint de periode waarin de pup onbekende dingen gaat mijden. De lengte van de periode waarin socialisatie plaats kan vinden verschilt tussen rassen (Lord, Schneider and Coppinger, 2016). In vergelijkbare situaties verschilt de 'bijtdrempel' tussen honden (van den Berg et al., 2006).

Genetics and training of dogs cannot be treated as 2 separate parts. To have the requested phenotype mature as expected, within limits set by the genotype, a dog needs to be raised and trained in a correct way to develop the desired traits. This training, in turn, must be adapted to the individual dog's personality. uit: Wilsson (2016) Nature and nurture? How different conditions affect the behavior of dogs
Verschillen worden veroorzaakt door het karakter en de opvoeding (socialisatie periode en erna) (McMillan, 2017).

Positieve training draagt bij aan de vermindering van ongewenst gedrag (Blackwell et al., 2008). Heath stelt in Honey (2017) dat het afstraffen van gedrag laag op de agressieladder, de kans vergroot dat de hond deze waarschuwingen de volgende keer achterwege laat en meteen zal bijten. Mills et al. (2014) geven ook aan dat straffen kan leiden tot het onderdrukken van waarschuwingssignalen door de hond waardoor bijtgedrag onvoorspelbaar wordt. Bradshaw \& Rooney (2016) geven aan dat als een hond (herhaaldelijk) gestraft wordt door de eigenaar, waarbij de hond de associatie tussen zijn gedrag en de straf niet kan leggen, deze zijn gedrag gaat

aanpassen naar een strategie die succesvol is om de straf te ontlopen. Die strategie kan bijten zijn. Arhant et al. (2010a) vonden dat vooral kleine rassen meer onrust en angst gaan vertonen als de eigenaar vaker straft. Sacks et al. (2000) beweren dat alle honden, ongeacht het ras, gevaarlijk kunnen worden wanneer ze daar specifiek voor worden gefokt of getraind. 


\subsubsection{Leeftijd van de hond}

Wright (1996) beschrijft dat uit bepaalde studies blijkt dat honden jonger dan 5 jaar de meeste bijtincidenten veroorzaken (50-70\%). Bij ernstige bijtincidenten blijken vaak honden tussen 3 en 4 jaar oud betrokken. Verder is er een indicatie dat jonge honden, tussen 6 en 11 maanden, het vaakst (aantal keren per jaar) lijken te bijten. Terwijl andere studies juist aangeven dat er geen verschil is in het aantal bijtincidenten tussen leeftijdsgroepen. Messam et al. (2013) maken in hun studie onderscheid tussen bijten tijdens het spelen (spelbijten) en bijten buiten een spel situatie. Spelbijten komt vooral voor rond de leeftijd van 3 maanden en het risico neemt sterk af gedurende het eerste levensjaar. Het risico op bijten neemt vooral toe in het eerste levensjaar tot ongeveer het derde levensjaar. Kubinyi et al. (2009) geven aan dat honden rustiger worden naarmate ze ouder worden. Mede doordat 'bijten' in verschillende studies verschillend wordt gedefinieerd, ontbreekt het aan generiek inzicht in de rol van leeftijd van de hond bij het optreden van bijtincidenten die in aard en ernst zeer kunnen verschillen.

\subsubsection{Geslacht van de hond}

Een bijtincident waarbij de mens het slachtoffer is, lijkt vaker veroorzaakt te worden door reuen dan door teven. Uit een review van Wright (1996) komt dat reuen verantwoordelijk zijn voor 70-76\% van de bijtincidenten en voor $80 \%$ van de ernstige bijtincidenten. Voor de fatale bijtincidenten lijken ook vooral de reuen verantwoordelijk te zijn. Ook in de review van Lockwood (2016) staat dat uit veel studies blijkt dat reuen hogere niveaus van agressief gedrag vertonen en ernstige bijtincidenten voornamelijk door reuen worden veroorzaakt.

Agressie naar de eigenaar is volgens de review van Serpell (2016b) een veel door trainers en gedragsexperts genoemd gedragsprobleem en lijkt meer voor te komen bij intacte reuen en geneutraliseerde teven. Er zijn echter ook studies die dit tegenspreken. Farhoody \& Zink (2010) vonden dat geneutraliseerde reuen juist een hogere agressie score hadden dan niet geneutraliseerde reuen ongeacht op welke leeftijd neutralisatie had plaats gevonden. Kaufmann et al. (2017) vonden een trend dat geneutraliseerde reuen in stressvolle situaties emotioneel instabieler waren dan niet geneutraliseerde reuen. Bovendien bleken ze meer geneigd om agressief en angstig gedrag te vertonen. Op basis van een review van 5 studies naar neutralisatie en bijtincidenten concluderen D'Onise et al. (2017) dat, alhoewel de studies geen causale verbanden aan (kunnen) tonen maar alleen associaties, er consistent bewijs is dat verplichte neutralisatie zal bijdragen aan vermindering van het aantal bijtincidenten. De auteurs geven echter aan dat deze maatregel vergezeld moet gaan van goede voorlichting.

Lockwood (2016) betoogt dat de gevonden samenhang met de neutralisatie status, in ieder geval in de Verenigde Staten, waarschijnlijk veroorzaakt wordt door andere factoren. Deze hangen samen met de mate waarin de eigenaar zich verantwoordelijk toont voor het gedrag van zijn/haar hond.

Zawistowski \& Reid (2016) geven vanuit hun review aan dat neutraliseren van honden die agressief gedrag vertonen, in het algemeen niet als preventieve maatregel gezien moet worden. Zij pleiten voor een complete en zorgvuldige evaluatie van iedere individuele hond die agressief gedrag vertoont, inclusief een diergeneeskundige beoordeling. Via maatwerk dient vervolgens een plan te worden opgesteld om ongewenst gedrag te corrigeren en de hond veilig te kunnen hanteren.

Samenvattend komt uit de onderzochte literatuur dat reuen vaker bijtincidenten lijken te veroorzaken dan teven, maar een éénduidige conclusie over een al of niet lagere kans op een bijtincident bij geneutraliseerde honden is niet mogelijk.

\subsubsection{Grootte, bouw en vorm van de hond}

De ernst van een bijtincident is onder meer afhankelijk van de kracht die een hond tijdens het bijten uitoefent op het slachtoffer. De schade die een hond bij het bijten kan aanrichten neemt toe met de kracht die ze met hun kaken kunnen zetten. Door middel van elektrostimulatie activeerden Ellis et al. (2008) de kaakspieren van gesedeerde honden (buiten bewustzijn) die onder andere verschilden in schedelvorm en lichaamsgewicht. Bij maximale stimulatie werd ook de bijtkracht gemeten. Zij stelden vast dat de verhoudingen tussen respectievelijk snuitlengte en schedellengte $(\mathrm{SnL} / \mathrm{SL})$ en tussen schedelbreedte en schedellengte (SW/SL) in de regressievergelijking die de bijtkracht het beste schatte $(R 2=0,93)$, anders dan verwacht, niet voor kwamen. SnL/SL kwam in geen enkele van de 23 getoetste regressievergelijkingen voor en SW/SL kwam slechts in één regressievergelijking voor, maar anders dan verwacht verminderde deze juist de bijtkracht. Met andere woorden, de verhoudingen tussen snuitlengte en schedellengte of schedelbreedte en schedellengte hebben nauwelijks tot geen 
invloed op de bijtkracht volgens Ellis et al. (2008). De auteurs geven aan dat met name het formaat van de hond de bijtkracht verklaart. Ook uit een later onderzoek van dezelfde eerste auteur, waarin de bijtkracht werd gemodelleerd vanuit de dimensies van de botstructuur van de kaken, komt dat bijtkracht voornamelijk wordt verklaard door het formaat van de hond (Ellis et al., 2009). Uit het theoretisch modelonderzoek van Ellis et al. (2009) komt echter nog wel de suggestie dat er een relatie is tussen vorm van de schedel en formaat van de hond (bij medium en grotere honden) waarbij de brachycefale schedelvorm de grootste bijtkracht heeft. Graeves hypothese in 1985 was dat de absolute hoeveelheid kaakspieren en de bijtkracht samenhangen (Greaves, 1985). Of en hoe de hoeveelheid kaakspieren samenhangt met het formaat van de hond en met de vorm van de kop is onbekend.

Gedrags- en uiterlijke kenmerken hangen vaak samen. McGreevy et al. (2013) vonden bij honden bijvoorbeeld een positief verband tussen schedelbreedte en hond-gerichte agressie, een negatief verband tussen grootte en baas-gerichte agressie en een positief verband tussen lichaamsgewicht en vreemdeling-gerichte agressie. Gazzano et al. (2015) vonden dat honden met een korte schedel minder naar de baas keken dan honden met een lange schedel. Ook duurde het bij het niet weten uit te voeren van een taak, bij kortschedelige honden langer voordat deze naar hun baas keken. Hieruit concluderen zij dat hier sprake kan zijn van een minder goede trainbaarheid van honden met een korte schedel.

Naast morfologische raskenmerken spelen ook andere zaken een rol zoals de manier waarop mensen omgaan met een bepaald type hond. Zo beweren Arhant et al. (2010) op basis van verschillende studies dat eigenaren van kleine honden deze vaak minder goed trainen en minder consequent zijn in het voorkomen van ongewenst gedrag. Hierdoor worden kleine honden vaker als ongehoorzamer, agressiever, meer opgewonden en angstiger beschouwd.

\subsubsection{Ras of type hond}

De huidige rassen vertonen veel variatie in morfologie, genetica en gedrag, versterkt door een lange periode van selectie (Svartberg, 2006). Zo verschillen rassen onder andere in de manier waarop ze met de mens communiceren (Jakovcevic et al., 2010). Tussen rassen bestaan volgens sommige onderzoekers ook verschillen in persoonlijkheidskenmerken (Miklósi et al., 2014), terwijl andere onderzoekers dit juist niet konden aantonen (Svartberg et al., 2005). Kovács et al. (2016) toonden tussen (twee) rassen een verschil aan in reactie op het toedienen van oxytocine. Het hormoon oxytocine speelt een belangrijke rol in de affectieve relatie tussen hond en mens. Na toediening van oxytocine reageerden de meer op coöperatieve vermogens gefokte Bordercollies in bedreigende en uitdagende situaties met een meer sociale respons dan de Siberische husky's, die gefokt zijn op zelfstandigheid. Ook de trainbaarheid verschilt tussen rassen (Serpell and Hsu, 2005; zie figuur 2).

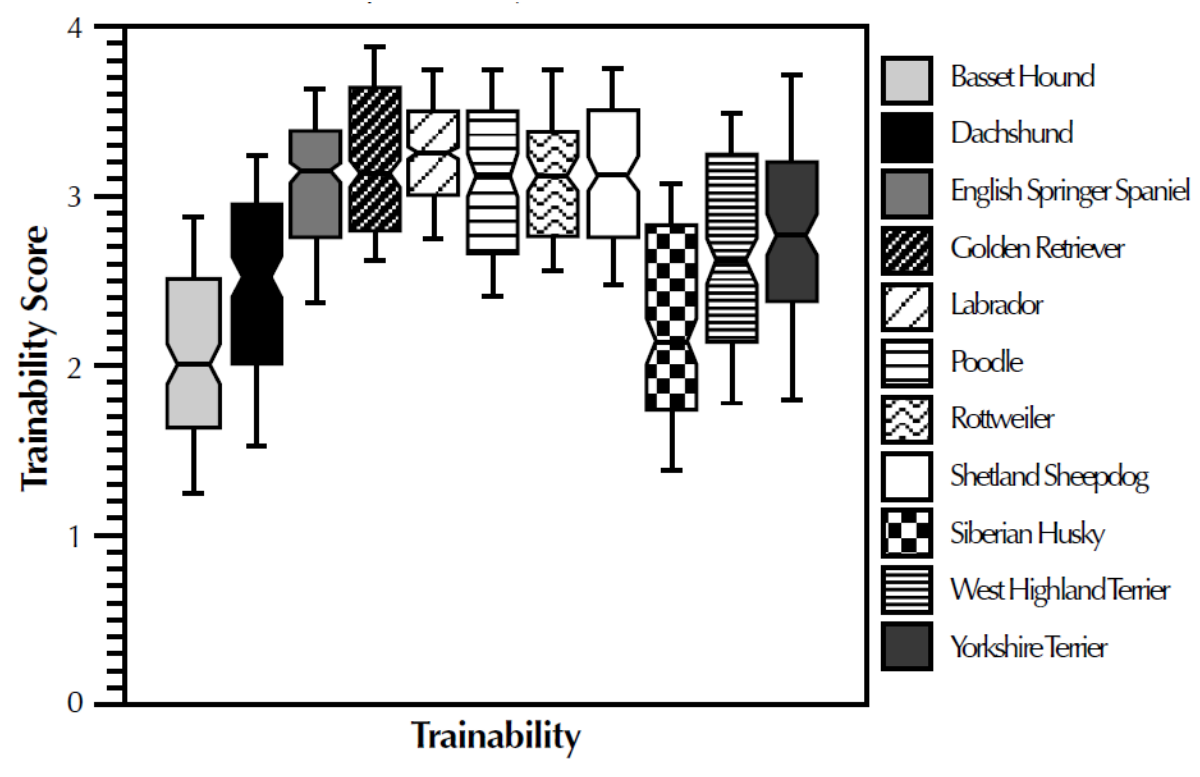

Figuur 2 Trainbaarheid van 11 verschillende rassen (1.563 honden) zoals aangegeven door de eigenaren op basis van een gestandaardiseerde vragenlijst (C-BARQ, bron: Serpell and Hsu, 2005) 
Volgens Van den Berg (2016) wordt het gedrag van honden gecontroleerd door een kleiner aantal loci dan het menselijk gedrag maar is het nog steeds een complex kenmerk dat veel genen en gen-gen of gen-milieu-interacties omvat. Volgens de auteur staat het onderzoek naar welke genen verantwoordelijk zijn voor welk gedrag nog in de kinderschoenen.

Waak- en vechthonden werden vroeger vooral gehouden om de mens en zijn eigendommen te beschermen. Volgens Lockwood (2016) komen de problemen die geassocieerd worden met agressief gedrag voort uit de specifieke aandacht voor agressie in het fokdoel. In bepaalde hondenrassen werd juist gestimuleerd dat agressieve ouders - naar soortgenoten en/of naar andere dieren - ingezet werden om de volgende generatie voort te brengen. Rassen als bijvoorbeeld de Rottweiler, de Dobermann en de Duitse herder werden geselecteerd op agressie tegen vreemden. Een ras als bijvoorbeeld de Amerikaanse bullterriër werd gefokt op voldoende agressie om te willen vechten (Van den Berg, 2016). In diverse studies is de associatie tussen ras en bijtincidenten gesuggereerd (Svartberg \& Forkman, 2002; Duffy et al., 2008; Mehrkam \& Wynne, 2014). Cornelissen \& Hopster (2008) berekenden een bijtindex op basis van het aantal honden van een bepaald ras dat was betrokken bij een bijtincident in verhouding tot het totaal aantal aanwezige honden van dat ras. Elf rassen bleken relatief meer en 11 rassen bleken relatief minder bij bijtincidenten te zijn betrokken dan op grond van de aantallen waarin honden van deze rassen worden gehouden, werd verwacht. In andere studies werd juist de rasgebondenheid van agressie genuanceerd (Schalke et al., 2008; Martínez et al., 2011).

Uit analyse van bijtincidenten met dodelijke afloop in de Verenigde Staten van 1979 tot 1999 bleek dat Pitbull type honden en Rottweilers in meer dan de helft van de incidenten als agressor werden aangemerkt (Sacks et al., 2000). De reden dat vooral dit type honden bij dodelijke incidenten betrokken is, is mogelijk ook de grotere schade die een dergelijk type hond kan aanrichten. Ook Bini et al. (2011) geeft aan dat honden van het type Pitbull bij een bijtincident vaker meer schade toebrengen. Daarentegen vonden Cornelissen en Hopster (2008) in hun analyse van politiedossiers over bijtincidenten geen aanwijzingen dat Bulterriërs ernstiger verwondingen veroorzaakten dan andere honden. Ook een Ierse vergelijking van letselschade als gevolg van beten van zogenaamde 'legislated breeds' (Duitse herder, Rottweiler, Amerikaanse staffordshireterriër, Akita en Dobermann) en 'non-legislated breeds' liet geen verschil zien in de ernst van het letsel (Creedon and Ó Súilleabháin, 2017). Onderzoek van O’Brien et al. (2015) aan ziekenhuisdata in Californië wees echter uit dat ernstig letsel aan hoofd en nek bij een derde van de gevallen veroorzaakt was door 'Bulterriërs' en dat deze honden meer schade hadden toegebracht dan honden van andere rassen. De auteurs gaven hierbij aan dat wel rekening gehouden moet worden met andere (onbekende, niet in dit onderzoek meegenomen) factoren die naast ras een rol kunnen spelen zoals behandeling of training van de hond, hoeveel honden van een bepaald type voorkwam in de populatie en de sociale omgeving van de eigenaar. Dergelijke factoren kunnen verschillen tussen, maar ook binnen rassen versterken.

De review van Mehrkam \& Wynne (2014) bevestigt dat verschillen in gedrag tussen rassen bestaan maar dat ook binnen een ras tussen individuele honden grote verschillen in gedrag zijn te vinden. Sinds 2001 moeten ouderdieren binnen het Nederlandse stamboek voor Rottweilers geslaagd zijn voor de MAG test (Maatschappelijk Aanvaardbaar Gedrag test). Van der Borg et al. (2017) vonden geen verschil (op basis van beoordeling van gedrag door de eigenaren) in op gezinsleden gerichte agressie tussen Rottweilers met en zonder stamboom (relatief 1,37/p=0,542; zie tabel 3). Agressie, gericht op onbekenden was bij Rottweilers zonder stamboom bijna 2 x zo hoog en angst voor onbekenden bijna 4 $x$ zo hoog als bij Rottweilers met een stamboom (relatief resp. 0,51/p=0,056 en 0,24/p=0,040). Ook bij niet-sociale angst scoorden Rottweilers zonder een stamboom ca. 4 x zo hoog als Rottweilers met een stamboom (relatief $0,23 / p=0,002$ ). Hieruit kan geconcludeerd worden dat een dergelijke test voor fokdieren helpt om specifieke angst en agressie te verminderen.

Op de website van de Raad van Beheer (www.houdenvanhonden.nl) staat dat pups van ouders die geslaagd zijn voor de MAG-test, minder agressief gedrag vertonen en ook minder angstig zijn. De aanvullende regels voor een dergelijke test zijn er naast voor de Rottweiler ook voor de Amerikaanse staffordshireterriër, Argentijnse dog, Mastino napolitano en Fila brasileiro. 
Tabel 3 Prevalentie van zeven typen angst en agressie in groepen Rottweilers met en zonder stamboom in Nederland (van der Borg, Graat and Beerda, 2017)

\begin{tabular}{|c|c|c|c|c|c|c|c|}
\hline \multirow[t]{2}{*}{ Gedragscategorie } & \multirow[t]{2}{*}{ Stamboom } & \multicolumn{2}{|c|}{ Frequentie } & \multirow{2}{*}{$\begin{array}{c}\text { Prevalentie } \\
\%\end{array}$} & \multirow{2}{*}{$\begin{array}{l}\text { Relatief } \\
\text { t.o.v. } \\
\text { referentie }\end{array}$} & \multirow{2}{*}{$\begin{array}{l}\text { Betrouwbaar- } \\
\text { heidsinterval }\end{array}$} & \multirow{2}{*}{$\begin{array}{c}\text { Significantie } \\
\text { (P-waarde) }\end{array}$} \\
\hline & & $\mathrm{N}$ & $\%$ & & & & \\
\hline \multirow{2}{*}{$\begin{array}{l}\text { Agressie naar } \\
\text { onbekende } \\
\text { mensen }\end{array}$} & $\mathrm{Ja}$ & 295 & 47,6 & 6,4 & 0,51 & \multirow[t]{2}{*}{$0,26-1,02$} & \multirow[t]{2}{*}{0,056} \\
\hline & Nee & 325 & 52,4 & 16,0 & Ref. & & \\
\hline \multirow{2}{*}{$\begin{array}{l}\text { Agressie naar } \\
\text { gezinslid }\end{array}$} & $\mathrm{Ja}$ & 335 & 47,9 & 3,0 & 1,37 & \multirow[t]{2}{*}{$0,50-3,75$} & \multirow[t]{2}{*}{0,542} \\
\hline & Nee & 365 & 52,1 & 2,7 & Ref. & & \\
\hline \multirow{2}{*}{$\begin{array}{l}\text { Angst/agressie } \\
\text { naar onbekende } \\
\text { honden }\end{array}$} & $\mathrm{Ja}$ & 340 & 48,2 & 11,2 & 1,43 & \multirow{2}{*}{$0,81-2,53$} & \multirow[t]{2}{*}{0,219} \\
\hline & Nee & 366 & 51,8 & 14,8 & Ref. & & \\
\hline \multirow{2}{*}{$\begin{array}{l}\text { Agressie naar } \\
\text { gezinshond }\end{array}$} & Ja & 179 & 52,2 & 14,0 & 0,52 & \multirow[t]{2}{*}{$0,18-1,51$} & \multirow[t]{2}{*}{0,232} \\
\hline & Nee & 164 & 47,8 & 11,0 & Ref. & & \\
\hline \multirow{2}{*}{$\begin{array}{l}\text { Angst voor } \\
\text { onbekende } \\
\text { mensen }\end{array}$} & Ja & 321 & 48,0 & 0,9 & 0,24 & \multirow[t]{2}{*}{$0,06-0,94$} & \multirow[t]{2}{*}{0,040} \\
\hline & Nee & 348 & 52,0 & 4,3 & Ref. & & \\
\hline \multirow[t]{2}{*}{ Niet-sociale angst } & Ja & 320 & 47,9 & 2,2 & 0,23 & \multirow[t]{2}{*}{$0,09-0,58$} & \multirow[t]{2}{*}{0,002} \\
\hline & Nee & 348 & 52,1 & 7,8 & Ref. & & \\
\hline \multirow[t]{2}{*}{ Najagen } & $\mathrm{Ja}$ & 353 & 48,4 & 45,0 & 0,97 & \multirow[t]{2}{*}{$0,71-1,34$} & \multirow[t]{2}{*}{0,869} \\
\hline & Nee & 377 & 51,6 & 47,8 & Ref. & & \\
\hline
\end{tabular}

N.B. Op niet alle vragenlijsten waren alle vragen beantwoord.

Bradley (2014) geeft in een beleidsnotitie aan dat pogingen om met rasspecifieke wetgeving de kans op bijtletsel verder te verkleinen niet kunnen worden verdedigd op grond van enig wetenschappelijk bewijs. Zulke wetgeving is volgens Bradley derhalve arbitrair en elimineert bepaalde typen honden met stelselmatige willekeur zonder enig bewijs dat ze ooit een mens hebben beschadigd. Ook Kaspersson (2008) betoogt onder de titel 'On treating the symptoms and not the cause' dat er onvoldoende wetenschappelijke basis is voor rasspecifieke wetgeving. Zij concludeerde dat de focus te veel ligt bij ras/type en te weinig bij eigenaren en context en dat dit de mythevorming rond 'status dogs' en 'weapon dogs' in stand houdt. Tot een vergelijkbaar standpunt komen Arluke et al. (2017) op basis van een analyse van inhoud en taalgebruik van 156 artikelen over hondenbeten, geschreven door professionals uit de humane gezondheidszorg. Het onderzoek onthulde een patroon van verkeerde informatie over hondengedrag, over rassen en over mens-hond interactie die een negatief effect zou kunnen hebben op de manier waarop lezers honden en hun gedrag beoordelen. Verkeerde informatie omvatte feitelijke fouten, misinterpretaties, weglatingen, emotioneel geladen taal en overdrijvingen gebaseerd op verkeerd begrepen of onnauwkeurige statistieken of op vertrouwen op de interpretatie door derden van de mening van andere auteurs. Vormen van retoriek die werden aangetroffen waren generaliseren, catastroferen, demoniseren en negatieve vergelijking, onder andere met betrekking tot honden van het Pitbull type. Dat in de evaluatiestudie van Cornelissen en Hopster (2008) van de in beslag genomen honden van het type Pitbull slechts $7 \%$ bij een bijtincident betrokken was ondersteunt de stelling dat generalisatie en negatieve beeldvorming aan de orde zijn. Dit kan zijn weerslag hebben op de rassen en typen die als gevaarlijke honden worden beschouwd. Hierbij komt dat in slechts enkele decennia gedragskenmerken van een (lijn binnen een) ras kunnen veranderen (Svartberg, 2006) waardoor een lijst van gevaarlijke rassen met enige regelmaat zou moeten worden bijgesteld. 
Tabel 4 Relatief bijtrisico (BRI) voor enkele rassen waarbij rekening is gehouden met het aantal honden van dat ras in Nederland (ontleend aan Cornelissen and Hopster, 2008)

\begin{tabular}{|c|c|c|c|}
\hline \multirow[t]{2}{*}{ Rassen } & \multicolumn{2}{|c|}{$\begin{array}{c}\text { Alle bijtincidenten (opzettelijk en niet } \\
\text { opzettelijk) }\end{array}$} & \multirow[t]{2}{*}{$\begin{array}{l}\text { Significantie } \\
\text { (P-waarde) }\end{array}$} \\
\hline & $\begin{array}{l}\text { Honden, betrokken bij } \\
\text { bijtincidenten }\end{array}$ & Bijtrisico Index (BRI) & \\
\hline \multicolumn{4}{|c|}{$\begin{array}{l}\text { Waarvan honden vaker bijten dan } \\
\text { op grond van hun aantal wordt } \\
\text { verwacht }\end{array}$} \\
\hline Rottweiler & 40 & 3,9 & $<0,001$ \\
\hline Dobermann & 12 & 3,2 & $<0,01$ \\
\hline Duitse herder & 75 & 2,9 & $<0,001$ \\
\hline Belgische herder & 58 & 2,1 & $<0,001$ \\
\hline Bouvier & 19 & 1,8 & $<0,05$ \\
\hline Jackrussellterriër & 114 & 1,5 & $<0,001$ \\
\hline \multicolumn{4}{|c|}{$\begin{array}{l}\text { Waarvan honden minder vaak } \\
\text { bijten dan op grond van hun aantal } \\
\text { wordt verwacht }\end{array}$} \\
\hline Golden retriever & 32 & 0,6 & $<0,01$ \\
\hline Labrador retriever & 32 & 0,5 & $<0,001$ \\
\hline Yorkshireterriër & 9 & 0,5 & $<0,05$ \\
\hline Maltezer & 15 & 0,4 & $<0,001$ \\
\hline Cavalier King Charles-spaniël & 5 & 0,3 & $<0,01$ \\
\hline
\end{tabular}

Een ras specifieke bijtindex (BRI) laat zich vaak slecht afleiden uit de aanwezige data (Overall, 2010). Het ras of type gebonden bijtrisico van honden kan alleen juist worden berekend als naast het aantal honden van een bepaald ras of type dat bijtincidenten veroorzaakt (de noemer), ook het totaal aantal aanwezige honden van het betreffende ras of type (de teller) bekend is. Deze methodiek is toegepast door Cornelissen en Hopster (2008). In tabel 4 staat het aldus berekende relatieve bijtrisico voor enkele bij (opzettelijke en niet opzettelijke) bijtincidenten betrokken rassen. Een BRI lager of hoger dan 1 duidt erop dat honden van dat ras respectievelijk minder vaak of vaker bijten dan op grond van hun aantal mag worden verwacht. Ondanks het feit dat er significante verschillen tussen rassen gevonden werden concludeerden de auteurs dat deze bevindingen het niet rechtvaardigen om rassen in zijn geheel te verbieden. Cruciaal werd geacht hoe de eigenaar met de hond omgaat en deze onschadelijk houdt. Overigens kwamen honden van het type Pitbull in dit publieksonderzoek niet voor omdat deze ten tijde van het onderzoek verboden waren en dus illegaal. Eigenaren waren daardoor naar verwachting niet bereid om dit type te vermelden of hier mededelingen over te doen.

Ook Duffy et al (2008) onderzochten mogelijke verschillen in agressie (naar vreemden, de eigenaar of andere honden) tussen rassen met behulp van een zogenaamde C-BARQ vragenlijst ingevuld door ruim 1500 eigenaren van honden (tussen de 1 en 17 jaar oud) die aangesloten waren bij 11 Amerikaanse zogenaamde kennelclubs (vergelijkbaar met de Raad van Beheer) en bijna 3800 online ingevulde vragenlijsten. 

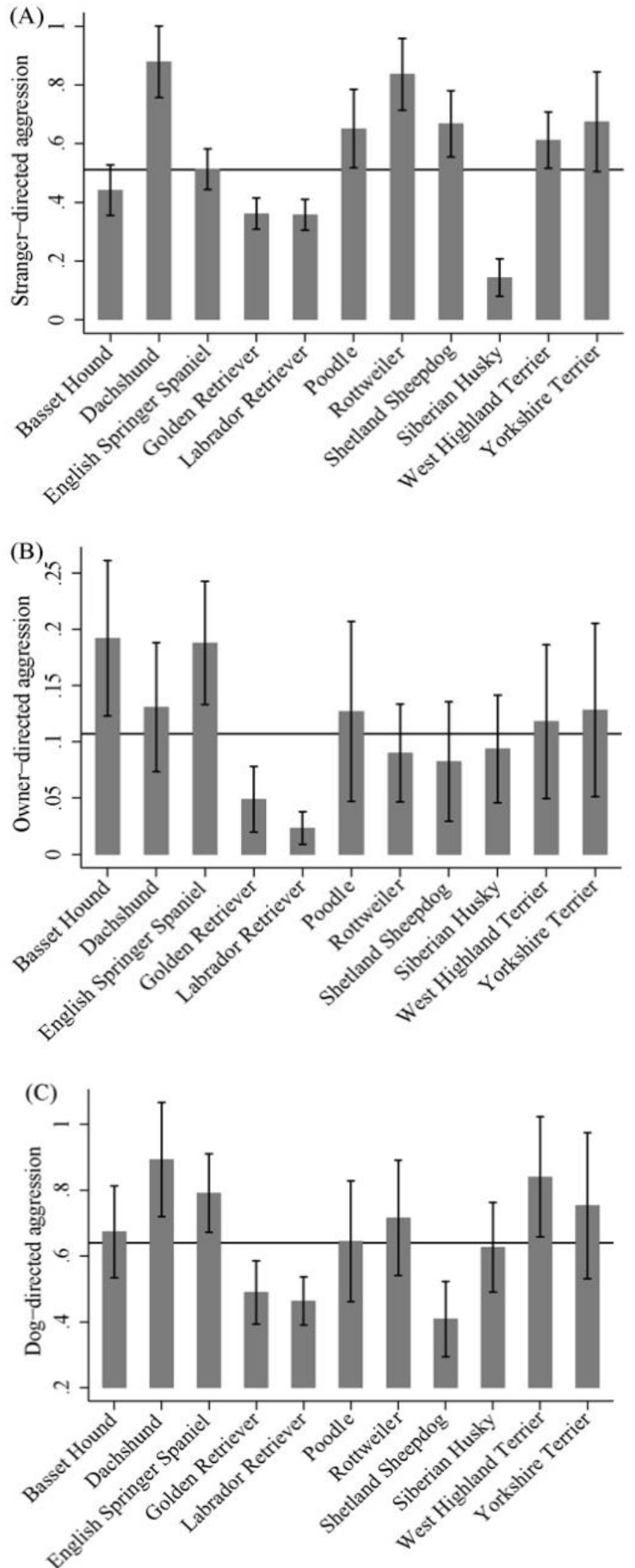

Figuur 3 Verschillende vormen van agressie en de score daarop van verschillende hondenrassen (Duffy et al., 2008)

Kynologisch Gebied in Nederland het initiatief 'Fairfok', waarmee de huidige stamboom zich op termijn ontwikkelt tot een soort keurmerk voor gezonde en sociale rashonden (Raad van Beheer, 2014). Onderdeel daarvan is een gedragstest. Het slagen voor de gedragstest voordat een hond ingezet mag worden voor de fokkerij is bij een aantal rassen al vanaf 2014 bestaand beleid.

\subsection{Eigenar/houder}

De relatie tussen hond en mens hangt af van de persoonlijkheidskenmerken van zowel mens als hond, hoe de mens zijn relatie met de hond ziet en de manier waarop de mens met de hond communiceert. 
Zie ook de paragraaf over socialisatie en training. Volgens Blouin (2013) zien mensen hun hond globaal vanuit één van de drie oriëntaties: 'gebruiker', 'relatie' of 'gelijke andere'. De 'gebruiker' heeft een relatief lage achting voor de hond en waardeert deze vooral vanwege zijn nut voor de mens, bijvoorbeeld bescherming. De op de relatie georiënteerde eigenaar ziet de hond als vervanger van de medemens en waardeert vooral diens affectieve waarde. De 'gelijke andere', meer biocentrisch georiënteerde eigenaar heeft een hoge achting voor de hond en respecteert deze als metgezel en als wezen met eigen belangen.

Duijnker (2016) geeft aan dat er verschillende motivaties van eigenaren zijn te onderscheiden om een hond te houden, waaronder het vergroten van hun eigen status of het bewaken van goederen of de houder zelf. Zij haalt Hallsworth (2011) aan die aangeeft dat honden die aangeschaft worden vanwege de status die ze opleveren, vaak slecht getraind, verwaarloosd en niet onder controle worden gehouden.

Turcsán et al. (2012) vonden dat mensen met persoonlijkheidskenmerken als neurotisch, extravert, zorgvuldig, open of voorzichtig vooral honden hadden die diezelfde karaktereigenschappen vertoonden. Schenk et al. (2012) vonden dat eigenaren van zogenaamde 'gevaarlijke' honden vaker agressief gedrag vertoonden en daar ook vaker voor waren veroordeeld dan eigenaren van honden die niet als gevaarlijk bekend staan. Wells en Hepper (2012) suggereren dat eigenaren van 'gevaarlijke' honden vaker antisociale neigingen vertoonden dan eigenaren van rassen die bekend staan als minder agressief. Mensen zijn blijkbaar geneigd om een hond uit te zoeken die qua persoonlijkheid op hen lijkt.

Deze associatie tussen hond en eigenaar kan onbewust het beeld dat honden van bepaald type gevaarlijk zijn versterken. Creedon \& Ó Súilleabháin (2017) toonden in dat verband aan dat het aanwijzen van hondenrassen en -typen als hoog-risico dieren ('legislated breeds') de risico perceptie van mensen beïnvloedt waardoor zij eerder besluiten tot melding van gevaarlijke situaties en tot aangifte van bijtincidenten bij de autoriteiten.

Om een goede band op te bouwen met een hond moet de eigenaar het gedrag en de lichaamshouding van de hond goed kunnen interpreteren waardoor de communicatie goed kan verlopen. Niet iedereen is daartoe even goed in staat (Mills, et al., 2014). Meyer en Forkman (2014) geven aan dat als mensen gevoelig zijn voor de non-verbale communicatie, dit een positief effect heeft op de mens-hond relatie. Meestal verbetert ervaring de non-verbale communicatie van mens naar hond en daarmee ook de interpretatie van het gedrag van de hond (Tami \& Gallagher, 2009; Meyer \& Forkman, 2014).

Angst, vriendelijk gedrag en uitnodigen tot spelen worden vaak goed herkend maar agressief gedrag, zelfverzekerdheid en speelgedrag worden minder goed herkend (Tami \& Gallagher 2009). Het is geen uitzondering dat eigenaren het gedrag van de hond verkeerd interpreteren. Zo kunnen eigenaren schrikken van hun eigen hond die 'de tanden laat zien' en dit interpreteren als agressief gedrag terwijl de hond als kalmeringssignaal zijn tanden laat zien (soort grinniken) (Zawistowski and Reid, 2016). Ook kan de band tussen mens en hond op de proef worden gesteld als de mens de hond affectie toont, zoals het knuffelen van de hond, en de hond hierop afwijzend reageert met gedrag dat door de mens als agressief wordt geïnterpreteerd zoals snauwen of grauwen (Mills et al., 2014).

Meyer en Forkman (2014b) concluderen dat de begeleider van een hond vaardigheden nodig heeft om bij de hond signalen van onveiligheid of ongemak te herkennen en dat het trainen van honden om om te gaan met mensen die deze sociale vaardigheden missen een positieve invloed heeft op de hond.

\subsection{Context}

Naast de hond en de eigenaar speelt de context waarin een bijtincident plaats vindt een belangrijke rol. Uit een nadere beschouwing van de context kan bijvoorbeeld duidelijk worden of de hond gebeten heeft in een spelsituatie (onbedoeld), of deze aangelijnd of los was, wel of niet onder appel stond, gericht gebeten heeft na het ervaren van een dreigende situatie (bijvoorbeeld bedreiging van familielid of eigendom door een vreemde), of als gevolg van pijn gebeten heeft (bijvoorbeeld bij behandeling bij de dierenarts) of vooraf aangegeven heeft dat hij zou gaan bijten maar dat deze waarschuwingssignalen door het slachtoffer werden genegeerd.

\subsubsection{Bijtincident hond-mens}

Oxley et al. (2017) deden navraag bij 484 slachtoffers van bijtincidenten en brachten onder meer in beeld dat bijtincidenten meestal $(66,1 \%)$ veroorzaakt werden door een voor het slachtoffer bekende hond, gewoonlijk in een context van aaien, spelen, hanteren of fixeren. Ook werd een beet van een eigen hond, meer dan die van een minder bekende hond, beschouwd als een ongelukje en als 
onbedoeld. In hun analyse van bijtincidenten met de mens als slachtoffer vonden Cornelissen en Hopster (2008) dat een derde deel (37\%) ervan plaats vond in de publieke ruimte. Volwassenen (42\%) waren daar vaker het slachtoffer van dan kinderen (24\%). Ook uit deze studie bleek dat de meeste bijtincidenten (61\%) zich voor deden in de huiselijke kring en dat daarbij de eigen of een bekende hond betrokken was. Kinderen waren daarbij vaker het slachtoffer dan volwassenen en lokten de incidenten dikwijls onbewust uit omdat zij normaal hondengedrag niet goed interpreteerden.

Bradley (2014) geeft aan dat een aantal bepalende factoren vaak samengaat bij een bijtincident. Dit zijn het niet aanwezig zijn van een persoon die op een juiste manier weet te interveniëren, het slachtoffer heeft geen band met de hond, de hond is niet geneutraliseerd, het slachtoffer is door leeftijd of fysieke conditie niet in staat om de hond op een voor deze niet bedreigende manier te benaderen, de eigenaar van de hond houdt de hond als erfhond en niet zozeer als huisdier, voorafgaand aan het bijtincident werd de hond al niet goed gemanaged en/of was er sprake van misbruik of verwaarlozing van de hond.

De Keuster \& Butcher (2008) betogen dat een bijtincident altijd een reflectie is van de aard van de mens-hond interactie, en dat inzicht in de culturele achtergrond ervan essentieel is voor het kunnen bedenken en implementeren van effectieve bijtpreventie strategieën.

Rosado et al. (1995) hebben de context van 169 bijtincidenten (van de in totaal 4.186 onderkende bijtincidenten) in hun publicatie opgenomen waaruit blijkt dat de oorzaken divers waren variërend van reactie op behandeling bij de dierenarts, tijdens het scheiden van vechtende honden of alleen langs de hond lopen, rennen of fietsen. Een derde van deze bijtincidenten gebeurde tijdens het helpen van een hond of het uit elkaar halen van vechtende honden. Hieruit zou geconcludeerd kunnen worden dat de mens zeker niet altijd een bewust doel is voor de bijtende hond. Ook uit de studie van Cornelissen en Hopster (2010) komt dat bijna een derde van de bijtincidenten als 'onbedoelde beet' kan worden beschouwd.

Het kind dat slachtoffer is van een bijtincident kan een bepaalde rol hebben gespeeld vlak voor en/of tijdens het incident waarbij het toezicht van de ouder tekort schiet (Ozanne-Smith et al., 2001; Arhant et al., 2016; Overall, 2010; Bradley, 2014; Basu et al., 2016). Ook Butcher (2006) geeft aan dat een ernstig bijtincident waarbij het kind een slachtoffer is, vaak geïnitieerd is door de interactie van het kind met de hond. Kinderen worden relatief vaak in het hoofd, de nek en het gezicht gebeten (Overall and Love, 2001; Butcher, 2006; Heinze et al., 2014; Basu, Ryba and Osher, 2016; Beata et al., 2017). Naarmate kinderen jonger zijn werden ze vaker in het hoofd en minder vaak in de onderste ledematen gebeten (Cornelissen en Hopster, 2008). Sacks et al. (1996) rapporteren een ruim drie keer zo hoge kans dat jonge slachtoffers medische hulp nodig hebben door een bijtincident.

\subsubsection{Bijtincident hond-hond of ander dier}

Informatie over het aantal bijtincidenten waarbij het slachtoffer niet een mens maar een hond of een ander dier is, is vrijwel niet beschikbaar in de literatuur. Agressie tussen onbekende honden in het Verenigd Koninkrijk komt volgens Casey et al. (2013), op basis van een door 3.897 hondeneigenaren ingevulde enquête, regelmatig voor. Een op de vijf (22\%) hondeneigenaren heeft dit één of meerdere keren meegemaakt. Acht procent van de eigenaren rapporteerde agressie tussen honden uit hetzelfde huishouden. Řezáč et al. (2011) observeerde in de Tsjechische Republiek de interactie tussen honden. $\mathrm{Zij}$ vonden dat in $15 \%$ van de interacties tussen honden sprake was van een dreiging. In $3 \%$ van de interacties werd er gebeten. Bijtincidenten vonden 4 keer zoveel plaats als de honden van gelijk geslacht waren. Van 60 strafzaken over bijtincidenten in het arrondissementparket Rotterdam (2000 t/m 2006) bleken er 37 zaken een hond-mens incident, 20 zaken een hond-hond incident en 3 een hond-ander dier incident te betreffen (Cornelissen en Hopster, 2008).

\subsubsection{Inzet van honden bij gevechten}

In 2016 heeft de politie in Amersfoort drie personen aangehouden op verdenking van betrokkenheid bij hondengevechten ${ }^{10}$. Op drie adressen werden vervolgens bij huiszoekingen 25 Pitbulls in beslag genomen, waaronder 11 pups. De honden ondergingen een gedragstest, maar een groot deel van de honden vormde door hun agressieve gedrag een blijvend gevaar voor de samenleving. Voor deze honden bleek euthanasie de enige optie. Dit voorval illustreert dat het niet is uit te sluiten dat hondengevechten ook in Nederland aan de orde zijn.

\footnotetext{
10 https://www.politie.nl/nieuws/2016/oktober/6/03-drie-aanhoudingen-in-onderzoek-naar-hondengevechten.html
} 
Het fenomeen dat honden, voornamelijk van het type Pitbull, worden getraind en ingezet voor hondengevechten is uitgebreid beschreven door Duijnker (2016). Het opvoeden en trainen van dit type honden voor deelname in hondengevechten, verstrekt de beeldvorming dat dit type honden van nature gevaarlijk gedrag vertoont. Met een verwijzing naar Hallsworth (2011) betoogt zij dat dit type honden vaak wordt aangeschaft vanwege de status die ze de eigenaar opleveren. Het beeld dat mensen hebben van dit type hond als zijnde agressief, onverschrokken en gevaarlijk is ook volgens Harding (2014) voor bepaalde eigenaren juist de reden om dit type honden aan te schaffen. Volgens Hallsworth (2011) ligt het echte probleem dan ook niet zozeer bij de hond, maar vooral bij de (vaak jonge, onverantwoordelijke) eigenaren die hun hond onvoldoende trainen en opvoeden, verwaarlozen en niet onder controle houden waardoor deze een gevaar voor de omgeving oplevert.

\subsection{Conclusies uit de literatuur}

Bijtincidenten ontstaan uit een samenspel tussen verschillende factoren die globaal zijn toe te wijzen aan eigenschappen van de hond, aan hoe de eigenaar/begeleider met de hond omgaat en aan de omstandigheden waarin de hond tot het bijten van het slachtoffer is overgegaan.

Hond: Iedere hond kan bijten, ongeacht ras, leeftijd of sekse. De neiging daartoe verschilt tussen rassen en typen maar daarbinnen ook tussen foklijnen en individuele dieren. De verschillen tussen rassen en typen voeren terug naar de functie waarvoor het ras oorspronkelijk is gefokt (en/of wordt gefokt) en het gedrag en het formaat dat hiervoor passend is. Gedrags- en uiterlijke kenmerken hangen daarom vaak samen. Problemen die geassocieerd worden met agressief gedrag komen derhalve voort uit de expliciete aandacht voor agressie in het fokdoel. Honden van rassen of foklijnen binnen rassen die zijn geselecteerd op agressie tegen vreemden (bescherming) of op prooiagressie (vechten, doden) kunnen problematisch gedrag vertonen indien er onvoldoende aandacht is besteed aan socialisatie, opvoeding, verzorging en training. De ernst van een bijtincident wordt onder meer bepaald door de kracht die een hond tijdens het bijten uitoefent op het slachtoffer. Daarbij bepaalt voornamelijk het formaat van de hond de bijtkracht die deze kan uitoefenen. Leeftijd speelt in die zin een rol, dat vooral in de kritische socialisatie periode de fokker, naast de nieuwe eigenaar van de pup, een grote invloed heeft op de wijze waarop de jonge hond leert reageren op prikkels in zijn omgeving. Reuen lijken vaker bijtincidenten te veroorzaken dan teven, voor wat betreft de invloed van castratie is de literatuur niet eenduidig.

Eigenaar: Socialisatie, opvoeding en training verklaren een groot deel van de variatie in problematisch gedrag binnen rassen en zijn sterk gerelateerd aan de persoonlijkheidskenmerken van de hondeneigenaar. Mensen hebben uiteenlopende motivaties om een hond te fokken (bijvoorbeeld inkomsten, liefhebberij) of te houden (bijvoorbeeld status, gezelschap, bescherming, hulp), onderhouden met honden relaties die verschillen in de mate waarin de hond tot hun gevoel spreekt, zijn meer of minder effectief in de communicatie met hun hond en tonen meer of minder verantwoordelijkheid waar het de omgang met de hond betreft. Mensen lijken geneigd om een hond aan te schaffen die qua persoonlijkheid op hen lijkt. Bij het risico op bijtincidenten kan de bijdrage van de hond niet los gezien worden van de bijdrage van diens eigenaar.

Een onbekend deel van de eigenaren van honden van het type Pitbull heeft criminele antecedenten en ontleend aan dit soort honden een imponerende status en/of zet deze honden in bij (honden)gevechten.

Context: Bijtincidenten doen zich vaak voor in de huiselijke kring en worden vaak veroorzaakt door een voor het slachtoffer bekende (eigen) hond, gewoonlijk in een context van aaien, spelen, hanteren of fixeren. In de huiselijke kring zijn kinderen vaker het slachtoffer dan volwassenen, onder andere als het toezicht van volwassenen (ouder) tekort schiet. Een beet van een bekende hond wordt, vaker dan die van een minder bekende hond, beschouwd als onbedoeld en als ongelukje. Het aantal meldingen van dit soort incidenten zal daarom relatief laag zijn. In de publieke ruimte zijn volwassenen vaker dan kinderen het slachtoffer. De aanleiding voor een bijtincident is daar divers, variërend van het scheiden van vechtende honden tot langs de hond lopen, rennen of fietsen. Over de context waarin honden het slachtoffer zijn van een bijtincident is in de literatuur vrijwel niets bekend.

Analyse bijtincidenten: De diverse studies over bijtincidenten laten zich niet altijd gemakkelijk vergelijken. In het algemeen geldt dat bijtincidenten, inclusief de toedracht, niet systematisch en volledig worden geregistreerd. De gehanteerde definities betreffende 'bijten' tussen studies verschillen 
en de factoren die hierbij een rol spelen worden niet eenduidig vastgelegd. Bovendien verschillen de juridische en maatschappelijke contexten tussen landen.

Desondanks ontstaat het beeld dat honden van bepaalde rastypen (o.a. type Pitbull, Rottweiler) vaker betrokken zijn bij (ernstige) incidenten, voor zover deze door de politie en/of door de media zijn geregistreerd. Dat dit type honden ernstiger letsel veroorzaakt, daarover zijn de resultaten uit onderzoek niet eenduidig. Beeldvorming speelt evenwel een grote rol. Het aanwijzen van honden van specifieke rassen of typen als gevaarlijke hond blijkt van invloed op de risicoperceptie van burgers waardoor zij eerder melding maken van gevaarlijke situaties en vaker aangifte doen van bijtincidenten waarbij honden van deze rassen of typen betrokken zijn.

Samenvattend wordt geconcludeerd dat diverse factoren de kans op (een ernstig) bijtincident vergroten. Dit zijn rassen en daarbinnen foklijnen waarbij aanvalskracht (gedrag, bouw, formaat) onderdeel is (geweest) van het fokdoel. Daarnaast speelt in de kritische socialisatie periode de fokker, naast de nieuwe eigenaar van de pup, een grote rol in het vertrouwd maken van de hond met prikkels in zijn (toekomstige) omgeving. Socialisatie, opvoeding en training verklaren mede de variatie in problematisch gedrag binnen rassen en zijn, net als het vermogen van de eigenaar om het gedrag van de hond goed te kunnen begrijpen, geassocieerd met de persoonlijkheidskenmerken van de hondeneigenaar. Tenslotte is het vooral diegene onder wiens toezicht de hond zich bevindt (eigenaar, begeleider, volwassene), die verantwoordelijk is voor de omstandigheden waarin de hond wordt uitgelokt of de gelegenheid wordt geboden om te bijten.

Al zou er al een betrouwbare inschatting mogelijk zijn voor verschillen in bijtrisico's tussen hondenrassen of typen, dan nog resteren er veel andere factoren die bepalen of en met welke gevolgen een hond zal bijten en een gevaar voor zijn omgeving zal zijn. Dat betekent dat het terugdringen van bijtincidenten en het verbeteren van het gevoel van veiligheid bij burgers vraagt om de inzet van meer beleidsinstrumenten dan alleen die gericht zijn op het beperken van de invloed van bepaalde hondenrassen.

"Problems of irresponsible ownership are not unique to any breed, nor will they be in the future. Effective animal control legislation must emphasize responsible and humane ownership of genetically sound animals, as well as the responsible supervision of children and animals when they interact" (Lockwood, 2016). 


\section{$5 \quad$ Actuele cijfers uit Nederland}

In Nederland wordt niet éénduidig, volledig en structureel bijgehouden hoeveel mensen en (huis)dieren het slachtoffer zijn van een bijtincident. Wel kan uit verschillende registratiesystemen een beeld gevormd worden van het aantal bijtincidenten. De volgende bronnen zijn hiervoor beschikbaar:

1. Melding bij de politie van een bijtincident;

2. Behandeling van letsel bij een persoon na een bijtincident
a. bij de huisarts
b. bij de spoedeisende eerste hulp
c. opname in ziekenhuis

3. Het aantal mensen dat overlijdt door een beet van een hond gerapporteerd in de doodsoorzakenstatistiek van het CBS;

4. In beslaggenomen honden na een bijtincident

In bijlage 1 staat een toelichting op de cijfers uit de beschikbare registratiesystemen.

In dit hoofdstuk staat het aantal meldingen van een bijtincident, het aantal voor een bijtwond behandelde mensen en dieren, het aantal als gevolg van een hondenbeet overleden mensen en het aantal in beslag genomen honden zoals deze uit de registratiesystemen te halen viel weergegeven.

\subsection{Meldingen bij de politie}

Het aantal meldingen van een 'gevaarlijke hond' in Nederland, zoals opgenomen in BlueSpot monitor onder code E82 door de politie, ligt rond de 3.000 per jaar (tabel 5). Deze meldingen kunnen betrekking hebben op een dreiging of op een daadwerkelijk bijtincident hond-mens of hond- ander dier. Zie voor verdere toelichting op deze registraties bijlage 1.

Tabel 5 Politieregistraties in BlueSpot Monitor onder 'gevaarlijke hond' in Nederland in 2010 tot en met 2014 (Leiden et al., 2016) en 2015 tot en met juni 2017 (via de hondengeleiders Amsterdam)

\begin{tabular}{|lcccccccc|}
\hline Jaar & 2010 & 2011 & 2012 & 2013 & 2014 & 2015 & 2016 & $\begin{array}{l}2017 \\
\text { juni }\end{array}$ \\
\hline $\begin{array}{l}\text { Aantal } \\
\text { registraties }\end{array}$ & 1.779 & 2.893 & 3.047 & 3.277 & 3.588 & 3.250 & 3.596 & 1.783 \\
$\begin{array}{l}\text { 'gevaarlijke } \\
\text { hond' }\end{array}$ & & & & & & & & \\
\hline
\end{tabular}

\subsection{Behandeling door de huisarts}

De incidentieschatting voor een huisartsbezoek vanwege een beet (van mens/dier) over 2016 is de meest recente schatting van NIVEL Zorgregistraties eerste lijn: 4,6 per 1000 patiëntjaren. Dit komt overeen met 460 huisartsbezoeken per 100.000 inwoners oftewel 76.400 patiënten in Nederland. Opvallend hierbij is dat de incidentie bij mannen geschat wordt op 3,8 terwijl dit bij vrouwen met 5,4 hoger ligt. Dit verschil tussen mannen en vrouwen is consistent, ook in rapport 'Hondenbeten in perspectief' (Cornelissen en Hopster, 2008) lag het percentage tussen 2001 en 2006 hoger bij vrouwen dan bij mannen. In figuur 4 staan de incidentieschattingen van een bezoek aan de huisarts na een beet mens/dier over de jaren 2010 tot en met 2016.

In figuur 5 staat de verdeling van de incidentieschattingen van een bezoek aan de huisarts in 2015 in Nederland over de leeftijdscategorieën. Relatief gezien meldden zich meer kinderen bij de huisarts dan volwassenen. 


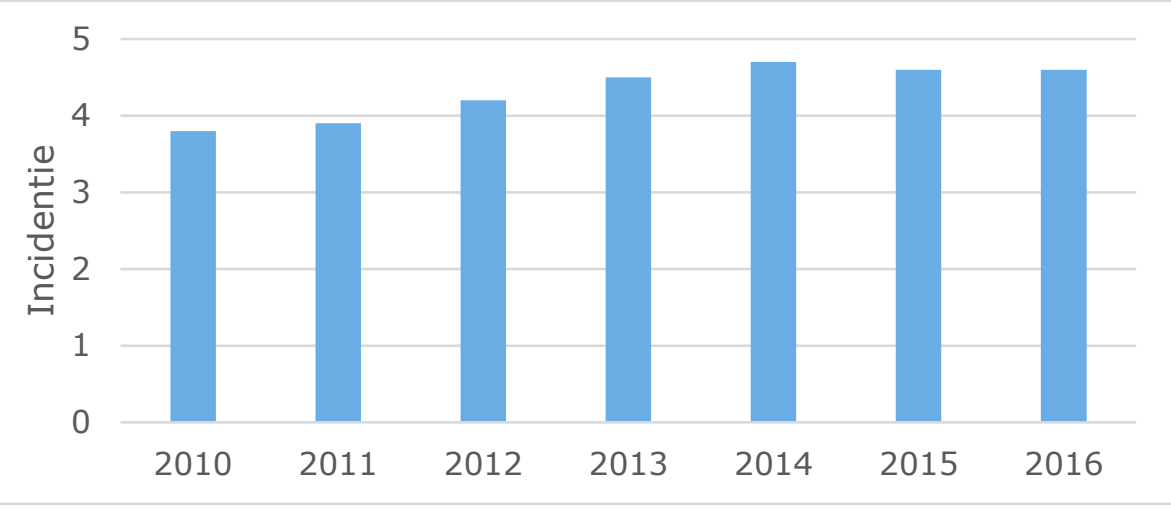

Figuur 4 Incidentieschatting in Nederland (aantal per 1.000 persoonsjaren) van een bezoek aan de huisarts na een hondenbeet in 2010 tot en met 2016 (bron: NIVEL Zorgregistraties eerste lijn)

In figuur 5 staat de verdeling van de incidentieschattingen van een bezoek aan de huisarts in 2015 in Nederland over de leeftijdscategorieën. Relatief gezien meldden zich meer kinderen bij de huisarts dan volwassenen.

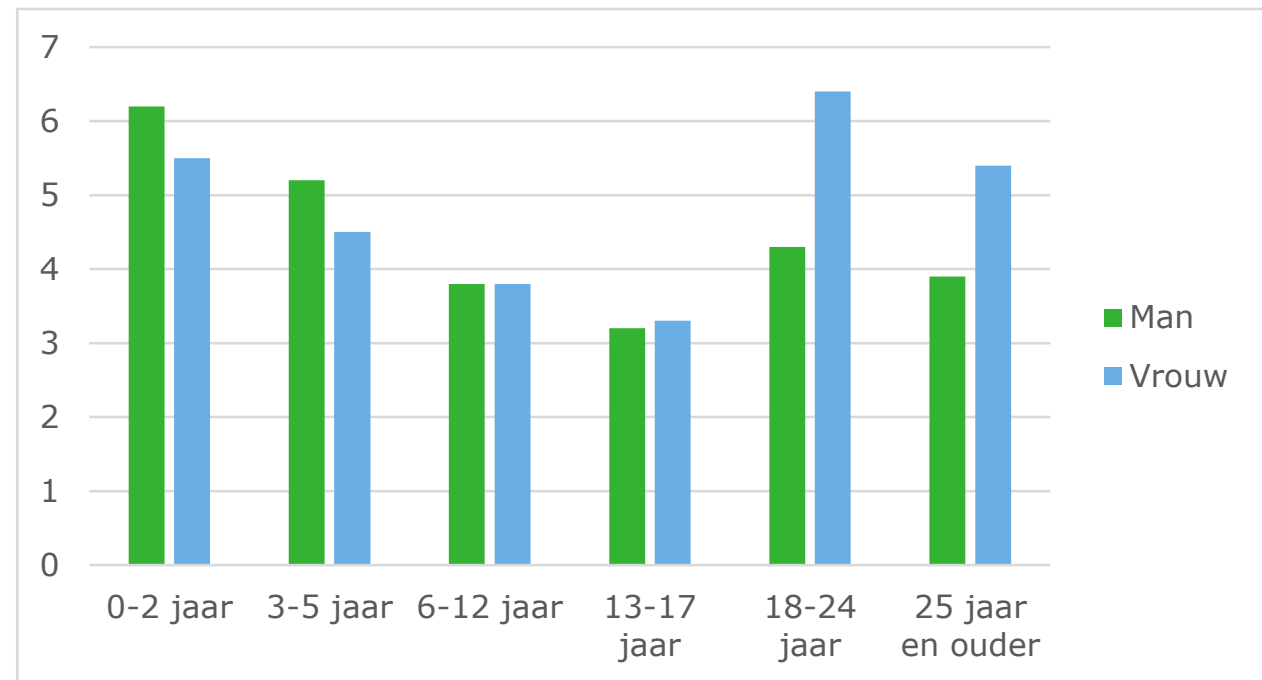

Figuur 5 Incidentieschatting (aantal per 1.000 persoonsjaren) van een bezoek aan de huisarts na een beet mens/dier in Nederland in 2015 voor mannen en vrouwen per leeftijdscategorie (bron: NIVEL Zorgregistraties eerste lijn)

\subsection{Behandeling bij de spoedeisende hulp}

In Nederland vonden in 20152.600 spoedeisende hulp (SEH) bezoeken plaats ten gevolge van letsel door een bijtincident wat neerkomt op 15,4 bijtincidenten per 100.000 inwoners waarvoor een bezoek aan de SEH werd gebracht (zie figuur 6, VeiligheidNL, 2017). 


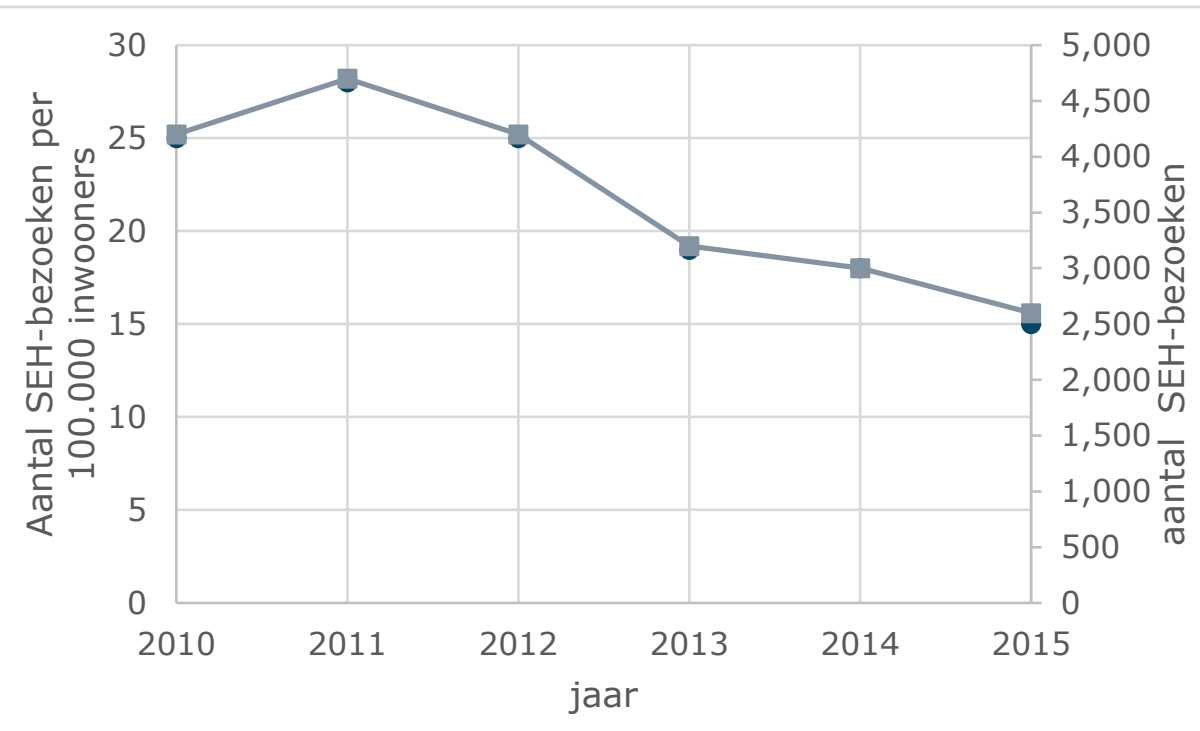

Figuur 6 Aantal SEH-bezoeken en aantal SEH-bezoeken per 100.000 inwoners na bijtincidenten in Nederland 2010-2015 (VeiligheidNL, 2017)

In de rapportage 'Hondenbeten in perspectief' staat een gemiddeld aantal SEH-bezoeken na een bijtincident van 3.200 over de jaren 1987 tot en met 1991 (Commissie van Wijzen, 2008). Het aantal bezoeken aan de SEH na een bijtincident lijkt na 2011 af te nemen.

\subsubsection{Locatie}

In 2015 werden de meeste letsels door bijtincidenten die werden behandeld bij de SEH opgelopen in het woonhuis $(400,16 \%)$, en met name genoemd de woonkamer (7\%) (zie tabel 6, VeiligheidNL, 2017). In de jaren 2010-2014 was dit ook het geval. Naast in het woonhuis kwamen bijtincidenten ook vaak voor op de straat of rijweg en in natuurgebieden. Hierbij dient wel te worden opgemerkt dat bij het merendeel (in 2015 zelfs 62\%) van de SEH bezoeken de locatie van het bijtincident onbekend is.

Tabel 6 Bijtincidenten in Nederland 2010-2015 op basis van SEH-bezoeken, naar locatie ongeval en jaar (Bron: Letsel Informatie Systeem 2010-2015, VeiligheidNL, * Lege cel = aantal te klein voor betrouwbare schatting)

\begin{tabular}{|c|c|c|c|c|c|c|c|c|c|c|c|c|}
\hline \multirow[b]{2}{*}{ LOCATIE } & \multicolumn{2}{|c|}{2010} & \multicolumn{2}{|c|}{2011} & \multicolumn{2}{|c|}{2012} & \multicolumn{2}{|c|}{2013} & \multicolumn{2}{|c|}{2014} & \multicolumn{2}{|c|}{2015} \\
\hline & $\begin{array}{l}\text { Aan } \\
\text { tal }\end{array}$ & $\%$ & $\begin{array}{l}\text { Aan } \\
\text { tal }\end{array}$ & $\%$ & $\begin{array}{l}\text { Aan } \\
\text { tal }\end{array}$ & $\%$ & $\begin{array}{l}\text { Aan } \\
\text { tal }\end{array}$ & $\%$ & $\begin{array}{l}\text { Aan } \\
\text { tal }\end{array}$ & $\%$ & $\begin{array}{l}\text { Aan } \\
\text { tal }\end{array}$ & $\%$ \\
\hline In woonhuis & 700 & 18 & 1.100 & 24 & 800 & 20 & 600 & 20 & 600 & 21 & 400 & 16 \\
\hline Om woonhuis & 300 & 6 & 400 & 8 & 300 & 8 & 300 & 10 & 200 & 8 & 100 & 6 \\
\hline Straat, rijweg & 600 & 15 & 700 & 14 & 800 & 18 & 400 & 14 & 400 & 12 & 200 & 8 \\
\hline $\begin{array}{l}\text { Handel, } \\
\text { dienstverlening }\end{array}$ & 100 & 3 & & & & & & & 100 & 3 & & \\
\hline Natuurgebied & 200 & 5 & 300 & 6 & 300 & 7 & 300 & 9 & 200 & 8 & 200 & 8 \\
\hline $\begin{array}{l}\text { Overig/ } \\
\text { onbekend }\end{array}$ & 2.200 & 53 & 2.200 & 48 & 2.000 & 47 & 1.500 & 48 & 1.400 & 48 & 1.600 & 62 \\
\hline Totaal & 4.100 & 100 & 4.700 & 100 & 4.200 & 100 & 3.200 & 100 & 3.000 & 100 & 2.600 & 100 \\
\hline
\end{tabular}

\subsubsection{Leeftijd en geslacht slachtoffer}

In tegenstelling tot bij huisartsbezoeken na een bijtincident, liepen iets meer vrouwen (52\%) dan mannen (48\%) letsel op vanwege een bijtincident waarvoor behandeling bij de SEH werd gezocht.

Uit de 2.600 SEH-bezoeken in 2015 ten gevolge van letsel door een bijtincident, gecorrigeerd voor bevolkingssamenstelling, blijkt dat kinderen tussen 0-5 jaar en 6-12 jaar het meeste risico op letsel liepen: $18 \mathrm{SEH}$-bezoeken per 100.000 inwoners van de betreffende leeftijdsgroep (zie figuur 7 en in bijlage 1: tabel 15). 


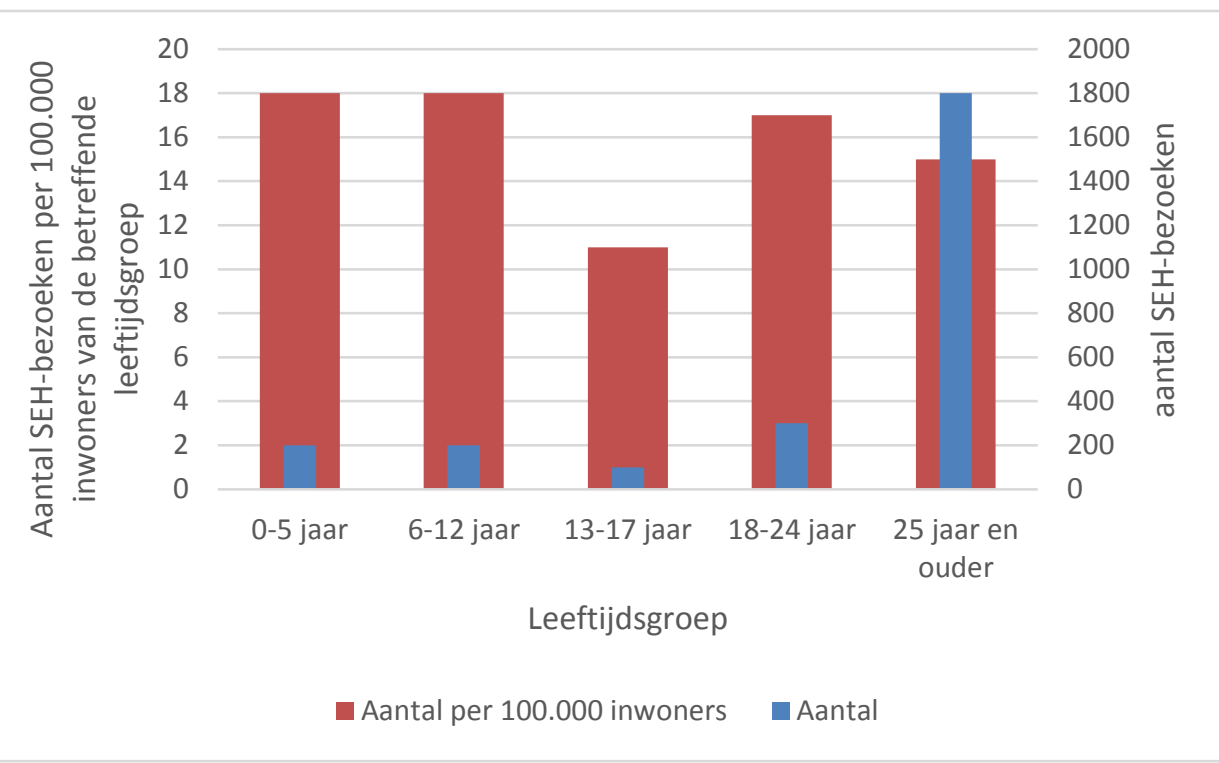

Figuur 7 Bijtincidenten in Nederland in 2015 op basis van SEH-bezoeken, naar leeftijd (Bron: Letsel Informatie Systeem 2010-2015, VeiligheidNL; Bevolkingsstatistiek 2010-2015, Centraal Bureau voor de Statistiek)

\subsection{Opname in een ziekenhuis}

In 2015 zijn 100 mensen, na een bezoek aan de spoedeisende hulp als gevolg van een hondenbeet, opgenomen in het ziekenhuis. Dit komt overeen met $\mathbf{0 , 8}$ ziekenhuisopnames per 100.0000 inwoners (zie tabel 7).

Tabel 7 Het aantal ziekenhuisopnamen na bezoek spoedeisende hulp na een bijtincident (Bron: Letsel Informatie Systeem 2010-2015, VeiligheidNL; Bevolkingsstatistiek 2010-2015, Centraal Bureau voor de Statistiek)

\begin{tabular}{|lcccccc|}
\hline Ziekenhuisopnames & 2010 & 2011 & 2012 & 2013 & 2014 & 2015 \\
\hline Aantal & 200 & 200 & 100 & 200 & 200 & 100 \\
\hline $\begin{array}{l}\text { Aantal per 100.000 } \\
\text { inwoners }\end{array}$ & 1 & 1,4 & 0,8 & 0,9 & 1,2 & 0,8 \\
\hline
\end{tabular}

\subsubsection{Letselschade}

In 2015 leidden SEH-bezoeken en ziekenhuisopnamen na SEH-bezoeken ten gevolge van hondenbeten in totaal tot $€ 791.000$ directe medische kosten (VeiligheidNL, 2017; tabel 8). Kosten van de bijtincidenten zijn met behulp van het zogenoemde Letsellastmodel berekend. Omdat de kosten tussen 2010-2015 fluctueren, is het te vroeg om te concluderen dat er sprake is van een daling van de totale directe medische kosten. Mogelijk dat er sprake is van een verschuiving van minder ernstige letsels naar huisartsenposten of huisartsen praktijken. Ook in de gemiddelde directe medische kosten per SEH-bezoek valt geen dalende lijn te ontdekken.

Tabel 8 Directe medische kosten na een bijtincident (gemiddeld en totaal) in 2010 tot en met 2015 (Bron: Letsel Informatie Systeem 2010-2015, VeiligheidNL; Letsellast Model 2010-2015, VeiligheidNL)

\begin{tabular}{|c|c|c|c|c|c|c|}
\hline $\begin{array}{l}\text { Medische kosten } \\
\text { (C) }\end{array}$ & 2010 & 2011 & 2012 & 2013 & 2014 & 2015 \\
\hline $\begin{array}{l}\text { Gemiddeld per } \\
\text { bijtincident }\end{array}$ & $4.226,-$ & $3.899,-$ & $4.235,-$ & $3.697,-$ & $3.374,-$ & $3.692,-$ \\
\hline Totaal & $1.304 .425,-$ & 1.162.628,- & $887.503,-$ & $860.501,-$ & $1.180 .154,-$ & 791.396,- \\
\hline
\end{tabular}




\subsection{Aantal mensen overleden aan een hondenbeet}

Een hondenbeet met dodelijk afloop komt relatief weinig voor, per jaar betreft het nul, één of hooguit twee personen. In de periode van 1996 tot en met 2016 zijn 21 personen overleden als gevolg van een aanval of een beet van een hond (cijfer over 2016 is voorlopig, statline.cbs.nl, doodsoorzakenstatistiek).

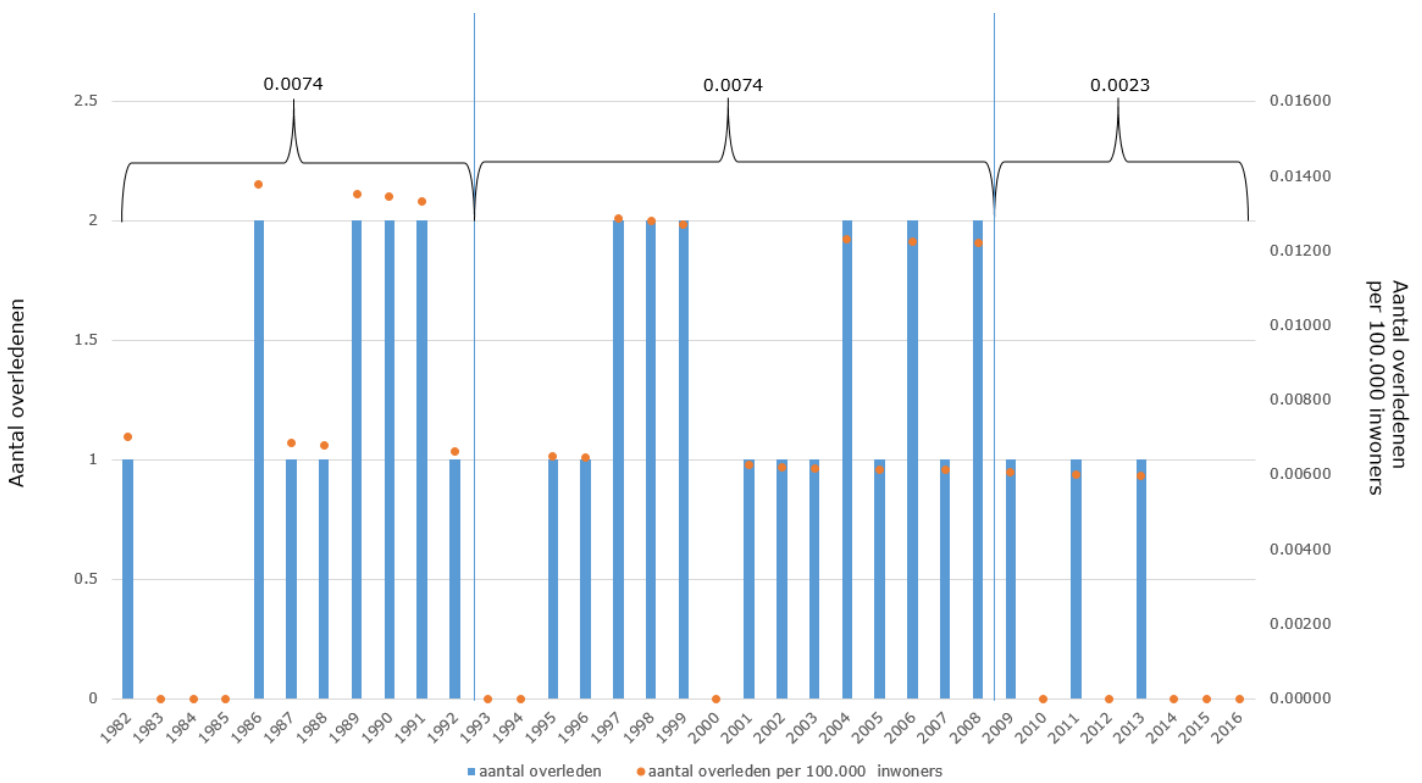

Figuur 8 Aantal in Nederland overleden personen per jaar (blauwe balkjes) en aantal overleden personen per 100.000 inwoners per jaar (oranje stip) als gevolg van een aanval/beet door een hond van 1982 tot en met 1995 (code E906) en van 1996 tot en met 2016 (code W54) (Bron: CBS,

http://statline.cbs.nI) Boven de accolades staan per 100.000 inwoners het gemiddelde aantal overleden personen in de periode voorafgaand aan de Regeling Agressieve Dieren (RAD), tijdens de RAD en na intrekking van de $R A D$

In de periode 1982 tot en met 1992 overleden 0,0074 mensen per 100.000 inwoners in Nederland per jaar, in de periode waarin de Regeling Agressieve Dieren (RAD) van toepassing was (1993 - 2008) was dit hetzelfde aantal (zie figuur 8). Nadat de RAD in 2009 is ingetrokken is het aantal gedaald tot gemiddeld $\mathbf{0 , 0 0 2 3}$ overledenen per 100.000 inwoners in de acht jaar daarna.

Onder de in totaal 21 slachtoffers waren 2 baby's (in 1997 en 2006) en 2 kinderen van onder de 10 jaar oud (1998 en 2003) (zie figuur 9).

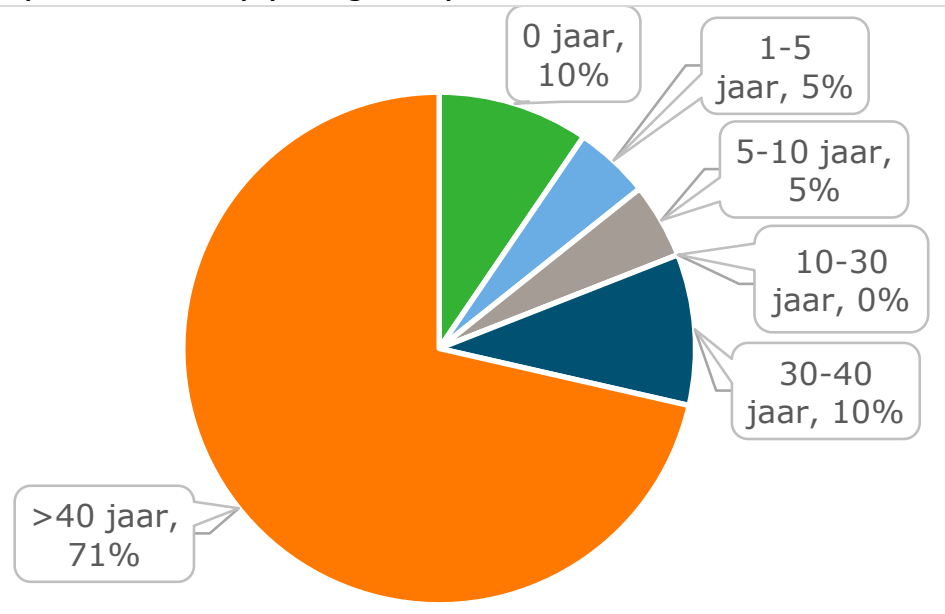

Figuur 9 Leeftijdsverdeling van de in totaal 21 overleden personen van 1996 tot en met 2016 (Bron: CBS, statline.cbs. nl, code W54) 


\subsection{Ras(type) hond die heeft gebeten}

In het Letselinformatiesysteem is het ras(type) van de hond die het bijtincident heeft veroorzaakt vrijwel nooit benoemd. In de gegevens van de 285 in 2015 geregistreerde incidenten ${ }^{11}$ is slechts in $14 \%$ van de gevallen een beschrijving van het ras(type) te vinden (zie tabel 9). Hierbij is het de vraag of de beschrijving niet meer is dan een inschatting door het slachtoffer op basis van het uiterlijk of op basis van de informatie gegeven door de eigenaar. Een en ander hoeft niet te kloppen met de werkelijke genetische achtergrond van de honden. Hieruit valt dan ook geen goed beeld te vormen van het ras(type) van de veroorzaker van het bijtincident. De bijtincidenten veroorzaakt door (15) politiehonden zijn waarschijnlijk het gevolg van de inzet van deze honden tijdens arrestaties, ordeverstoringen of ondersteuning van ME-optredens.

Tabel 9 Registratie van het ras(type) van de hond die het bijtincident veroorzaakte in de 10\% steekproef van de spoedeisende hulp en ziekenhuisopnames (Bron: Letsel Informatie Systeem 20102015, VeiligheidNL; Bevolkingsstatistiek 2010-2015, Centraal Bureau voor de Statistiek)

\begin{tabular}{|l|c|c|c|c|}
\hline Ras(type) & Aantal & \multicolumn{1}{|c|}{ Ras(type) } & Aantal & \multicolumn{2}{|c|}{ Ras(type) } \\
\hline Herdershond & 14 & Labrador & 2 & Waakhond \\
\hline Pitbull & 8 & Schnauzer & 1 & Politiehond \\
\hline Rottweiler & 6 & Teckel & 1 & Zwerfhond \\
\hline Stafford & 2 & Husky & 1 & Vuilnisbakkenras \\
\hline Boxer & 2 & Buldog & 1 & Onbekend \\
\hline $\begin{array}{l}\text { Jackrussell- } \\
\text { terriër }\end{array}$ & 2 & $\begin{array}{c}\text { Yorkshire- } \\
\text { terriër }\end{array}$ & 1 & TOTAL \\
\hline
\end{tabular}

\subsection{In beslag genomen honden}

De Rijksdienst voor ondernemend Nederland (RVO.nl) heeft gedurende de jaren 2013 tot en met 2016 in totaal 349 in beslag genomen honden geregistreerd. Gemiddeld 5 honden per 3 weken. Het betreft honden, betrokken bij bijtincidenten, die in bewaring zijn geweest bij RVO.nl. Ons is niet bekend wat er met de honden is gebeurd (getest, terug geplaatst, herplaatst, training, euthanasie, ..). In tabel 10 staan de in beslag genomen honden met daarbij, voor zover aangegeven, het ras(type). Meer dan de helft $(56,7 \%)$ van het aantal in beslag genomen honden behoort tot het type Pitbull, inclusief kruisingen daarmee. Het is niet bekend in hoeverre dit bij een stamboek aangesloten rashonden zijn. Bij een aantal honden (5\%) ontbreekt de typering van ras, type of kruising. Opvallend is dat in de lijst van in beslag genomen honden het ras/type Herder (Mechelse, Duitse, Hollandse, Anatolische, kruisingen) met 51 honden $(14,6 \%)$ is vertegenwoordigd. Relevant in dit verband is uiteraard dat het niet bekend is hoeveel honden van de verschillende ras(types) er voorkomen in Nederland waardoor hiermee weinig gezegd kan worden over het rasgebonden risico op een bijtincident.

\footnotetext{
${ }^{11}$ Dit is de steekproef van $10 \%$ waarop met behulp van de quotiënt-schatter de aantallen voor geheel Nederland zijn berekend
} 
Tabel 10 Registratie van het ras(type) van de in totaal 349 in beslag genomen honden in de periode 2013 tot en met 2016 (RVO.nl 2017)

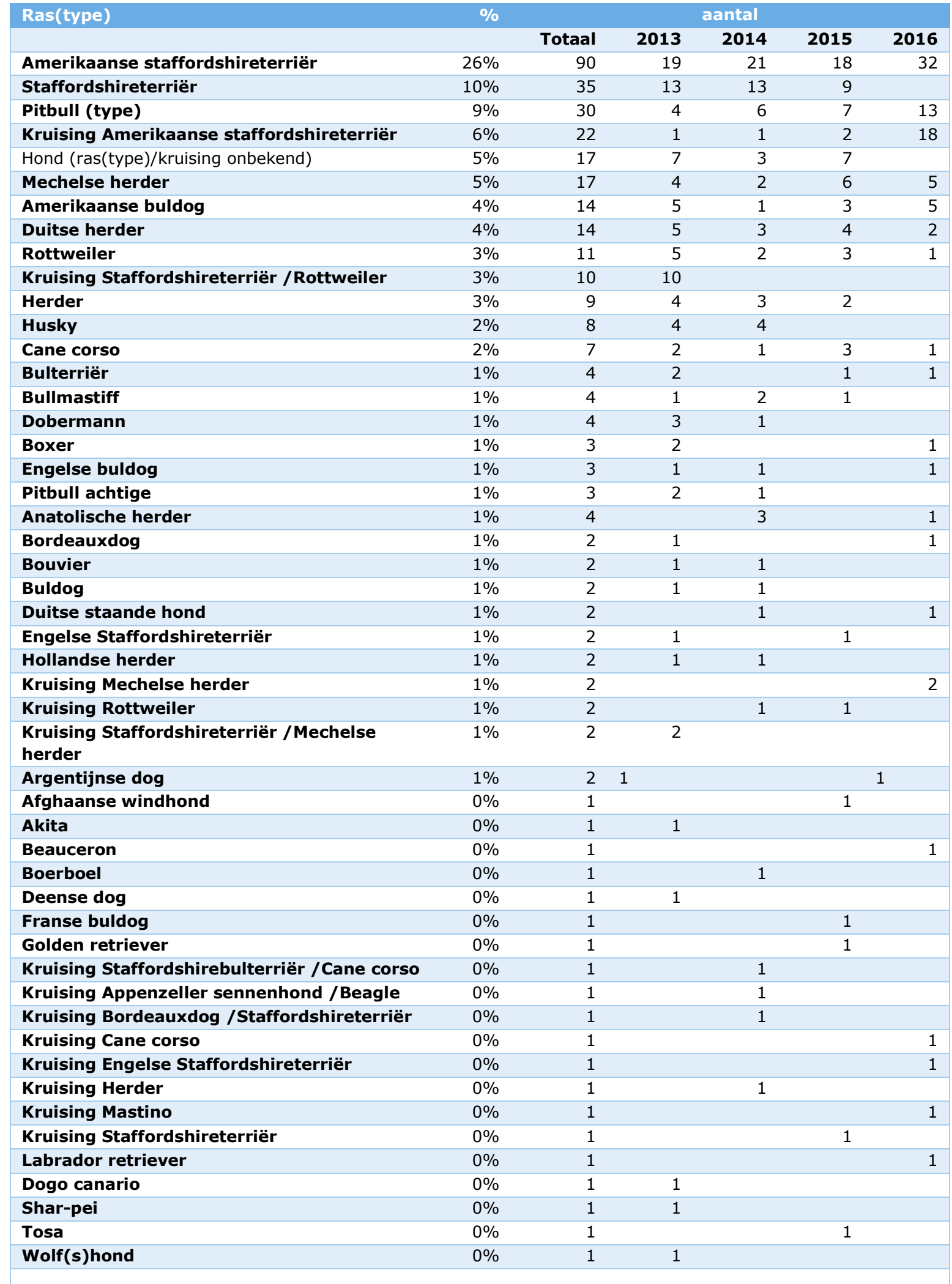




\section{Actuele cijfers uit Amsterdam}

\subsection{Meldingen bij de politie}

Waar in de BlueSpot Monitor van de politie landelijk jaarlijks rond de 3.000 meldingen van 'gevaarlijke hond' (code E82) te zien zijn, ligt dit aantal in de gemeente Amsterdam rond de 200 (zie tabel 11).

Tabel 11 Politieregistraties in BlueSpot Monitor onder 'gevaarlijke hond' in de gemeente Amsterdam (verkregen via de hondengeleiders van de politie Amsterdam) en het aantal door de politie geregistreerde bijtincidenten

\begin{tabular}{|l|l|l|l|l|l|l|}
\hline Jaar & 2012 & 2013 & 2014 & 2015 & 2016 & 2017 \\
\hline $\begin{array}{l}\text { Aantal registraties } \\
\text { 'gevaarlijke hond' }\end{array}$ & $117^{x}$ & 188 & 207 & 178 & 244 & $88^{y}$ \\
\hline \begin{tabular}{c} 
Aantal bijtincidenten \\
\hline
\end{tabular} & & & & 147 & 189 & $105^{z}$ \\
\hline
\end{tabular}

${ }^{x}$ vanaf 1 juni; ${ }^{y}$ tot 20 juni; ${ }^{z}$ tot en met 14 oktober

In de periode 2015 tot en met 2017 (t/m 14 oktober) zijn bij de politie Amsterdam in totaal 441 bijtincidenten geregistreerd. Dit is inclusief een onbekend, maar naar schatting gering aantal, incidenten waarbij niet is gebeten maar de situatie wel als bedreigend werd ervaren. Dit blijkt uit omschrijvingen als 'melder is meer geschrokken dan dat de hond daadwerkelijk heeft gebeten', 'hond snuffelde aan been slachtoffer waarna slachtoffer de hond heeft geschopt', 'er is niet gebeten en hond werd aangelijnd', 'net mis gebeten' of 'hond viel uit tegen kind maar niet gebeten'. Gemiddeld zijn er 158 bijtincidenten per jaar geregistreerd, ongeveer 3 per week. Van 18 bijtincidenten $(4,1 \%)$ is in die totale periode eveneens aangifte gedaan.

De politie geeft aan dat bij bijtincidenten betrokken personen een bijtincident niet altijd melden, laat staan aangifte doen, maar dit in bepaalde gevallen onderling regelen. Ook kunnen er bijtincidenten onder een ander BVH-nummer (Basisvoorziening Handhaving) zijn geregistreerd. Aangifte wordt bovendien niet altijd voorafgegaan door een melding, maar kan ook direct worden opgenomen en staat niet altijd in relatie tot de ernst van het bijtincident. Ook is niet uitgesloten dat aangiftes door de politie niet altijd zijn opgenomen, maar dat mensen die aangifte wilden doen onverrichter zake huiswaarts keerden. Tegen deze achtergrond zijn de registraties in tabel 11 niet meer dan illustratief.

Voor dit onderzoek heeft de politie Amsterdam (hondenbrigade) van genoemde 441 bijtincidenten over de periode 2015, 2016 en 2017 (t/m 14 oktober) gedetailleerde, geanonimiseerde gegevens aangeleverd volgens het format van de onderzoekers. Daarbij zijn de meldingen waarbij geen sprake was van een door een hond bedreigde situatie verwijderd. In de volgende paragrafen worden deze bijtincidenten nader geanalyseerd.

\subsubsection{Locatie}

De locatie van het bijtincident is ingedeeld naar openbare ruimte en privé terrein (zie figuur 10). Onder 'openbare voorzieningen' vallen locaties als horecagelegenheden, winkels, speeltuinen, stations en bus- of tramhaltes. De meeste bij de politie geregistreerde bijtincidenten vonden plaats op de openbare weg, inclusief fiets- en voetpaden (74\%) en in mindere mate op locaties met openbaar groen (15\%). Minder dan 1 op de 10 (9\%) geregistreerde bijtincidenten vond plaats op of nabij het privé terrein. 


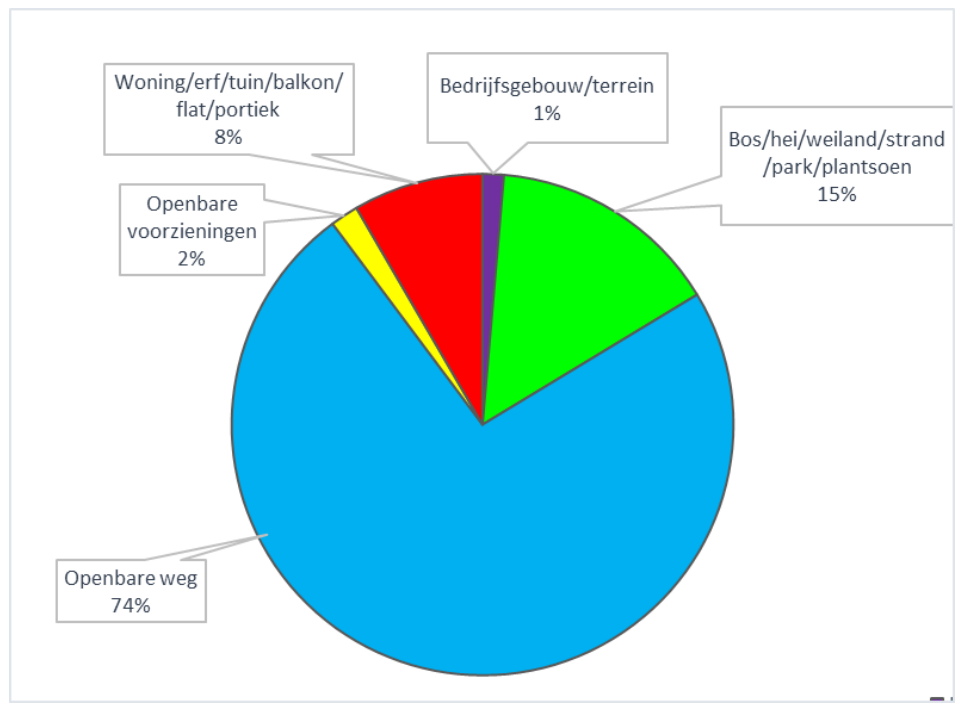

Figuur 10 Locatie van bij de politie geregistreerde bijtincidenten in Amsterdam in de periode 2015 2017 ( $t / m 14$ oktober 2017) $n=441$

\subsubsection{Seizoensinvloed}

Het aantal meldingen lijkt in de zomermaanden iets hoger te liggen dan in de rest van het jaar (zie figuur 11). Hetzelfde geldt voor het aantal bijtincidenten. De variatie binnen maanden tussen jaren is echter relatief groot, waardoor dit beeld van jaar op jaar kan verschillen.

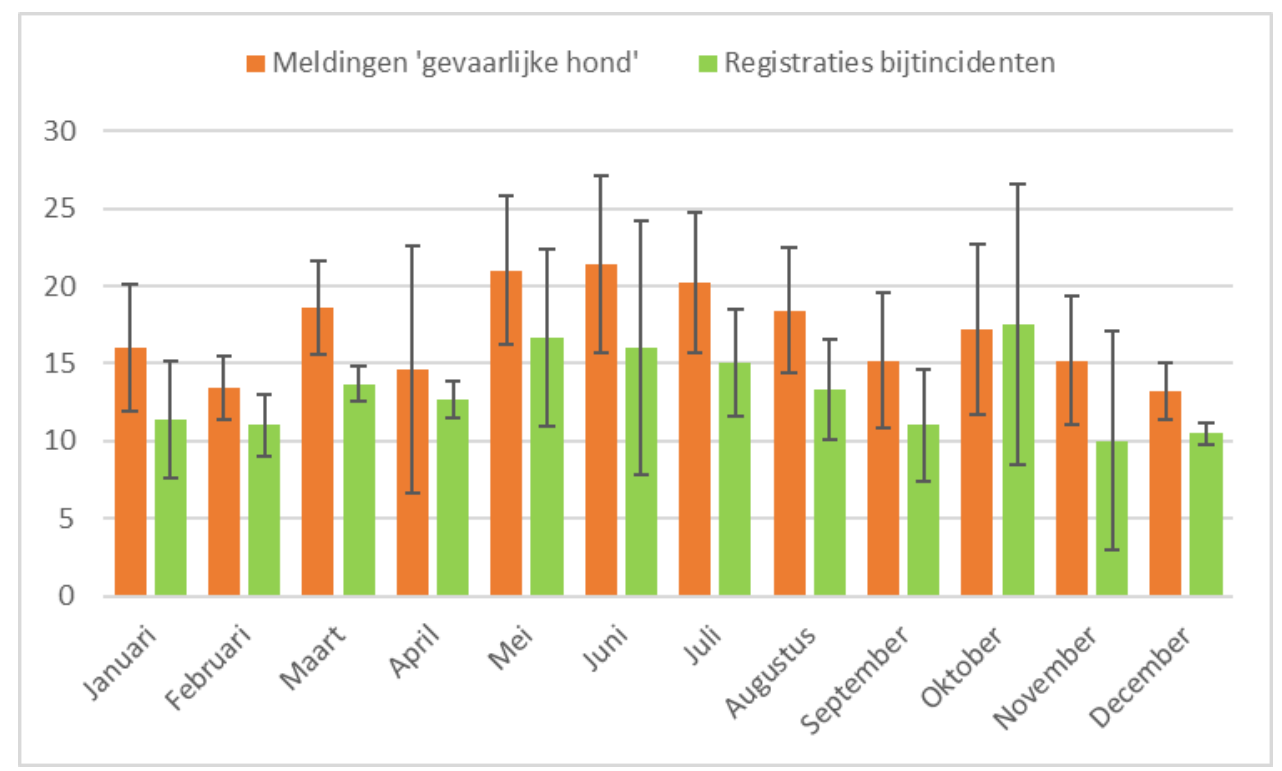

Figuur 11 Meldingen bij de politie van 'gevaarlijke hond' (juni 2012 t/m mei 2017) en registraties van bijtincidenten (januari 2015 t/m september 2017) in de gemeente Amsterdam, gemiddeld over de maanden van het jaar

\subsection{Behandeling door de huisarts}

In Amsterdam is de incidentieschatting van een huisartsbezoek na een beet mens/dier in 2015 (op basis van 22 huisartspraktijken ${ }^{12}$ ) 3,0 (NIVEL Zorgregistraties eerste lijn). Daarmee lijkt dit lager te liggen dan de landelijke incidentie van 4,6. De incidentieschatting van 3,0 komt overeen met 300 huisartsbezoeken per 100.000 inwoners. Uitgaande van 821.752 inwoners van de gemeente

\footnotetext{
12 De incidentieschatting voor Amsterdam is in 2010 en 2011 gebaseerd op een vrij kleine steekproef uit de huisartspraktijken.
} 
Amsterdam in 2015, betreft dit bijna 2.500 mensen die zich in dat jaar meldden bij de huisarts na door een hond gebeten te zijn.

In figuur 12 staan de incidentieschattingen per jaar in 2010 tot en met 2015 in Amsterdam. In figuur 13 staan de incidentieschattingen voor mannen en vrouwen per leeftijdscategorie in 2015. Hieruit blijkt dat vooral jonge kinderen en vrouwen van 25 jaar en ouder zich bij de huisarts melden na een beet.

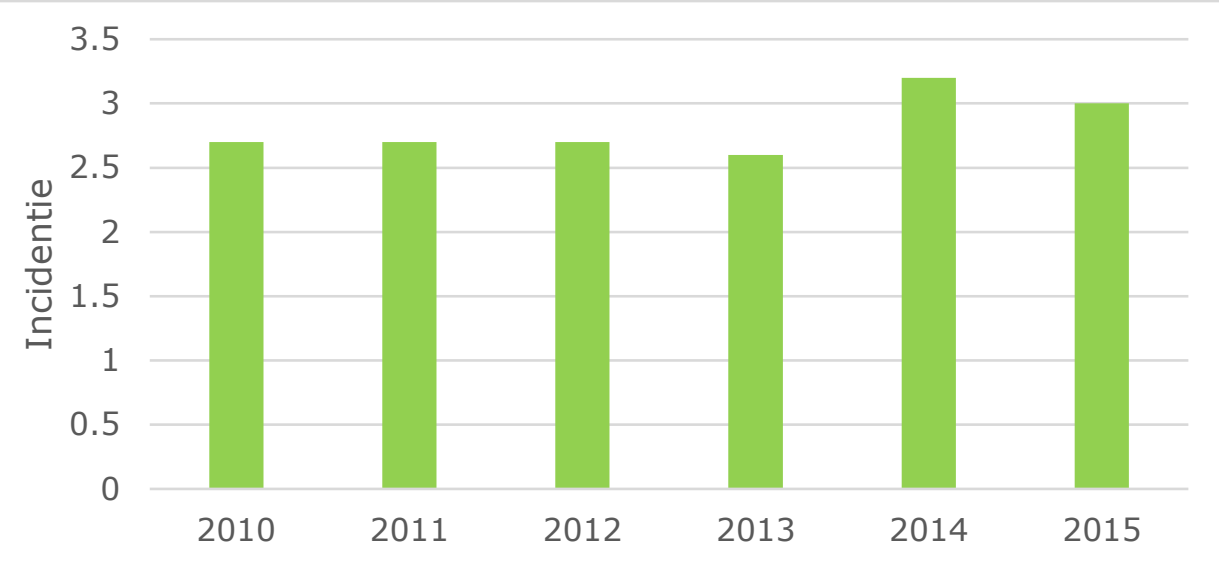

Figuur 12 Incidentieschatting (aantal per 1.000 persoonsjaren) van een bezoek aan de huisarts na een beet mens/dier in Amsterdam per jaar in 2010 tot en met 2015 (bron: NIVEL Zorgregistraties eerste lijn)

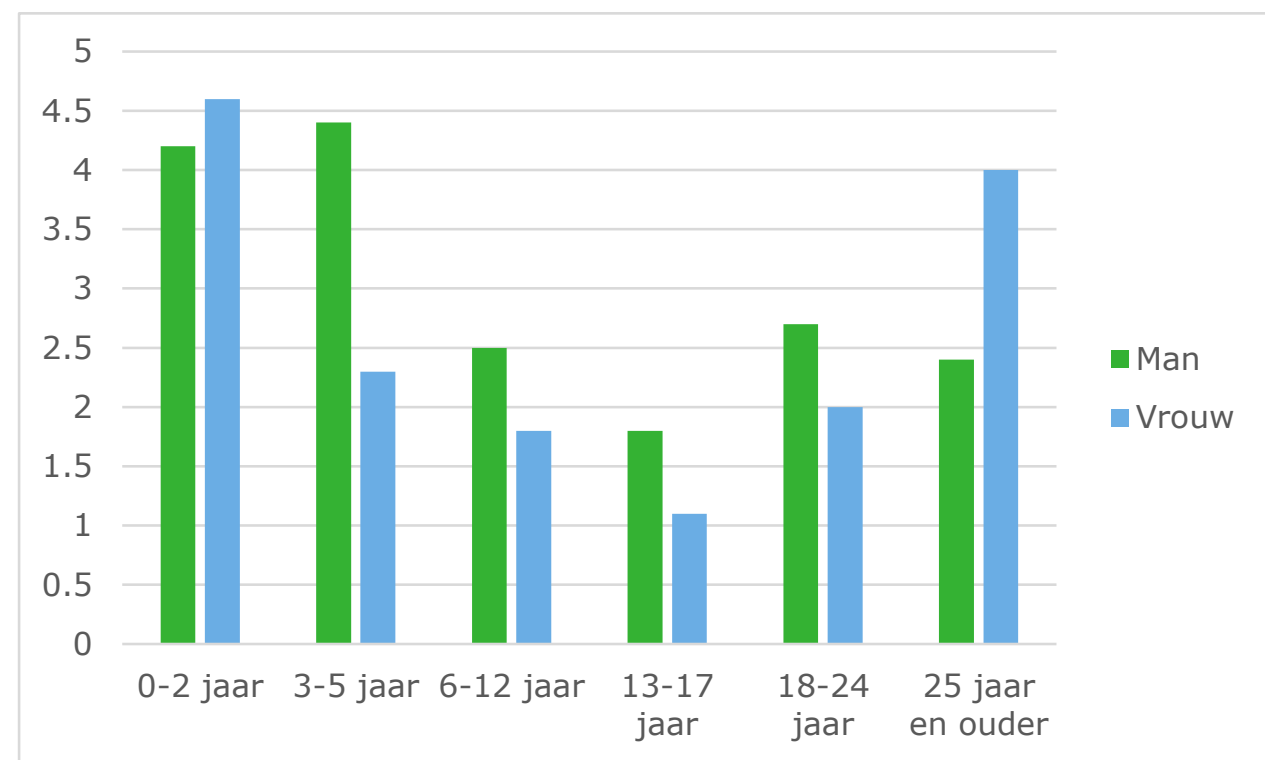

Figuur 13 Incidentieschatting (aantal per 1.000 persoonsjaren) van een bezoek aan de huisarts na een beet mens/dier in Amsterdam in 2015 voor mannen en vrouwen per leeftijdscategorie (bron: NIVEL Zorgregistraties eerste lijn)

\subsection{Behandeling bij de spoedeisende hulp}

Om het aantal slachtoffers van een bijtincident in Amsterdam dat zich meldt bij het ziekenhuis te bepalen zou data van alle Amsterdamse ziekenhuizen beschikbaar moeten zijn. Via VeiligheidNL zijn alleen data van twee Amsterdamse ziekenhuizen (VUmc en het Academisch Medisch Centrum (AMC)) beschikbaar. Deze cijfers geven dan ook geen totaal beeld, maar zijn illustratief. In de twee ziekenhuizen VU en AMC te Amsterdam werden in 201575 SEH-bezoeken geregistreerd waarbij het slachtoffer letsel had opgelopen in verband met een bijtincident door toedoen van een hond (VeiligheidNL, 2017). Dit komt overeen met 9,1 SEH-bezoeken per 100.000 inwoners van de gemeente Amsterdam. 
In 2010 lag het aantal geregistreerde SEH-bezoeken bij de VU en het AMC op 153 (overeenkomend met 19,9 SEH-bezoeken per 100.000 inwoners; zie figuur 14).

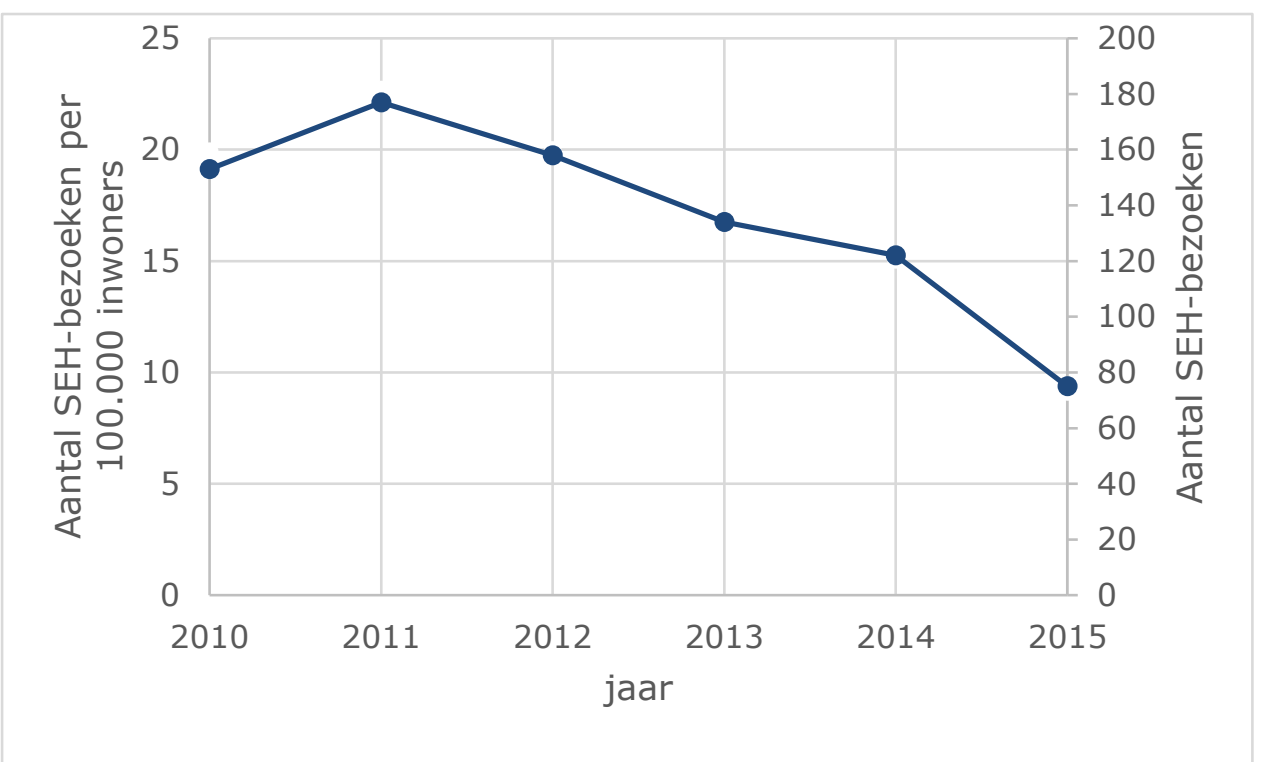

Figuur 14 Aantal SEH-bezoeken en aantal SEH-bezoeken per 100.000 inwoners na bijtincidenten in Amsterdam 2010-2015 (alleen academische ziekenhuizen AMC en VU) (Bron: VeiligheidNL, 2017)

Het aantal SEH-bezoeken in deze twee ziekenhuizen lijkt in de afgelopen 5 jaar af te nemen. Net als bij de landelijke aantallen, zou een mogelijke oorzaak volgens VeiligheidNL de verplaatsing van minder ernstige letsels naar huisartsen posten en huisartsenpraktijken kunnen zijn. Dit is terug te zien (zie paragraaf 5.2) in de toename in het aantal huisartsbezoeken in Nederland na een hondenbeet van 324 in 2006 naar 460 in 2015 per 100.000 inwoners. Deze stijging is minder goed te zien in de data van de Amsterdamse huisartsen (zie paragraaf 6.2).

\subsection{Opname in een ziekenhuis}

In 2015 werd in Amsterdam in het VU en AMC slechts 1 slachtoffer geregistreerd waarbij een ziekenhuisopnamen na het SEH-bezoek noodzakelijk was ten gevolge van letsel door een bijtincident met een hond (VeiligheidNL, 2017). Dit zou overeenkomen met $\mathbf{0 , 1 2}$ ziekenhuisopnames (in AMC en VU) per 100.000 inwoners, maar aangezien ziekenhuisopnames in Amsterdam in één van de andere ziekenhuizen niet zijn meegenomen, is dit niet het volledige beeld.

In de jaren 2010-2015 lag dit aantal iets hoger, variërend tussen 4 en 6 ziekenhuisopnamen, overeenkomend met $\mathbf{0 , 6}$ ziekenhuisopnames (in AMC en VU) per 100.000 inwoners. Echter, doordat het kleine aantallen betreft kunnen hieruit geen conclusies worden getrokken met betrekking tot een mogelijke trend.

\subsection{Behandeling bij een dierenarts}

Via de afdeling chirurgie van de spoedkliniek van het Medisch Centrum voor Dieren in Amsterdam (MCD-AniCura) zijn gegevens bekend over het aantal patiënten waarvoor na een bijtincident diergeneeskundige hulp is ingeroepen. MCD-Unicura is hiervoor 24/7 beschikbaar. MCD-Unicura geeft aan dat de meeste bijttrauma's via de eerstelijns spoedartsen zijn doorverwezen. Vanaf 2013 tot half November 2017 zijn er 33 patiënten aangeboden. Dit betreft die dieren die de operatiekamer haalden. Een onbekend aantal eerder overleden dieren zijn hierin niet inbegrepen. Bovendien zijn honden die door de eerstelijns spoedartsen van het MCD zijn behandeld ook niet meegeteld. Honden met kleinere verwondingen waarvoor geen specialistische zorg was vereist blijven daarmee ook buiten beeld. 


\subsection{Aantal mensen overleden aan een hondenbeet}

Een hondenbeet met dodelijk afloop komt in Nederland relatief weinig voor, dit treft jaarlijks geen enkel, één of hooguit twee personen. Het is niet bekend, maar aannemelijk, dat fatale bijtincidenten in Amsterdam vrijwel niet voorkomen.

\subsection{Aantal dieren overleden aan een hondenbeet}

Het aantal dieren dat in Amsterdam jaarlijks overlijdt als gevolg van een hondenbeet is onbekend. Dit wordt immers niet structureel bijgehouden. In de 441 geanalyseerde politieregistraties (zie §6.1) van hondenbeten is het slachtoffer in $47 \%$ van de bijtincidenten een andere hond en in $8 \%$ van de incidenten een ander dier. Als we inzoomen op de dodelijke dierlijke slachtoffers dan betrof dit in de periode 2015 tot en met 14 oktober 201712 katten, 12 kleine hondjes (Chihuahua, Pinscher, Shih tzu, Maltezer), éénmaal een konijn en éénmaal een gans. Eénmaal overleed een grote hond daags nadat deze bij een bijtincident door een andere grote hond was besprongen.

\subsection{Ras(type) hond die heeft gebeten}

Van de 441 bij de politie geregistreerde bijtincidenten (zie ook §6.1) is getracht het ras/type van de hond die beet (inclusief dreigde te bijten) te achterhalen. Bij 83\% van de incidenten was dit vermeld. Groepen die eruit sprongen waren de Pitbullachtigen $(n=190)$, de Herderachtigen $(n=55)$ en in mindere mate de Rottweiler $(n=12)$, alle inclusief kruisingen (zie figuur 15). Onder het PSB-cluster zijn op basis van de beschrijvingen van de politie honden geclusterd en als volgt aangeduid: Amerikaanse buldog (14), Amerikaanse pitbull (3), Amerikaanse staffordshireterriër (50), Bulterriër (3), Staffordshire-bulterriër (2), Staffordachtigen $(n=20)$ en Pitbullachtigen $(n=98)$. Het is niet uit te sluiten dat door identificatieproblemen en onvolledige beschrijvingen van de betrokken honden de verdeling binnen het PSB-cluster tot op zekere hoogte discutabel is. Van 76 honden was het ras of type niet nader gespecificeerd.

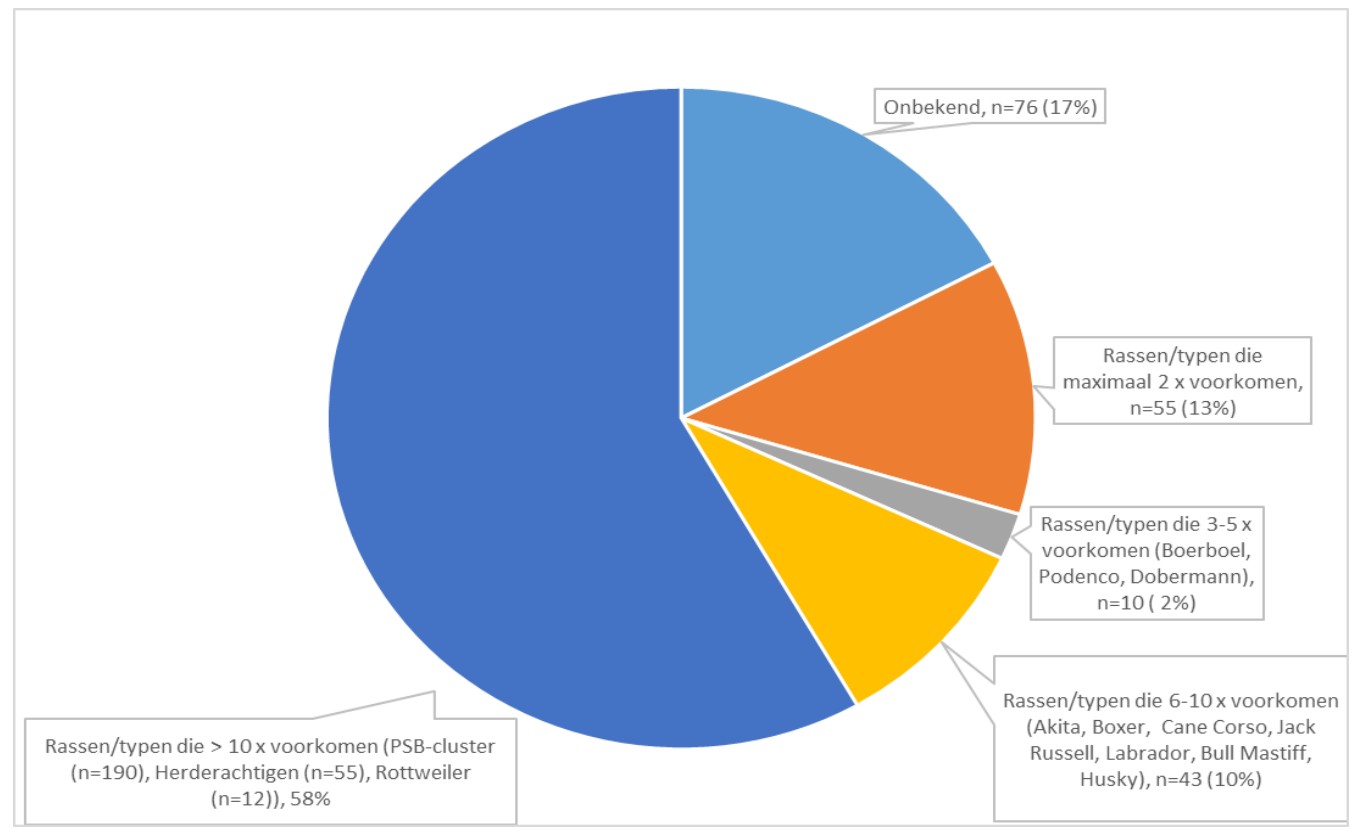

Figuur 15 Verdeling naar ras of type van honden die als agressor vermeld zijn bij door de politie geregistreerde bijtincidenten in de gemeente Amsterdam in de periode 2015-2017 (t/m 14 oktober; $n=441$ ) 


\subsection{Ernst en toedracht van bijtincidenten}

De begeleider/eigenaar van de hond die als agressor betrokken was bij een bijtincident was in $56 \%$ van de gevallen een man, in 34\% een vrouw en bij $10 \%$ van de registraties niet vermeld (uit meldingen bij de politie, zie §6.1). De hond die beet was in 57\% van de gevallen niet aangelijnd, bij $22 \%$ van de bijtincidenten was de hond aangelijnd. Voor de overige $21 \%$ van de incidenten was dit niet geregistreerd.

Over het algemeen veroorzaakten aangelijnde honden bij het slachtoffer minder schade dan honden die niet waren aangelijnd (figuur 16). Bij in totaal 63 van de 441 bijtincidenten was de hond ontsnapt uit een tuin, woning of auto of was deze losgebroken. Bij 63 bijtincidenten was er geen sprake van toezicht, in 21 gevallen omdat de hond was ontsnapt of los liep op het eigen terrein. Bij 40 bijtincidenten kon de eigenaar van de hond niet worden achterhaald of verbleef deze in het buitenland. In 11 gevallen liep de hond los in de wijk. Bij 19 bijtincidenten is aangegeven dat de schade door betrokkenen onderling wordt geregeld.

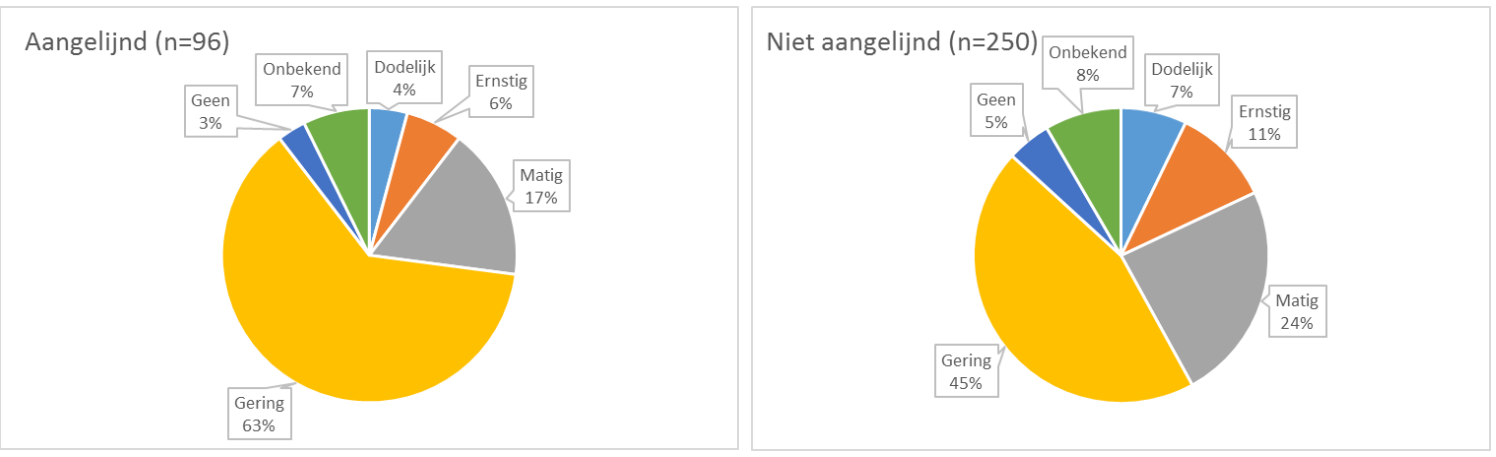

Figuur 16 Letselschade bij slachtoffers van door de politie geregistreerde bijtincidenten in de gemeente Amsterdam in de periode 2015-2017 (t/m 14 oktober; $n=441$ ) voor agressors die al (links) dan niet (rechts) waren aangelijnd

In de 441 geanalyseerde registraties van hondenbeten is het slachtoffer in $47 \%$ van de bijtincidenten een andere hond, in 37\% van de incidenten een mens, in $8 \%$ van de incidenten een ander dier of zijn zowel mens als dier slachtoffer van het incident (8\%). Dergelijke situaties doen zich voor als mensen bijvoorbeeld vechtende honden uit elkaar willen halen.

De ernst van het letsel dat bij een bijtincident is aangebracht verschilt per slachtoffercategorie (figuur 17). Bijtincidenten in de gemeente Amsterdam die bij de politie zijn geregistreerd bleken voor menselijke slachtoffers niet fataal, maar voor (vooral kleine) honden en andere dieren (voornamelijk katten) hadden deze in respectievelijk $6 \%$ en $43 \%$ wel de dood tot gevolg. Het beeld dat het formaat van het slachtoffer debet is aan de aangerichte schade, wordt bevestigd in de letselcategorie 'Gering'. Bij mensen leidden bijtincidenten in $62 \%$ van de gevallen tot gering letsel, bij honden en andere dieren was dit respectievelijk $46 \%$ en $14 \%$. 

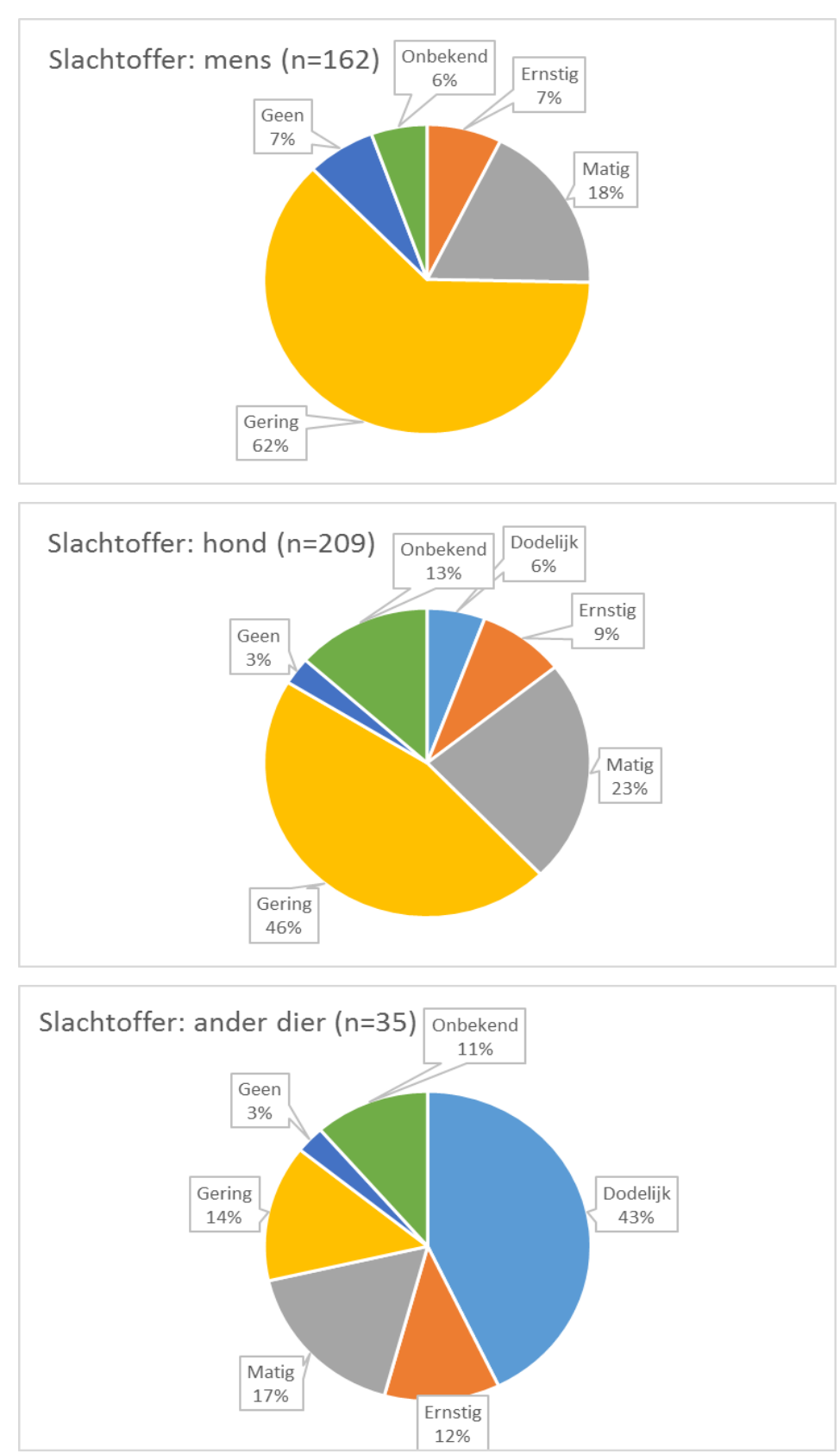

Figuur 17 Letselschade bij slachtoffers van door de politie geregistreerde bijtincidenten in de gemeente Amsterdam in de periode 2015-2017 ( $t / m$ oktober; $n=441$ ) voor de slachtoffer categorieën mens, hond en ander dier

\subsection{In beslag genomen honden}

Navraag bij de Dierenopvang Amsterdam (DOA) leert dat het niet goed mogelijk is om informatie te krijgen over de honden (aantallen en rassen/typen) die in de gemeente Amsterdam in beslag zijn genomen. In de eerste plaats omdat niet alle honden die in Amsterdam in beslag worden genomen, bij de DOA in opslag worden gegeven. Deze worden verdeeld over meerdere opslaghouders. Ten tweede omdat in het registratiesysteem van de DOA niet kan worden geselecteerd op uitsluitend honden die in de gemeente Amsterdam in beslag zijn genomen. 


\section{$7 \quad$ Aanpak bijtincidenten elders}

Wetgeving op het gebied van zogenaamde hoog-risico of gevaarlijke honden verschilt van land tot land. In tabel 12 staat een overzicht van de wetgeving in de ons omringende landen.

Tabel 12 Rasgebonden aanpak van bijtincidenten in enkele Europese landen

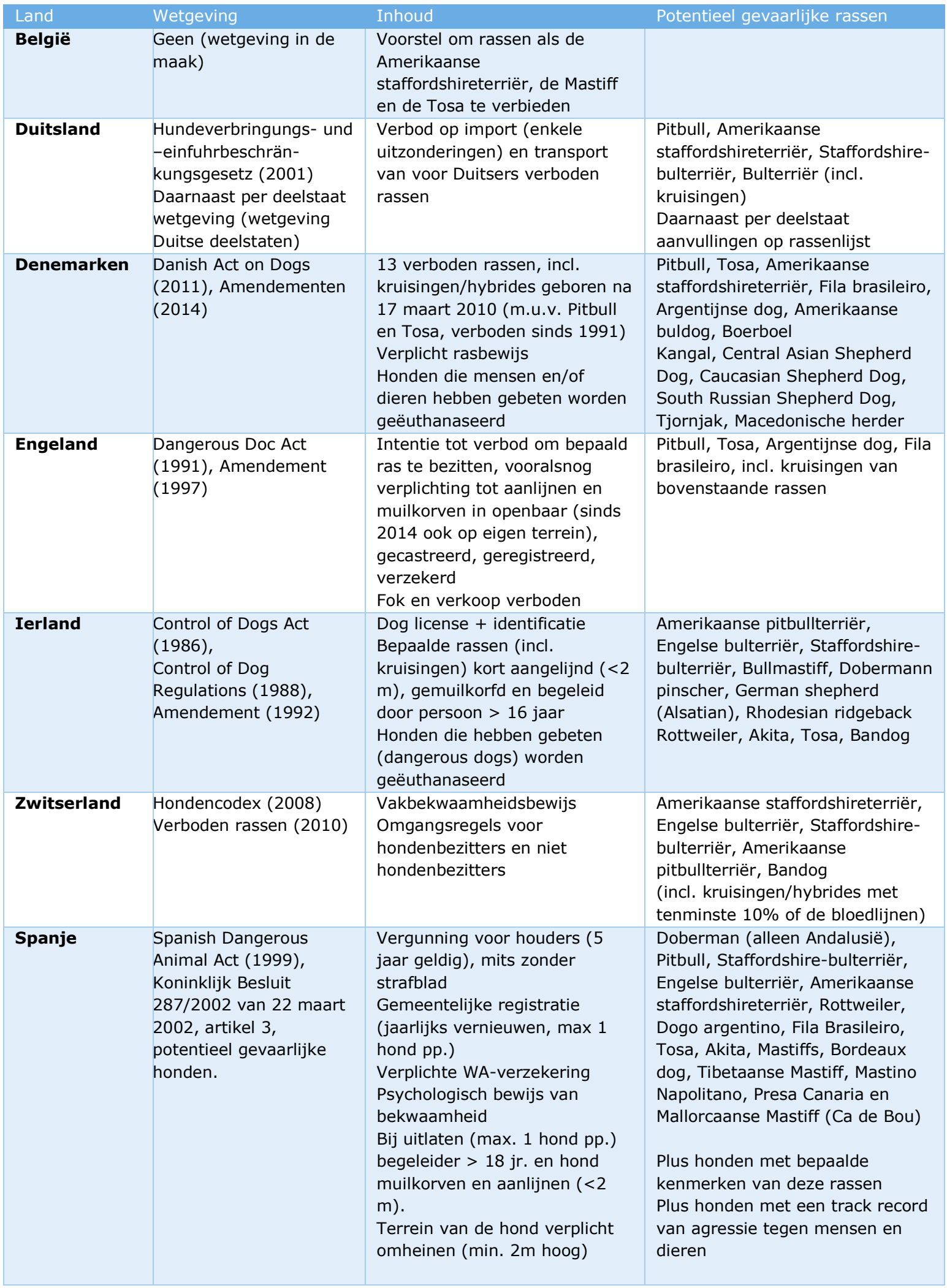


De effectiviteit van wetgeving op het gebied van bijtincidenten is voor een aantal landen geëvalueerd. In tabel 13 staat de daarover gevonden literatuur samengevat. Daaruit kan niet worden geconcludeerd dat het instellen van rasgebonden regelgeving, waarin bepaalde "bijtgevaarlijke" hondenrassen worden verboden of hun vrijheid wordt ingeperkt, altijd tot een gewenste vermindering van hondenbeten heeft geleid. In Ierland, Schotland, Spanje (Aragón), Australië en Duitsland (Nierdersaksen) leidde dit niet tot minder hondenbeten. Dit komt overeen met de conclusies van Cornelissen en Hopster (2010) over de effectiviteit van de Regeling Agressieve Dieren in Nederland. In Canada en Spanje (Catalonië) werd wel een afname gemeld. Conclusies over effecten van repressieve maatregelen blijven echter met veel onzekerheid omgeven omdat goede controles vaak ontbreken en het effect van de maatregel als zodanig wordt beïnvloed door tal van andere factoren, onder andere de mate van en het budget voor handhaving.

De objectieve veiligheid op basis van het feitelijke risico door een hond gebeten te worden staat overigens (gedeeltelijk) los van de subjectieve veiligheid, i.e. het gevoel van veiligheid dat burgers in de publieke ruimte ervaren. Uit tabel 10 wordt ook duidelijk dat waar er sprake is van rasgebonden regelgeving, deze met name is gericht op bepaalde rassen/typen en dat daarover tussen wetgevers in verschillende landen blijkbaar gedeeltelijk overeenstemming is. Het is daarom niet uit te sluiten dat genoemde hoog risico rassen/typen weliswaar niet substantieel bijdragen aan de aard en omvang van de hondenbetenproblematiek, maar dat hoog risico honden juist wel door bepaalde eigenaren in een bepaalde context worden gehouden (Barnes et al., 2006; Duijnker, 2016), en vooral het samenspel van deze factoren bij de burger het gevoel van onveiligheid versterkt. En daarmee de beeldvorming over de gevaarlijke eigenschappen van honden van bepaalde rassen/typen. Met de subjectieve veiligheid als vertrekpunt kunnen mogelijk andere conclusies worden getrokken.

\section{Alternatieven:}

Ó Súilleabháin (2015) benadrukt dat bijtincidenten niet alleen door zogenaamde 'vechtrassen' worden veroorzaakt, maar ook door andere rassen, waaronder 'toy rassen'. Honden van rassen die in Ierland worden aangemerkt als hoog risico rassen vertoonden geen hoger agressie niveau dan honden van andere rassen. Hij beveelt daarom 'non-breed specific' regelgeving aan en voorlichting en onderwijsprogramma's gericht op kinderen.

Ook Bandow (1996) onderschrijft dat alle honden kunnen bijten en niet specifiek alleen de Pitbulls. Klaassen et al., 1996 rapporteert dat zowel voor als na inwerkingtreding van "the Dangerous Dog Act" de rassen betrokken bij hondenbeten dezelfde zijn gebleven, echter alleen in andere volgorde: te weten voor de Dangerous Dog Act waren het voornamelijk Duitse herders gevolgd door bastaards en na de Dangerous Dog Act waren het bastaards gevolgd door de Duitse herders. De gevaarlijke rassen zoals aangegeven in de Act waren in totaal slechts voor 6,1\% verantwoordelijk voor de hondenbeten die waren waargenomen. Volgens de auteurs zou de regelgeving voor een groter aantal rassen moeten gelden en niet alleen voor de gevaarlijke rassen zoals aangegeven in "the Dangerous Dogs Act" 1991.

Ledger et al., (2005) schreef een overzichtsverhaal dat in gaat op evaluatie van de effectiviteit van ras specifieke regelgeving en doet aanbevelingen voor alternatieven naar aanleiding van het in Ontario aannemen van de Dog Owners Liability act in 2005. Zij plaatsten kanttekeningen bij de evaluatie van de effectiviteit van regelgeving omdat naast de betreffende regelgeving vaak ook andere maatregelen worden genomen, zoals voorlichting, onderwijs en een campagne. De auteurs noemen andere strategieën/alternatieven die in hun ogen beter gevolgd kunnen worden dan het instellen van een verbod op gevaarlijke honden, te weten: uitsluiten van agressieve honden in de fokkerij, het goed socialiseren van puppies, zorg dragen voor een goede opvoeding van en omgang met volwassen honden. Bij honden die meer beweging krijgen is volgens Ledger et al (2005) de prevalentie van bijtincidenten kleiner en honden die goed onder appél staan veroorzaken minder bijtincidenten.

Ook Bradley (2014) onderschrijft dat door het instellen van Breed Specific Legislation het aantal bijtincidenten niet vermindert, gebaseerd op gegevens in de UK en in verschillende staten in de USA en Canada. Hij doet een aantal aanbevelingen om hondenbeten tegen te gaan: "Dangerous Dog" laws, waarin honden die gebeten hebben als gevaarlijk worden aangemerkt en waarbij de eigenaar maatregelen opgelegd krijgt zoals: het verplicht (kort) aanlijnen, muilkorven buiten eigen terrein, training, consultatie van een hondengedragsdeskundige en de hond op straat alleen door personen ouder dan 18 jaar laten begeleiden. Probleem blijft hoe je hondenbeten kunt voorkomen door vooraf al in te schatten welke honden gaan bijten.

Aanbevolen wordt om met name "responsible dog guardianship" aan te moedigen. Gebleken is dat hiermee het aantal hondenbeten drastisch kan worden verminderd. Aangegeven wordt dat onder responsible dog guardianship onder andere wordt verstaan het bij de eigenaar bevorderen en 
ondersteunen van verantwoordelijk gedrag, waaronder goede voeding, adequate diergeneeskundige zorg, socialisatie en training, registratie van de honden en aanlijn geboden. M.a.w. er voor te zorgen dat de honden geen gevaar worden voor de gemeenschap. Als voorbeeld noemt hij Calgary, Alberta (Canada) waar met een dergelijke wetgeving het aantal gerapporteerde hondenbeten daalde van 621 in 1985 naar 200 in 2008. Deze regels gelden in Galgary voor alle honden. Het instellen van een strikt aanlijn gebod met forse boetes voor het niet aanlijnen lijkt daar effectief. In een studie uit 2009 in Canada onder 36 gemeenten werden in de gemeente met de meeste boetes het minste aantal gerapporteerde hondenbeten aangetroffen (boetes met name op niet aanlijnen en niet op eigen terrein houden van de hond). Een studie in Europa (2003) naar hondenbeten bij kinderen liet zien dat hondenbeten die optraden tussen een onbekende hond en kind buiten het eigen huis voorkomen hadden kunnen worden als de honden aangelijnd waren geweest. Het onder curatele stellen van honden die mensen hebben verwond lijkt Bradley (2014) beter haalbaar dan een meer algemene regelgeving zoals de ras specifieke regelgeving. Op deze manier kan de (honden)politie volgens hem effectiever ingezet worden. 
Tabel 13 Een beknopt overzicht van de resultaten van onderzoek naar de effectiviteit van regelgeving gericht op het verminderen van hondenbeten

\begin{tabular}{|c|c|c|c|c|c|c|c|c|}
\hline Auteur & Land & Regelgeving & Rassen & Methode/Waarnemingen & $\begin{array}{l}\text { Controle } \\
\text { groep }\end{array}$ & Periode & Uitkomst & Effectief \\
\hline $\begin{array}{l}\text { Creedon and ó } \\
\text { Súilleabháin, } \\
2017\end{array}$ & Ierland & $\begin{array}{l}\text { Control of Dogs Act } \\
(1986), \\
\text { Control of Dog } \\
\text { Regulations (1988), } \\
\text { Amendement (1992) }\end{array}$ & $\begin{array}{l}\text { Duitse herder, Rottweiler, } \\
\text { Amerikaanse } \\
\text { staffordshireterriër, Akita, } \\
\text { Dobermann pincher } \\
\text { rashonden vergeleken met } \\
\text { niet geregistreerde } \\
\text { rashonden }\end{array}$ & $\begin{array}{l}\text { Vragenlijst } \\
40 \text { hondenbeten door } \\
\text { honden van geregistreerde } \\
\text { rassen }\end{array}$ & $\begin{array}{l}100 \\
\text { hondenbeten } \\
\text { door niet- } \\
\text { geregistreerde } \\
\text { rassen }\end{array}$ & $\begin{array}{l}\text { Tot } \\
\text { maart } \\
2016\end{array}$ & $\begin{array}{l}\text { Geen verschil tussen } \\
\text { geregistreerde en niet } \\
\text { geregistreerde rassen } \\
\text { voor leeftijd slachtoffer, } \\
\text { waar gebeten, relatie } \\
\text { met dader, ernst beet }\end{array}$ & $\begin{array}{l}\text { Nee } \\
\text { Wel invloed op } \\
\text { perceptie van } \\
\text { risico op beet } \\
\text { door } \\
\text { geregistreerde } \\
\text { rassen }\end{array}$ \\
\hline $\begin{array}{l}\text { Ó Súilleabháin, } \\
2015\end{array}$ & Ierland & $\begin{array}{l}\text { Control of Dogs Act } \\
(1986), \\
\text { Control of Dog } \\
\text { Regulations (1988), } \\
\text { Amendement (1992) }\end{array}$ & $\begin{array}{l}\text { Specifieke rassen ( } 11 \text { totaal, } \\
\text { waaronder hybrides) }\end{array}$ & $\begin{array}{l}\text { Aantal mensen dat met } \\
\text { bijtwonden is behandeld in } \\
\text { het ziekenhuis }\end{array}$ & nee & $\begin{array}{l}1998- \\
2013\end{array}$ & $\begin{array}{l}\text { Aantal bijt incidenten } \\
\text { neemt significant toe per } \\
\text { jaar met } 1,5 \%\end{array}$ & Nee \\
\hline $\begin{array}{l}\text { Raghavan et } \\
\text { al., } 2013\end{array}$ & $\begin{array}{l}\text { Canada, } \\
\text { Manitoba }\end{array}$ & $\begin{array}{l}\text { Verbannen van Pitbull } \\
\text { (terriër) type honden uit } \\
\text { de steden (breed specific } \\
\text { legislation BSL), van } \\
\text { kracht in } 1990\end{array}$ & $\begin{array}{l}\text { Pitbull, } \\
\text { Amerikaanse } \\
\text { staffordshireterriër, } \\
\text { Amerikaanse pitbullterriër } \\
\text { en andere type honden die } \\
\text { hierop lijken. }\end{array}$ & $\begin{array}{l}\text { Hondenbeten die leiden tot } \\
\text { behandeling in het } \\
\text { ziekenhuis per } 100.000 \\
\text { inwoners tijdens de } \\
\text { onderzoeksperiode in } \\
\text { Winnipeg (met } \\
\text { regelgeving) en Bandon } \\
\text { (zonder regelgeving) }\end{array}$ & $\begin{array}{l}\text { Stad zonder } \\
\text { regelgeving }\end{array}$ & $\begin{array}{l}1984- \\
2006\end{array}$ & $\begin{array}{l}\text { Daling van aantal bijt } \\
\text { incidenten van } 3.62 \text { naar } \\
2.92 \text { per } 100.000 \\
\text { inwoners } \\
\text { (voornamelijk personen } \\
<20 \text { jaar) }\end{array}$ & $\mathrm{Ja}^{1}$ \\
\hline $\begin{array}{l}\text { Clarke and } \\
\text { Fraser, } 2013\end{array}$ & Canada & $\begin{array}{l}\text { Verschillende } \\
\text { maatregelen: } \\
\text { Registratie plicht, boetes, } \\
\text { budget aan dieren } \\
\text { controle diensten, aantal } \\
\text { mensen in dienst tbv } \\
\text { controle, voorlichting }\end{array}$ & Niet specifiek benoemd & $\begin{array}{l}\text { Vragenlijst } \\
\text { Aantal gerapporteerde bijt } \\
\text { incidenten naar } \\
\text { overheidsinstanties per } \\
10.000 \text { personen }\end{array}$ & Nee & 2005 & $\begin{array}{l}\text { Meer boetes en } \\
\text { registratie leidde tot } \\
\text { lager bijtincidentie als } \\
\text { verwacht volgens lineaire } \\
\text { trend }\end{array}$ & $\mathrm{Ja}$ \\
\hline $\begin{array}{l}\text { Klaassen et al., } \\
1996\end{array}$ & Schotland & $\begin{array}{l}\text { Dangerous Dog Act } \\
\text { (1991) }\end{array}$ & Alle rassen & $\begin{array}{l}\text { Vragenlijst } \\
\text { alle bijtincidenten door } \\
\text { zoogdieren (honden, } \\
\text { mensen, knaagdieren etc.) }\end{array}$ & nee & $\begin{array}{l}\text { Okt-Dec } \\
1991 \\
\text { (voor) } \\
\text { en Nov- } \\
\text { Jan } 1994 \\
\text { (na) }\end{array}$ & $\begin{array}{l}\text { Voor: } 99 \text { bijtincidenten } \\
\text { waarvan } 73.9 \% \\
\text { veroorzaakt door } \\
\text { honden. Na: } 99(73.1 \%) \\
\text { veroorzaakt door honden } \\
\text { In beide gevallen een } \\
\text { derde bij mensen }<15 \\
\text { jaar) }\end{array}$ & Nee \\
\hline
\end{tabular}




\begin{tabular}{|c|c|c|c|c|c|c|c|c|}
\hline Auteur & Land & Regelgeving & Rassen & Methode/Waarnemingen & $\begin{array}{l}\text { Controle } \\
\text { groep }\end{array}$ & Periode & Uitkomst & Effectief \\
\hline Bandow, 1996 & Canada & n.v.t. & Alle rassen & $\begin{array}{l}\text { Overzicht van } \\
\text { geregistreerde } \\
\text { bijtincidenten per ras } \\
\text { geregistreerd door de } \\
\text { Toronto Department of } \\
\text { Public Health. Het totaal } \\
\text { aantal bijtincidenten in } \\
1993 \text { bedroeg } 628\end{array}$ & n.v.t. & 1993 & $\begin{array}{l}\text { Niet specifieke rassen, } \\
\text { Duitse herder of kruising } \\
\text { Duitse herders en Collie } \\
\text { rassen } 42 \% \text { van de } \\
\text { incidenten t.o.v. } 9,5 \% \\
\text { door Pitbulls en kruising } \\
\text { PitBulterriërs }\end{array}$ & n.v.t. \\
\hline Collier, 2006 & Australië & $\begin{array}{l}\text { Commonwealth (1991) } \\
\text { waarin ras specifieke } \\
\text { beperkingen voor de } \\
\text { Amerikaanse pitbull zijn } \\
\text { opgenomen }\end{array}$ & Pitbull & $\begin{array}{l}\text { Overzicht van } 829 \\
\text { geregistreerde } \\
\text { bijtincidenten, waarvan } 33 \\
\text { door Amerikaanse } \\
\text { pitbullterriër ( } 1 \% \text { van de } \\
\text { geregistreerde terriërs) }\end{array}$ & & $\begin{array}{l}1997- \\
2000\end{array}$ & $\begin{array}{l}\text { Geen bewijs voor een } \\
\text { daling van het aantal } \\
\text { bijtincidenten door } \\
\text { Pitbull }\end{array}$ & Nee \\
\hline $\begin{array}{l}\text { Villalbi et al., } \\
2010\end{array}$ & $\begin{array}{l}\text { Spanje, } \\
\text { Catalonië }\end{array}$ & $\begin{array}{l}\text { Spanish Dangerous } \\
\text { Animal Act (1999), } \\
\text { Koninklijk Besluit } \\
287 / 2002 \text { van } 22 \text { maart } \\
\text { 2002, artikel 3, } \\
\text { potentieel gevaarlijke } \\
\text { honden. }\end{array}$ & $\begin{array}{l}\text { Pitbull, Staffordshire- } \\
\text { bulterriër, Amerikaanse } \\
\text { staffordshireterriër, } \\
\text { Rottweiler, Bullmastiff, } \\
\text { Mastino napoletano, } \\
\text { Argentina Mastiff, Bordeaux } \\
\text { Mastiff, Canary vecht hond, } \\
\text { Brazilian Fila, Dobermann, } \\
\text { Tosa, Akita en hun mixed } \\
\text { breeds en honden door } \\
\text { dierenartsen als gevaarlijk } \\
\text { verklaarde honden op basis } \\
\text { van agressie verleden. }\end{array}$ & $\begin{array}{l}\text { Hondenbeten geregistreerd } \\
\text { met speciale code in } \\
\text { ziekenhuisopnames door de } \\
\text { Catalonian Health Service } \\
\text { naar plaats (Barcelona vs. } \\
\text { de rest van Catalonië). }\end{array}$ & nee & $\begin{array}{l}1997- \\
1999 \text { vs. } \\
2006- \\
2008\end{array}$ & $\begin{array}{l}22 \% \text { verlaging van } \\
\text { geregistreerde honden } \\
\text { beten in Barcelona, en } \\
38 \% \text { verlaging voor } \\
\text { Catalonië }\end{array}$ & $\begin{array}{l}\text { Ja, regelgeving } \\
\text { kan bijgedragen } \\
\text { hebben aan } \\
\text { vermindering } \\
\text { van } \\
\text { bijtincidenten }\end{array}$ \\
\hline $\begin{array}{l}\text { Rosado et al., } \\
2007\end{array}$ & $\begin{array}{l}\text { Spanje, } \\
\text { Aragón }\end{array}$ & $\begin{array}{l}\text { Spanish Dangerous } \\
\text { Animal Act (1999), } \\
\text { Koninklijk Besluit } \\
287 / 2002 \text { van } 22 \text { maart } \\
\text { 2002, artikel 3, } \\
\text { potentieel gevaarlijke } \\
\text { honden. }\end{array}$ & $\begin{array}{l}\text { Pitbull, Staffordshire- } \\
\text { bulterriër, Amerikaanse } \\
\text { staffordshireterriër, } \\
\text { Rottweiler, Argentino Dogo, } \\
\text { Brazilian Fila, Tosa, Akita. }\end{array}$ & $\begin{array}{l}\text { Hondenbeten die medisch } \\
\text { zijn behandeld en } \\
\text { gerapporteerd aan Public } \\
\text { Health Department in } \\
\text { Aragon ( } 3 \text { provincies) } \\
\text { onderverdeeld naar hoog } \\
\text { en laag bezette gebieden. } \\
\text { Honden zijn geregistreerd } \\
\text { met tax code gekoppeld } \\
\text { aan verplichte jaarlijkse } \\
\text { rabiës vaccinatie }\end{array}$ & $\begin{array}{l}\text { Bepaalde } \\
\text { cross-breed } \\
\text { groepen zijn } \\
\text { in onderzoek } \\
\text { opgenomen: } \\
\text { kruisingen } \\
\text { met Duitse } \\
\text { herder, Mastiff } \\
\text { en de } \\
\text { genoemde } \\
\text { gevaarlijke } \\
\text { rassen. }\end{array}$ & $\begin{array}{l}1995- \\
1999 \text { vs. } \\
2000- \\
2004\end{array}$ & $\begin{array}{l}\text { De rassen die de meeste } \\
\text { bijtincidenten } \\
\text { veroorzaakten } \\
\text { behoorden niet tot de } \\
\text { 'gevaarlijke } \\
\text { hondenrassen. De } \\
\text { gevaarlijke } \\
\text { hondenrassen droegen } \\
\text { slechts in beperkte mate } \\
(5,3 \%) \text { bij aan } \\
\text { bijtincidenten. } 7 \text { rassen } \\
\text { betrokken in } 70 \% \text { van de }\end{array}$ & Nee \\
\hline
\end{tabular}




\begin{tabular}{|c|c|c|c|c|c|c|c|c|}
\hline Auteur & Land & Regelgeving & Rassen & Methode/Waarnemingen & $\begin{array}{l}\text { Controle } \\
\text { groep }\end{array}$ & Periode & Uitkomst & Effectief \\
\hline & & & & & $\begin{array}{l}\text { In totaal } 32 \\
\text { rassen (meest } \\
\text { populaire, } \\
90 \% \text { van alle } \\
\text { geregistreerde } \\
\text { honden) }\end{array}$ & & $\begin{array}{l}\text { bijtincidenten waaronder } \\
\text { de herders en zijn } \\
\text { kruisingen (resp. } 38,3 \text { en } \\
34,7 \% \text { ) voor en } \\
\text { inwerkingtreding } \\
\text { regelgeving. }\end{array}$ & \\
\hline $\begin{array}{l}\text { Schalke et al., } \\
2008\end{array}$ & $\begin{array}{l}\text { Nedersak } \\
\text { sen } \\
\text { (Duitslan } \\
\text { d) }\end{array}$ & $\begin{array}{l}\text { Niedersaechsische } \\
\text { Gefahrtierverordnung; } \\
\text { Wetgeving die het } \\
\text { houden van specifieke } \\
\text { hondenrassen beperkt } \\
\text { Ingaande Juli } 2000 \\
\text { Uitzondering was } \\
\text { mogelijk na goed } \\
\text { doorlopen van } \\
\text { specifieke test }\end{array}$ & $\begin{array}{l}\text { Amerikaanse } \\
\text { staffordshireterriër, } \\
\text { Bulterriërs, Pitbull en } 11 \\
\text { andere rassen }\end{array}$ & $\begin{array}{l}\text { Gedragstest uitgevoerd bij } \\
415 \text { honden }\end{array}$ & & N.v.t. & $\begin{array}{l}95 \% \text { van de honden } \\
\text { reageerden normaal in } \\
\text { de test. } 5 \% \text { reageerde } \\
\text { agressief in ongepaste } \\
\text { situaties. Er werd geen } \\
\text { significant verschil } \\
\text { tussen rassen } \\
\text { aangetroffen }\end{array}$ & $\begin{array}{l}\text { Er zijn geen } \\
\text { indicaties van } \\
\text { gevaarlijkheid in } \\
\text { de betreffende } \\
\text { rassen. } \\
\text { Motivering voor } \\
\text { specifieke } \\
\text { raslijsten in de } \\
\text { wetgeving is niet } \\
\text { getoond. }\end{array}$ \\
\hline $\begin{array}{l}\text { Ott et al., } \\
2008 a\end{array}$ & $\begin{array}{l}\text { Nedersak } \\
\text { sen } \\
\text { (Duitslan } \\
\text { d) }\end{array}$ & $\begin{array}{l}\text { Niedersaechsische } \\
\text { Gefahrtierverordnung }\end{array}$ & & $\begin{array}{l}\text { Gedragstest uitgevoerd bij } \\
\text { Golden Retriever en } \\
\text { vergeleken met } \\
\text { gedragstest op 'gevaarlijke' } \\
\text { rassen }\end{array}$ & ja & n.v.t. & $\begin{array}{l}98.6 \% \text { van de honden } \\
\text { reageerden gepast en } \\
1,4 \% \text { vertoonde } \\
\text { agressief gedrag. Geen } \\
\text { verschil tussen golden } \\
\text { Retriever en gevaarlijke } \\
\text { rassen }\end{array}$ & $\begin{array}{l}\text { Er is geen } \\
\text { wetenschappelijk } \\
\text { basis voor } \\
\text { specifieke } \\
\text { hondenlijst. } \\
\text { Regelgeving in } \\
\text { Nedersaksen is } \\
\text { veranderd } \\
\text { waarbij de } \\
\text { rassenlijst is } \\
\text { komen te } \\
\text { vervallen }\end{array}$ \\
\hline
\end{tabular}




\section{$8 \quad$ Advies bijtprotocol Amsterdam}

\subsection{Inleiding}

Bij het opstellen van dit advies aangaande het bijtprotocol is gebruikt gemaakt van een aantal informatiebronnen: bestaande bijtprotocollen en Algemene Plaatselijke Verordeningen (APV's) van diverse Nederlandse gemeenten, wetenschappelijke en grijze literatuur en wetgeving en jurisprudentie inzake bijtincidenten. Dit advies bijtprotocol beschrijft de aanpak die door de gemeente gehanteerd kan worden in navolging op de melding of aangifte van een bijtincident. De bestuursrechtelijke en de strafrechtelijke kant van de maatregelen volgend op een bijtincident vallen buiten het bestek van onze opdracht.

Het geadviseerde bijtprotocol omvat drie onderdelen: registratie van het incident, beoordelen van de ernst van het incident en vaststellen van de maatregelen volgend op het incident. Een eenduidig registratiesysteem is essentieel om een dossier op te kunnen bouwen over de veroorzakers van bijtincidenten (zowel hond als eigenaar/houder). Door een betrouwbare registratie moet de identiteit van de bijtende hond onomstotelijk vastgesteld worden, zodat sancties opgelegd en gehandhaafd kunnen worden. Aangezien niet alleen de hond zelf een rol heeft in het ontstaan van het incident, maar ook de eigenaar en de context waarin het incident heeft plaatsgevonden, moeten zoveel mogelijk relevante gegevens hierover (gestandaardiseerd) worden vastgelegd.

De ernst van een incident kan vanuit twee kanten bekeken worden, vanuit het gedrag van de hond en vanuit de ernst van de verwonding. Tussen deze twee zit een sterke correlatie, het (bijt)gedrag van de hond in combinatie met diens formaat en bouw, bepaalt vaak de ernst van de verwonding. In de literatuur worden enkele indelingen besproken, vanuit zowel het gedrag van de hond als vanuit het aangebrachte letsel, die echter geen sterke wetenschappelijke onderbouwing kennen (bv. Dunbar scale en Maksymowicz et al. (2016)). Om de ernst van het incident op basis van het gedrag van de hond vast te kunnen stellen, is men afhankelijk van de verklaringen van betrokkenen en deze kan sterk bepaald worden door subjectiviteit of vooringenomenheid. Daarnaast zijn de (waarschuwende) signalen van de hond soms kort en daarmee makkelijk te missen. De ernst van de verwonding is een maat die na het bijtincident meer objectief vastgesteld kan worden, al of niet door een arts of een dierenarts. Het verdient aanbeveling hiervoor een eenduidige scoringssystematiek te ontwikkelen en te hanteren.

\subsection{Ernst van het letsel}

Bijtprotocollen die door veel Nederlandse gemeenten gehanteerd worden, onderscheiden de ernst van het incident in twee categorieën: licht en (zeer) ernstig. Ons advies is te kiezen voor een onderverdeling in drie categorieën: licht, ernstig en zeer ernstig. Het onderscheid tussen ernstig en zeer ernstig wordt gemaakt op basis van het slachtoffer, nl. dier of mens. Dit onderscheid is noodzakelijk, omdat bij een aanval van een mens met ernstig letsel of de dood tot gevolg sprake is van disproportionele agressie die directe inbeslagname van de hond noodzakelijk maakt, om het risico voor de omgeving weg te nemen. Een andere reden voor de driedeling is dat de (gedrags)motivatie van de bijtende hond in de drie categorieën verschillend is en daarmee ook het risico op recidive en de te volgen aanpak. Onderverdeling in meer categorieën lijkt niet te verkiezen, doordat er enerzijds meer onduidelijkheid kan ontstaan over de juiste categorie en anderzijds de opdeling van de maatregelen in meer dan drie te volgen trajecten niet zinvol lijkt (op basis van het gedrag van de hond).

Bij een licht incident is sprake van een uitval van de hond die dient als waarschuwing, wat geïnitieerd kan worden door het overschrijden van de grenzen van de hond. Denk daarbij aan kinderen die de slapende hond onverhoeds benaderen of aan dominantieagressie tussen honden onderling. Het slachtoffer kan daarbij al of niet daadwerkelijk geraakt worden door de tanden maar duidelijk is dat er (nog) sprake is van een bijtrem. Indien echter geen maatregelen genomen worden om dit gedrag te voorkomen, kan een bekrachtiging plaatsvinden. Het slachtoffer trekt zich terug en de hond kan het gedrag als een succesvolle strategie gaan ervaren. Dit is de reden dat bij herhaling van een licht incident binnen een periode van twee jaar, het traject van een ernstig bijtincident 
aangehouden moet worden. Het gedrag van de hond moet bijgestuurd worden en de eigenaar moet zich meer bewust worden van de achtergrond van het gedrag.

Bij een ernstig incident is de 'bijtrem' van de hond sterk verminderd of afwezig, waardoor de ernst van de verwonding bij het slachtoffer groter is. Hierbij kan bijvoorbeeld sprake zijn van prooiagressie indien het slachtoffer een (landbouw)huisdier betreft. Dit gedrag levert een groter direct gevaar op en adressering van dit gedragsprobleem is urgenter dan bij een licht incident. Een (kort)aanlijn- en muilkorfgebod neemt in de publieke ruimte het directe gevaar voor de omgeving weg. Daarnaast moet de eigenaar/houder veiligheidsmaatregelen nemen in de woning en om het erf om te voorkomen dat het dier zonder toezicht naar buiten kan of het erf kan verlaten. Bij dit traject wordt de optie van een heroverweging na 1 jaar gegeven om een aantal redenen. De bijtende hond kan een jonger dier zijn (jonger dan 2 jaar) dat nog niet helemaal uitontwikkeld is. Door deskundige en intensieve training kan het ongewenste gedrag weggenomen worden, waardoor ook het gevaar voor de omgeving verdwijnt. Bij volwassen dieren is het gedrag mogelijk hardnekkiger, desalniettemin is het in voorkomende gevallen mogelijk om ook het risico bij deze dieren weg te nemen. De eigenaar heeft echter een resultaatverplichting; heroverweging vindt uitsluitend plaats indien aangetoond kan worden dat eigenaar en hond met succes een erkende gedragstraining hebben gevolgd. Een gedragstest moet vervolgens uitwijzen of het risico voor de omgeving inderdaad is weggenomen.

Bij een zeer ernstig incident is sprake van het toebrengen van een zeer ernstige verwonding (gekenmerkt door weefselverlies en/of langdurig of permanent functieverlies) toegebracht aan een mens, of van de dood van een mens als direct gevolg van het incident. Het gevaar van een dergelijke hond voor de omgeving is dermate groot dat inbeslagname noodzakelijk is. Middels een risico assessment op de Faculteit Diergeneeskunde moet aangetoond worden of de hond nog terug kan keren in de maatschappij. Dit kan zijn naar de huidige eigenaar (onder voorwaarden) dan wel naar een nieuwe eigenaar. Als uit de test blijkt dat sprake is van niet te corrigeren gevaarlijke gedragskenmerken, waardoor het risico op herhaling bestaat, is euthanasie de aangewezen optie. Er moeten eisen gesteld worden aan de opslagomstandigheden om te voorkomen dat een dier (mentaal) beschadigd raakt, waardoor de kans op terugkeer in de samenleving door de periode in opslag verkleind wordt. De hond moet gelegenheid gegeven worden om te herstellen van de stress die door de veranderde omstandigheden optreedt, hetgeen vaak een aantal dagen tot een week duurt, maar de periode tussen in opslag gaan en uitvoeren van het risico assessment moet niet te lang zijn. Advies is om deze na 1 tot 2 weken uit te voeren.

In dit protocol worden de maatregelen beschreven aangaande de bijtende hond en eigenaar/houder. Maatregelen ten aanzien van het slachtoffer zijn hierin niet opgenomen. Het is echter belangrijk om te realiseren dat er ook indien er geen sprake is van een (ernstige) verwonding de mentale impact van het incident op het slachtoffer groot kan zijn. Psychische (na)zorg dient daarom te worden overwogen.

\subsection{Repressieve maatregelen}

\subsubsection{Melding, aangifte en registratie}

Inwoners van de gemeente Amsterdam kunnen bij de politie melding/aangifte doen van een bijtincident. In het verslag van het incident worden de gebeurtenissen chronologisch beschreven, allereerst vanuit het gezichtspunt van de melder (veelal slachtoffer of eigenaar van het dier dat slachtoffer is). Deze beschrijving wordt (voor zover mogelijk) aangevuld met de bevindingen van de eigenaar/houder van de bijtende hond en eventuele getuigen. Getuigen worden enkel gehoord indien dit naar het oordeel van de politie noodzakelijk is, bijvoorbeeld vanwege tegenstrijdige verklaringen met betrekking tot de toedracht door melder en eigenaar/houder. De eigenaar/houder en getuigen worden gehoord door de wijkagent.

Bij de melding/aangifte worden, zo mogelijk, de volgende gegevens opgenomen:

personalia en adresgegevens van de melder;

personalia en adresgegevens van de eigenaar/houder van de bijtende hond;

personalia en adresgegevens van eventuele getuigen;

plaats, postcode en tijdstip van het incident;

gegevens van de bijtende hond, inclusief ras/rastype (kruising), geslacht (geneutraliseerd of niet), kleur, gewicht, schofthoogte, chipnummer, roepnaam, kopie van paspoort en/of stamboomgegevens, foto, gezondheidstoestand (m.n. aanwezigheid pijn veroorzakende aandoeningen);

52 | Wageningen Livestock Research Rapport 1024 
- $\quad$ indien van toepassing gegevens gebeten hond, inclusief vermelding van ras/rastype (kruising), geslacht (geneutraliseerd of niet), chipnummer, roepnaam, kopie van paspoort en/of stamboomgegevens, foto;

indien van toepassing gegevens gebeten persoon (personalia en adresgegevens, sekse, leeftijd) of dier (anders dan hond);

beschrijving van het letsel, inclusief:

- locatie van de beet / beten,

- aanwezigheid van kneuzingen / bloedingen / blauwe plekken / wonden / botbreuken / verscheuring van weefsel / weefselverlies,

- noodzaak tot medische behandeling;

- beschrijving van de omstandigheden en aanleiding van het bijtincident, inclusief:

$\circ$ of de hond aangelijnd was (bijtende en evt. gebeten hond),

of de hond onder toezicht stond (bijtende en evt. gebeten hond, leeftijd persoon opnemen en of deze persoon de eigenaar van de hond is),

- de gebeurtenissen voorafgaand aan het incident,

- aanwezigheid van een interactie tussen bijtende en gebeten mens/dier voorafgaand aan het incident (gedrag slachtoffer voorafgaand aan incident),

- de activiteit waar het slachtoffer mee bezig was,

- het gedrag eigenaar rondom incident,

- de locatie van het incident: in de openbare ruimte (nadere aanduiding als winkelcentrum, losloopgebied) of op privé terrein (binnen/buiten),

- aanwezigheid van andere honden (aantal);

of er andere of oude meldingen zijn (tot twee jaar terug) over de desbetreffende bijtende hond;

bekendheid van de hond voor het slachtoffer (eigenaar, familielid, anders)

beschrijving bijtgedrag:

- aanwezigheid voorafgaand dreigen,

- snelheid en impact (doorbijten) van aanval,

- herhaald bijten (van één of meerdere personen),

- schudden of scheuren

Indien mogelijk worden bij de verslagen foto's van de honden en van het letsel toegevoegd. Als sprake is van een huisartsen-/ziekenhuisbezoek of dierenartsbezoek, dan wordt toestemming gevraagd aan de persoon of eigenaar om hiervan gegevens (facturen, verklaring, foto's e.d.) bij de verslagen te voegen. Indien de melder niet weet wie de eigenaar / houder van de bijtende hond is, onderzoekt de wijkagent of hij achter de naam van de eigenaar / houder kan komen.

Documentatie die later beschikbaar komt (denk aan gegevens met betrekking tot medische behandeling) wordt na het verkrijgen van toestemming zo snel mogelijk aan het dossier toegevoegd. Indien de eigenaar / houder van de bijtende hond niet te vinden is, wordt de melder hiervan in kennis gesteld en wordt aangegeven dat de melding wordt opgenomen in het gemeentelijk bestand met betrekking tot bijtincidenten. Mocht bij een volgend bijtincident in die buurt diezelfde hond betrokken zijn, dan kan de melding alsnog worden meegenomen indien met zekerheid is vastgesteld dat het om diezelfde hond gaat.

De melding wordt vanuit de politie aan een vast contactpersoon bij de gemeente doorgegeven.

\subsubsection{Beoordeling bijtincident}

Nadat de gegevens zijn verzameld wordt het incident beoordeeld en gekwalificeerd. Er wordt een onderscheid gemaakt op basis van de ernst van de gevolgen van een bijtincident. Afhankelijk van de kwalificatie licht, ernstig dan wel zeer ernstig bijtincident wordt er verschillend opgetreden.

\subsubsection{Licht bijtincident}

Er wordt van een licht (bijt)incident gesproken wanneer een hond:

1. hinderlijk of agressief gedrag vertoont zonder daadwerkelijk te bijten;

2. een ander dier of persoon bijt, waarbij er sprake is van gering letsel (bv. kneuzing, hooguit bijtpuntjes in de huid) en/of kortdurende pijn, en niet direct (dier)geneeskundige behandeling noodzakelijk is.

Wanneer bij de melding blijkt dat een hond meerdere lichte bijtincidenten heeft veroorzaakt binnen een periode van twee jaar, worden de maatregelen toegepast behorend bij een ernstig bijtincident. 


\subsubsection{Ernstig bijtincident}

Er wordt van een ernstig bijtincident gesproken wanneer een hond:

1. een persoon of een (landbouw)huisdier bijt of aanvalt, waarbij er sprake is van meer dan gering letsel (aanhoudende pijn, bloedingen, wonden, ontstekingen) en (dier)geneeskundige behandeling nodig is;

2. een persoon of (landbouw)huisdier bijt en er sprake is van (prooi)schudden en/of het niet willen loslaten, ook niet bij dwang;

3. een persoon of een (landbouw)huisdier bijt of aanvalt, waarbij er sprake is van meerdere bijtwonden met meer dan gering letsel;

4. een (landbouw)huisdier zodanig bijt of aanvalt, dat er sprake is van zeer ernstig letsel in de vorm van weefsel- en/of functieverlies, waarbij normaal functioneren langdurig dan wel permanent gehinderd is;

5. een (landbouw)huisdier zodanig bijt of aanvalt dat deze overlijdt als direct gevolg van het bijtincident.

\subsubsection{Zeer ernstig bijtincident}

Er wordt van een zeer ernstig bijtincident gesproken wanneer een hond:

1. een persoon zodanig bijt of aanvalt, dat er sprake is van zeer ernstig letsel in de vorm van weefsel- en/of functieverlies, waarbij normaal functioneren langdurig dan wel permanent gehinderd is;

2. een persoon zodanig bijt of aanvalt dat deze overlijdt als direct gevolg van het bijtincident.

\subsubsection{Maatregelen naar aanleiding van een bijtincident}

\subsubsection{Licht bijtincident}

Indien er sprake is van een (eerste) licht bijtincident wordt door de gemeente (gemandateerd aan de politie) een waarschuwingsbrief verzonden naar de eigenaar/houder/verzorger van de bijtende hond waarin wordt aangegeven dat de gemeente de hond hinderlijk acht en een waarschuwing voor de hond oplegt aan de eigenaar of houder van de hond. In de waarschuwingsbrief wordt aangegeven dat de gemeente het vanuit het oogpunt van openbare orde en veiligheid onacceptabel vindt dat een mens of (landbouw)huisdier gebeten wordt. Voorts wordt van de eigenaar/houder/verzorger verwacht dat hij maatregelen zal treffen om herhaling van een dergelijk incident te voorkomen. Dit kan bijvoorbeeld door uit voorzorg de hond aan te lijnen en te muilkorven in openbaar gebied en door rondom de woning, tuin of erf veiligheidsmaatregelen te treffen die voorkomen dat de hond zonder begeleiding de woning, tuin of erf kan verlaten. De melder van het incident krijgt een afschrift van deze brief.

Bij een tweede melding van een licht bijtincident binnen twee jaar na het voorgaande bijtincident wordt de opvolging van het incident als bij een ernstig bijtincident.

\subsubsection{Ernstig bijtincident}

Indien er sprake is van een ernstig bijtincident is het uitgangspunt dat de gemeente besluit tot gevaarlijkverklaring van de hond. De consequentie hiervan is het opleggen van een kort aanlijn- en muilkorfgebod welke beide ook gelden voor de losloopgebieden in de gemeente.

De eigenaar/houder/verzorger ontvangt een voorgenomen besluit tot gevaarlijkverklaring waarin de aanleiding wordt beschreven en de voorgenomen maatregelen zijn opgenomen. Binnen één week kan door de eigenaar/houder/verzorger een zienswijze naar voren worden gebracht. Vervolgens wordt een besluit genomen en indien de gevaarlijkverklaring wordt gehandhaafd, dient vanaf dat moment de hond in de openbare ruimte kort aangelijnd te zijn en een muilkorf te dragen. De hond mag woning, tuin of erf niet verlaten zonder kort aangelijnd en gemuilkorfd te zijn. Aanvullend dient de eigenaar/houder/verzorger daarom veiligheidsmaatregelen te treffen in de woning, tuin of erf. Deze maatregelen zijn er op gericht om te voorkomen dat de hond zonder begeleiding de woning of de tuin kan verlaten. Naleving van de oplegde maatregelen wordt gecontroleerd door de wijkagent.

\section{Heroverweging gevaarlijkverklaring}

Heroverweging van de gevaarlijkverklaring kan na een periode van 1 jaar door de eigenaar / houder van de hond aangevraagd worden. Om voor heroverweging in aanmerking te komen dient de eigenaar/houder/verzorger van de hond bewijs te overleggen van een erkende cursus die eigenaar/houder/verzorger en hond samen met goed gevolg hebben afgelegd. Voor de heroverweging dient de hond een gedragstest te ondergaan bij een gecertificeerde instelling. Indien geen vrees voor recidive bestaat wordt de gevaarlijkverklaring ingetrokken. Indien wel vrees voor recidive bestaat wordt de gevaarlijkverklaring verlengd. 


\subsubsection{Zeer ernstig bijtincident}

Indien sprake is van een zeer ernstig bijtincident gaat de gemeente direct over tot inbeslagname. De hond wordt in opslag geplaatst in afwachting van een gedragstest. Deze test moet plaatsvinden binnen 1 tot 2 weken na in opslag plaatsen van de hond en wordt uitgevoerd door de Faculteit Diergeneeskunde. Op basis van de rapportage van de test wordt besloten of en onder welke voorwaarden de hond terug kan naar de eigenaar, of de hond elders herplaatst moet worden of dat de hond geëuthanaseerd moet worden. De beslissing tot euthanasie wordt genomen indien bij de hond sprake is van niet te corrigeren gevaarlijke gedragskenmerken. Hiervan is sprake indien door de deskundige is vastgesteld dat het dier een gevaar voor zijn omgeving oplevert, waarbij dit gevaar bovendien niet kan worden weggenomen door training van het dier. 


\subsubsection{Schema opvolgende matregelen bijtincident}

In figuur 18 staat het schema waarmee na een melding van een bijtincident de te volgen stappen zijn weergegeven zoals hierboven beschreven.

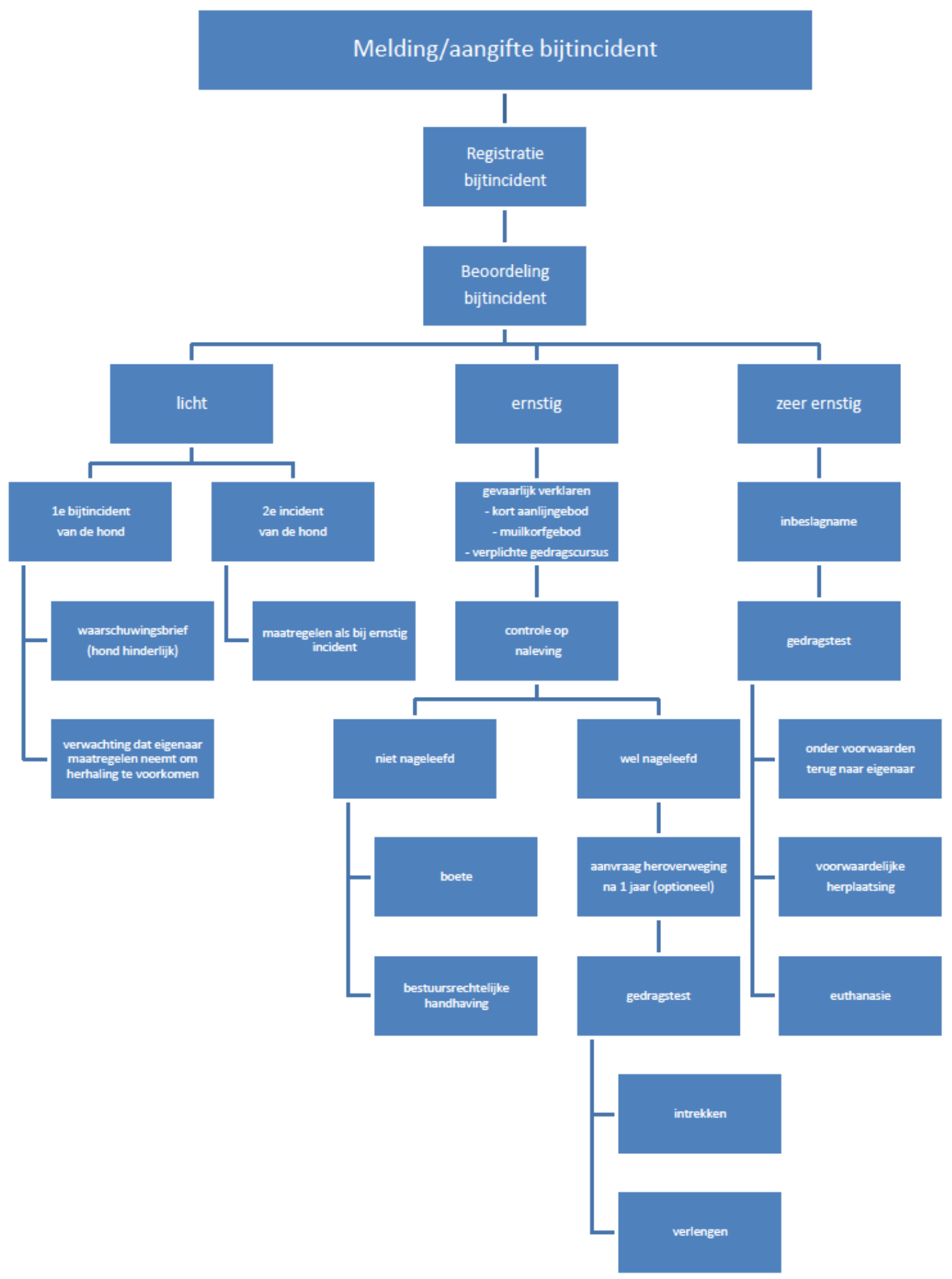

Figuur 18 Stroomschema melding bijtincident 


\subsubsection{Geraadpleegde bronnen voor het geadviseerde bijtprotocol}

- APV Amsterdam (www.regelgeving.amsterdam.nl/algemene_plaatselijke_verordening_2008).

- $\quad$ APV's diverse Nederlandse gemeenten (zoekdienst.overheid.nl/CVDR/CVDRZoeken.aspx?searchtype=Advanced, zoektermen 'gevaarlijke' en 'hond').

- Beleid bijtincidenten van verschillende Nederlandse gemeenten, waaronder:

- Beleid bijtincidenten honden 2016, Tilburg (https://tilburgers.nl/wpcontent/uploads/2016/11/02-Beleid-bijtincidenten-honden-Tilburg.pdf).

- Bijtincidenten Honden 2016, Gemeente Deurne (http://decentrale.regelgeving.overheid.nl/cvdr/images/Deurne/i276951.pdf).

- Beleidsregels bijtincidenten honden, Gemeente Súdwest-Fryslân (https://www.gemeentesudwestfryslan.nl/bestuur/beleidsstukken_44554/item/beleid sregels-bijtincidenten-honden_68185.html).

- Protocol bijtincidenten honden, Gemeente Wijdemeren (https://www.wijdemeren.nl/4/beleidsnotas/Protocol-bijtincidenten-honden.pdf).

- Besluit houders van dieren (http://wetten.overheid.nl/BWBR0035217/2017-01-01).

- Gemeentewet (http://wetten.overheid.nl/BWBR0005416/2017-01-01).

- Uitspraken rechtbank (https://uitspraken.rechtspraak.nl/\#, zoektermen 'bijtincident' en 'hond').

- Wetboek van Strafrecht (http://wetten.overheid.nl/BWBR0001854/2011-07-02/1). 


\section{Conclusies en aanbevelingen}

In het debat over hondenbeten en maatregelen die moeten voorkomen dat agressieve honden slachtoffers maken zijn grofweg twee verschillende visies te herkennen. Enerzijds wordt benadrukt dat niet alleen de hond die bijt schuldig is, laat staan dat dit geldt voor bepaalde rassen of typen. De eigenaar is verantwoordelijkheid voor de keuze van een passend type hond, aangeschaft via een professionele, bonafide fokker en voor de vereiste socialisatie, opvoeding, training en verzorging van zijn of haar hond. Anderzijds wordt betoogd dat de kans op uitsluitend verantwoordelijke eigenaren nihil is en dat honden die geselecteerd en gefokt zijn op bovenmatige agressie om die reden moeten worden verboden of in hun vrijheid dienen te worden beperkt. Daarbij wordt aangevoerd dat er een grote keuze is in rassen, dus waarom agressieve rassen niet verbieden? Dit standpunt wordt vooral via casuïstiek onderbouwd waarbij de nadruk wordt gelegd op de rol van bepaalde hondenrassen en typen die voorbeschikt lijken om eerder te bijten en daarbij ernstige bijtschade aan te brengen. Daarin gesterkt door aanwijzingen dat illegale gevechten met honden van agressieve rassen ook in ons land voorkomen. Om deze schijnbare tegenstellingen te overbruggen is het zaak om bij de mogelijke beleidsopties beide standpunten in ogenschouw te nemen.

Veiligheid voor mens en dier kent een objectieve component (de reële veiligheid) en een subjectieve (de ervaren veiligheid) component. Om met het nemen van beleidsmaatregelen de veiligheid te vergroten moeten beide elementen worden betrokken. Beide worden daarom hier besproken in het licht van aanbevolen maatregelen.

\subsection{Reële veiligheid}

Registraties van bijtincidenten zijn in het algemeen weinig nauwkeurig (bijvoorbeeld wat betreft letselbeschrijving, toedracht en duiding van ras of type agressor), over diverse systemen verspreid en niet volledig. Uit de combinatie van diverse bronnen komt het volgende beeld naar voren (zie tabel 14).

Tabel 14 Overzicht van objectieve risico's van hondenbeten naar ernst van de gevolgen.

\begin{tabular}{|c|c|c|c|c|}
\hline \multirow[b]{2}{*}{$\begin{array}{l}\text { Menselijke slachtoffers } \\
\text { van een hondenbeet }\end{array}$} & \multicolumn{3}{|c|}{ Per 100.000 inwoners } & \multirow{2}{*}{$\begin{array}{l}\text { Kans van } 1 \text { op ... } \\
\text { Nederland, } \\
\text { actuele informatie }\end{array}$} \\
\hline & $\begin{array}{l}\text { Nederland, } \\
\text { referentie } 2008\end{array}$ & $\begin{array}{l}\text { Nederland, } \\
\text { actuele informatie }\end{array}$ & $\begin{array}{l}\text { Amsterdam, } \\
\text { actuele informatie }\end{array}$ & \\
\hline Totaal aantal & 917 & $?$ & $?$ & $?$ \\
\hline $\begin{array}{l}\text { Behandeld door } \\
\text { huisarts }\end{array}$ & 324 & 460 & 300 & 217 \\
\hline Behandeld door SEH & 43 & 15,4 & $9,1^{13}$ & 6494 \\
\hline $\begin{array}{l}\text { Opgenomen in } \\
\text { ziekenhuis }\end{array}$ & 1,4 & 0,8 & $0,12^{14}$ & 125.000 \\
\hline Overleden & 0,0074 & 0,0023 & - & 43,5 miljoen \\
\hline
\end{tabular}

In Nederland komen bijtincidenten jaarlijks met een prevalentie van naar schatting 917 incidenten per 100.000 inwoners voor (Cornelissen and Hopster, 2008). Grofweg vindt twee derde van deze bijtincidenten plaats in de huiselijke omgeving waarbij vooral kinderen worden gebeten door een bekende (eigen) hond. Bij de meeste bijtincidenten wordt geen medische hulp ingeroepen. In enkele gevallen is opname in het ziekenhuis noodzakelijk; hondenbeten met dodelijke afloop blijven beperkt tot 0-1 keer per jaar (zie tabel 14). De directe jaarlijkse medische kosten als gevolg van hondenbeten bedragen voor Nederland naar schatting gemiddeld ruim 1 miljoen. Ter vergelijking, in totaal leidden sportblessures die werden behandeld op de SEH-afdeling of waarvoor een sporter werd opgenomen in het ziekenhuis in 2016 tot $€ 150$ miljoen aan medische kosten (Valkenburg and Stam, 2017).

\footnotetext{
${ }^{13}$ Schatting op basis van registraties bij VU-Ziekenhuis en AMC
} 
Tabel 15 Overzicht van overlijdensrisico's, inclusief de kans op overlijden als gevolg van een hondenbeet $^{14}$

\begin{tabular}{|l|c|}
\hline Overlijden door & $\begin{array}{c}\text { Kans van 1 op ... } \\
\text { Nederland, } \\
\text { actuele informatie }\end{array}$ \\
\hline Vallen & 4.900 \\
\hline Passief roken & 32.100 \\
\hline Fietsen & 91.900 \\
\hline Moord & 163.500 \\
\hline Griep & 170.000 \\
\hline Vliegtuigongeluk & 1,4 miljoen \\
\hline Bijensteek & 5 miljoen \\
\hline Mazelen & 43 miljoen \\
\hline Hondenbeet & 43,5 miljoen \\
\hline
\end{tabular}

Het intrekken van de Regeling Agressieve Dieren in 2009 heeft niet geleid tot een toename van de hondenbetenproblematiek; integendeel, op basis van actuele cijfers is een afname geconstateerd. Het aantal bezoeken aan de huisarts is weliswaar gestegen, maar die stijging kan niet los gezien worden van de substitutie van duurdere tweedelijnszorg door goedkopere eerstelijnszorg. Bedoeld wordt dat de patiënt een verwijzing van de huisarts nodig heeft om zich te melden voor

ziekenhuiszorg. Het aantal bezoeken aan de spoedeisende hulp, het aantal ziekenhuisopnames en het aantal incidenten met een dodelijke afloop is afgenomen. De kans op overlijden als gevolg van andere, weliswaar minder bedreigende oorzaken is vele malen kleiner (zie tabel 15). In de breedte is de problematiek dan ook in ernst afgenomen. Met deze cijfers steekt Nederland gunstig af bij andere landen. De situatie in Amsterdam lijkt in vergelijking met die in Nederland niet ongunstig, ook al zijn de gegevens over SEH-bezoeken en ziekenhuisopnames gebaseerd op registraties bij uitsluitend het AMC en het VU-ziekenhuis. In hoeverre dit ook geldt voor de aard en omvang van bijtincidenten waarbij dieren slachtoffer zijn is onbekend.

Landelijk ligt het aantal meldingen bij de politie van een 'gevaarlijke hond' rond de 3.000 per jaar, in Amsterdam rond de 200 per jaar. Deze meldingen kunnen betrekking hebben op een dreiging of op een daadwerkelijk bijtincident. Gemiddeld worden bij de politie in Amsterdam jaarlijks 158 bijtincidenten gemeld. Meer dan de helft betreft incidenten waarbij dieren werden gebeten, voornamelijk andere honden. In 57\% van de gevallen liep de hond die beet los, was deze losgebroken of ontsnapt. Bij ongeveer $10 \%$ van de incidenten kon de eigenaar niet worden achterhaald. Bij gemelde bijtincidenten, gericht op mensen, leidden deze in $69 \%$ van de gevallen tot geen of gering letsel. In $25 \%$ was het letsel matig of ernstig. Bij honden en andere dieren als slachtoffer was dit respectievelijk $49 \%$ en $38 \%$ en $15 \%$ en $72 \%$. Hoe kleiner het slachtoffer, des te ernstiger het letsel. In totaal is van $4,1 \%$ van de gemelde bijtincidenten eveneens aangifte gedaan. Hoewel ieder (ernstig) bijtincident er een teveel is, lijkt op basis van deze bevindingen voorzichtig te kunnen worden geconcludeerd dat hondenbeten voor mensen in Amsterdam reëel gezien een beperkt veiligheidsrisico vormen. Uit ons onderzoek blijkt dat bijtincidenten met honden niet beperkt zijn tot bepaalde rassen of typen, ook al zijn het PSB-cluster ${ }^{15}$ en Herderachtigen in de bij de politie in Amsterdam gemelde bijtincidenten oververtegenwoordigd. In hoeverre dit ligt aan het type hond en/of aan het type eigenaar blijft onduidelijk.

\subsection{Ervaren veiligheid}

Ondanks de beoordeling van hondenbeten als beperkt reëel veiligheidsrisico kan de veiligheid in de publieke ruimte door burgers met of zonder hond heel anders worden ervaren. Waarschijnlijk worden lang niet alle bijtincidenten of dreigende situaties bij de politie gemeld en iedereen die wel eens bij een bijtincident betrokken is geweest, weet hoe beangstigend dat is. Nog afgezien van de pijn van eventuele verwondingen. Geen wonder dat mensen dan ook proberen om onveilige situaties te vermijden. Zij voelen zich op straat bedreigd door honden, getypeerd als 'vechthonden', in het bijzonder als hun eigenaren deze gebruiken om anderen te imponeren. Omdat het niet meevalt om nuchter in te schatten wat het risico is, staat de veiligheidsbeleving van mensen soms ver af van het objectieve risico. Het beeld dat juist honden van dit type sinds het intrekken van de RAD de veiligheid van mens en dier bedreigen zien zij bevestigd in de honden die in Nederland in beslag zijn genomen en in honden die betrokken zijn bij bijtincidenten die bij de politie zijn geregistreerd. Uit ons onderzoek blijkt dat meer dan de helft van de 349 tussen 2013 en 2017 in beslag genomen honden behoort tot het type Pitbull, inclusief kruisingen. Een vergelijkbaar beeld ontstaat uit de honden die in

\footnotetext{
14 https://view.publitas.com/noordhoff-atlassen-and-additionals/bladertool-bosatlas-van-de-veiligheid/page/4-5

15 Onder het PSB-cluster zijn op basis van de beschrijvingen van de politie honden geclusterd en als volgt aangeduid: American Bulldog, American Pitbull, American Stafford, Bull terriër, Staffordshire Bull terriër, Staffordachtigen en Pitbullachtigen.
} 
Amsterdam bij de politie zijn geregistreerd. Daarvan behoort $43 \%$ tot het PSB-cluster. Het overige deel, voor zover bekend, is verdeeld over diverse rassen en typen. Bij meldingen van bijtincidenten bij de politie en bij inbeslagnames blijken honden van het type Pitbull dus onevenredig vaak als agressor betrokken te zijn. Niet uitgesloten is dat incidenten waarbij honden van dit type, ongeacht het letsel dat zij aanrichtten, vanwege hun gevaarlijke imago of vanwege de combinatie van hond en eigenaar vaker bij de politie gemeld werden. Dat niet iedere hondeneigenaar ongelukken, moedwillig of door een ongelukkige samenloop van omstandigheden, weet te voorkomen wordt bevestigd door die incidenten waarbij de bijters zijn ontsnapt of losgebroken, loslopen in de wijk en waarvan de eigenaar onvindbaar is. Ernstige bijtincidenten waarbij honden van het PSB-cluster zijn betrokken, worden in de regel breed uitgemeten in de media. Dergelijke berichtgeving appelleert aan het beeld dat burgers van dit type hond hebben en versterkt het gevoel van onveiligheid. Het aanwijzen van honden als zijnde gevaarlijk blijkt bij burgers de meldingsbereidheid van incidenten waar dergelijke honden bij betrokken zijn te vergroten. Daarbij komt, ook al is de reden niet bekend, dat bij meldingen van bijtincidenten of gevaarlijke situaties bij de politie in Amsterdam slechts in 4\% van de gevallen aangifte is opgenomen. Dit, samen met het ontbreken van een bijtprotocol, kan het gevoel van Amsterdammers versterken dat de gemeentelijke overheid en de lokale handhaving slachtoffers van bijtincidenten weinig serieus nemen.

\subsection{Aanbevolen maatregelen}

Om het aantal hondenbeten in Amsterdam te verminderen, maar vooral bij burgers het gevoel van veiligheid te verhogen bevelen wij de volgende maatregelen aan. Bestuurders raden wij aan duidelijk te maken dat het hen ernst is om deze problematiek aan te pakken. Wij adviseren daarom de gemeente om langs de onderstaande drie beleidslijnen zelf initiatief en verantwoordelijkheid te nemen voor de uitvoering van de voorgestelde maatregelen.

\subsubsection{Repressief beleid}

Repressief beleid wordt ingevuld met het onverwijld invoeren van repressieve maatregelen i.c. een bijtprotocol met een driedeling naar letselduiding en inclusief de mogelijkheid van een bestuursrechtelijk houdverbod. Hiermee geeft de gemeente aan de zorgen van burgers over gevaarlijke honden serieus te nemen. Vooral omdat dit handhavers instrumenten in handen geeft om effectiever op te kunnen treden, waarmee herhaling van (ernstige) bijtincidenten kan worden voorkomen en op de korte termijn het gevoel van veiligheid wordt versterkt. Om de melding van bijtincidenten en gevaarlijke situaties te faciliteren en de registratie te verbeteren adviseren wij om een gemeentelijk meldpunt in te richten. Daarbij past dat aan slachtoffers van gemelde bijtincidenten de nodige nazorg wordt verleend in de vorm van een brochure slachtofferhulp bij bijtincidenten. Wij adviseren de gemeente de volgende maatregelen:

1) Stel op basis van het advies bijtprotocol een definitief bijtprotocol vast en veranker dit in de APV. Een belangrijk onderdeel van het bijtprotocol is het houdverbod. Leg eigenaren van honden die in de publieke ruimte twee keer een ernstig of eenmaal een zeer ernstig bijtincident hebben veroorzaakt een houdverbod op;

2) In hoeverre rassen/typen en hun kruisingen bestempeld moeten worden als potentieel gevaarlijk wordt bepaald door de prevalentie van ernstige en zeer ernstige hondenbeten binnen de aanwezige populatie van een ras of type. Het aantal geregistreerde incidenten per ras of type ten opzichte van het aantal in Amsterdam aanwezige honden van dat ras of type geldt als basis voor een gemeentelijke lijst met potentieel gevaarlijke rassen of typen. Deze lijst wordt iedere 3 jaar opnieuw geijkt.

3) Verplicht eigenaren van potentieel gevaarlijke rassen of typen zonder 'sociale hond' certificaat tot kort aanlijnen buiten het eigen terrein en tot begeleiding van de hond op straat door personen van minimaal 18 jaar. Beboet overtredingen met forse boetes;

4) Beschrijf in de APV voor potentieel gevaarlijke rassen en typen specifieke eisen met betrekking tot een ontsnappingsveilig erf of verblijf en formuleer en implementeer extra maatregelen om de aanschaf en houderij van honden van gevaarlijke rassen of typen te ontmoedigen. 


\subsubsection{Preventief beleid}

De hondenbetenproblematiek is veel breder dan de incidenten in de publieke ruimte die gemeld worden of de media halen. Dat is het zichtbare en meest aangrijpende topje van de ijsberg. Onder de

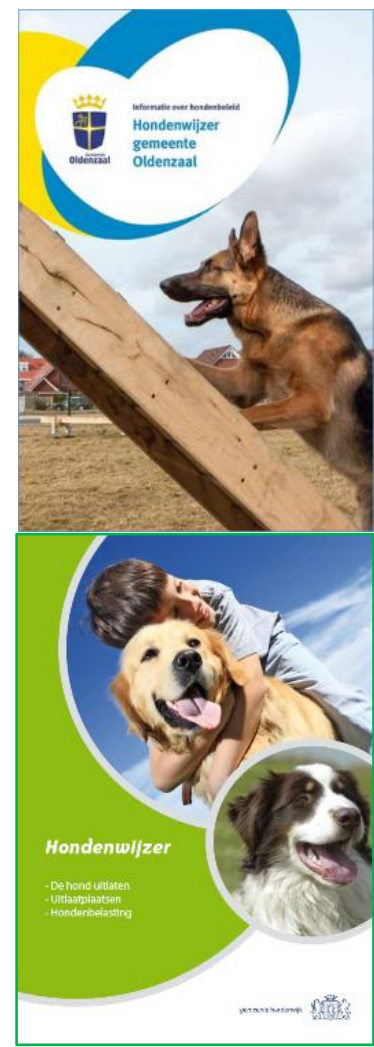
waterspiegel van handhaving en media bevindt zich een veel omvangrijker cohort van voornamelijk kinderen die meestal in de thuissituatie door een bekende (eigen) hond worden gebeten.

Dergelijke ervaringen laten sporen na, niet alleen fysiek maar ook psychisch. Uiteraard zijn ouders en verzorgers in eerste instantie verantwoordelijk voor de veiligheid van kinderen. Maar ook voor de gemeentelijke overheid zien wij een rol.

Wij adviseren om via actieve voorlichting in te zetten op bewustwording en op verantwoord houderschap. Concreet geven we de gemeente de volgende maatregelen in overweging:

1) Richt naar analogie van de jeugdgezondheidszorg een consultatiebureau in voor veterinaire basiszorg, preventie van gedragsproblemen bij honden in de leeftijd van 0-2 jaar en ondersteuning van verantwoordelijk gedrag bij de eigenaar. Uitvoering ligt bij de dierenartsenpraktijken in de gemeente. Jonge honden bezoeken met hun eigenaar op een aantal vaste momenten de consultatiedienst. Dit biedt de mogelijkheid om eventuele risico's die voortkomen uit de combinatie van eigenaar en hond tijdig te signaleren en gericht te adviseren over hoe deze terug zijn te dringen. Consulten zijn gratis en verplicht, vaccinaties, overige gezondheidszorg en eventuele gedragstherapie zijn voor kosten van de eigenaar;

2) Stimuleer alle puppyeigenaren tot het volgen van minimaal een puppycursus bij een gekwalificeerde instructeur maar stel voor honden met een volwassen gewicht van $>20 \mathrm{~kg}$ een puppy- èn een gehoorzaamheidscursus verplicht en koppel hieraan een 'sociale hond' certificaat. Honden met een certificaat zijn als zodanig op afstand herkenbaar, bijvoorbeeld aan hun hondenpenning. Kosten van de cursus zijn voor rekening van de eigenaar;

3) Vergroot het aantal uitlaatgebieden en/of richt loslooprennen in en overweeg om deze op verschillende tijden en/of per gebied open te stellen voor honden met en honden zonder 'sociale hond' certificaat. Ook valt te overwegen om gebieden apart open te stellen voor honden lichter dan wel zwaarder dan $20 \mathrm{~kg}$;

4) Versterk bewustwording van volwassenen door voorlichting over veilige omgang van het kind met de hond via specifieke kanalen als verloskundigenpraktijken, consultatiebureaus, baby- en peuteropvang en van kinderen door voorlichting op basisscholen;

5) Verstrek aan hondenbezitters een gemeentelijke brochure 'Hondenwijzer' waarin de regels voor baas en hond zijn beschreven alsmede informatie beschikbaar is over verantwoord houderschap, gekwalificeerde instructeurs, uitlaatgebieden en loslooprennen, repressieve maatregelen en de APV;

6) Burgers die een gevaarlijke/onveilige situatie (voor mens of dier) willen melden moeten dit laagdrempelig en anoniem kunnen doen, bij voorkeur in de eigen (deel)gemeente. Meldingen dienen snel en accuraat doorgegeven te worden aan de politie zodat de wijkagent contact met de eigenaar van de hond kan opnemen om gevaarlijke situaties te bespreken en erger te voorkomen. Dit geldt ook voor meldingen over loslopende (kleinere) honden die aangelijnde honden 'lastig vallen';

7) Verstrek aan slachtoffers van bijtincidenten of (bij dieren) aan hun eigenaren een folder met informatie over letselschade en shockschade die kan optreden als gevolg van ernstige verwonding van het primaire slachtoffer en over mogelijkheden om materiële en immateriële schade en proceskosten te verhalen op de eigenaar van de hond die de schade heeft aangericht. Vermeld in deze folder ook adressen waar mensen terecht kunnen voor slachtoffer- en psychologische hulp. 


\subsubsection{Registratie en evaluatie}

Tot de hierboven geadviseerde maatregelen kan de gemeente zelf besluiten. De adviezen die volgen zijn deels gericht op de Rijksoverheid. Zoals eerder aangegeven is de registratie van bijtincidenten en letselschade in het algemeen weinig nauwkeurig, onvolledig en over diverse registratiesystemen verspreid. Ook de registratie van honden in het kader van I\&R behoeft verbetering. Zonder een adequate registratie van honden en hondenbeten ontbreekt een gedetailleerd en volledig inzicht in de achterliggende oorzaken en gevolgen van bijtincidenten. Bovendien is het dan niet goed mogelijk om specifieke maatregelen te treffen die gericht de oorzaak van bijtincidenten kunnen wegnemen en om deze te evalueren op hun effectiviteit. Wij adviseren daarom om dit probleem dringend bij de Rijksoverheid op de agenda te zetten. Door de registratie op landelijk niveau goed in te richten is het mogelijk om de vinger ook op gemeentelijk niveau voldoende aan de pols te houden en te voorkomen dat repressieve maatregelen beperkt zijn tot gemeentegrenzen. Wij geven de gemeente het volgende in overweging:

1) Bepleit bij de Rijksoverheid de ontwikkeling van een geactualiseerde, gestandaardiseerde, volledige en betrouwbare landelijke registratie van honden (verplichte I\&R ook van honden die voor 1 april 2013 geboren zijn);

2) Bepleit bij de Rijksoverheid de inrichting van een geactualiseerde, gestandaardiseerde, volledige en betrouwbare landelijke registratie van bijtincidenten, gericht op mensen maar ook op honden, inclusief gegevens zoals aangegeven in paragraaf 8.3.1;

3) Breng deze registraties in lijn met de registraties bij ziekenhuizen (SEH/ziekenhuizen), huisartsen en dierenartsen (bv door Medisch Centrum voor Dieren AniCura) zodat aard en omvang van de hondenbetenproblematiek in Amsterdam op elk moment integraal kunnen worden geëvalueerd;

4) Bepleit bij de Rijksoverheid de mogelijkheid voor gemeenten om een houdverbod op te leggen;

5) Bepleit bij de Rijksoverheid dat repressieve maatregelen die door gemeenten aan eigenaren van gevaarlijke honden worden opgelegd om herhaling van bijtincidenten te voorkomen, landelijk worden geregistreerd en in het gehele land gelden;

6) Onderzoek waarom slechts $4 \%$ van de gemelde bijtincidenten heeft geresulteerd in een aangifte en handel op basis van de bevindingen zodanig dat slachtoffers van bijtincidenten zich voldoende gehoord voelen.

\subsection{Gebruik van de HR-lijst}

Op verzoek van het Ministerie van Economische Zaken is door experts een lijst opgesteld van hondenrassen en typen met een hoog risico op agressie, de zogenaamde hoog-risico (HR) lijst. In dat kader is eveneens besloten dat honden van rassen op deze lijst, maar met een stamboom erkend door de Raad van Beheer, niet vallen onder de categorie HR hond. Met de HR-lijst beoogt het Ministerie van LNV gemeenten te ondersteunen bij het aanwijzen van honden als zijnde gevaarlijk of hinderlijk.

Wij ontraden op dit moment het gebruik van een lijst van hoog-risico rassen of typen, ondanks dat uit de inbeslagnames en registraties bij de politie blijkt dat honden van het type Pitbull en kruisingen met honden van dit type oververtegenwoordigd zijn. Onze argumenten daarvoor zijn drieërlei:

I. Vergelijken we de honden van de huidige HR-lijst met de honden die in beslag zijn genomen en voorkomen in de registratie van de politie in Amsterdam, dan zien we zowel overeenkomsten als verschillen. De overeenkomst zit in de Pitbullachtigen, kruisingen en aanverwante typen en rassen. Van alle 349 in beslag genomen honden behoort bijna driekwart $(n=249 ; 71 \%)$ tot rassen/typen van de HR-lijst. De Duitse en de Mechelse Herders behoren tot de top 10 van de lijst van in beslag genomen honden, maar deze komen echter niet voor op de HR-lijst. Van de bij de politie geregistreerde bijtincidenten was bij $83 \%$ het ras of type vermeld. Bij $53 \%$ van de incidenten werd gebeten door honden van rassen of typen die vermeld staan op de HR-lijst.

Deze cijfers maken duidelijk dat een relatief groot deel van de in beslag genomen en bij de politie 
in Amsterdam geregistreerde honden, eveneens op de HR-lijst is vermeld. Ook is duidelijk dat een deel van de bijtincidenten is veroorzaakt door honden die niet op de HR-lijst staan (vals negatief). Nog afgezien van de rassen en typen die wel op de HR-lijst staan, maar niet (vals-positief) of nauwelijks in genoemde dossiers voorkomen. Bovendien vormen niet alle honden die behoren tot de op de HR-lijst genoemde rassen en typen een potentieel gevaar. Het is vooral de combinatie van het type eigenaar en het type hond dat het risico op een bijtincident bepaalt. Vanwege deze beperkte betrouwbaarheid zal het gebruik van de huidige HR-lijst naar verwachting beperkingen kennen, afhankelijk van hoe deze door de gemeente wordt gebruikt. Koppeling van generieke maatregelen zal tot veel discussie, nevenschade en maatschappelijke onrust leiden, waardoor deze maatregelen in effectiviteit tekort zullen schieten.

II. In hoeverre rassen/typen en hun kruisingen bestempeld moeten worden als potentieel gevaarlijk wordt bepaald door de prevalentie van ernstige en zeer ernstige hondenbeten binnen de aanwezige populatie van een ras of type. Het aantal geregistreerde incidenten per ras of type ten opzichte van het aantal aanwezige honden van dat ras of type zien wij als een verantwoorde basis voor een lijst met potentieel gevaarlijke rassen of typen. Op dit moment ontbreekt overtuigend bewijs dat in ons land honden van rassen en typen die genoemd zijn op de hoog-risico lijst als ze bijten per definitie ernstige bijtschade veroorzaken. Gesteld dat de registraties van honden en hondenbeten conform ons advies zijn ingericht, is het niet eerder dan over minimaal 3 jaar dat een goed onderbouwde lijst kan worden opgesteld;

III. De Regeling Agressieve Dieren die destijds als doel had om honden van het type Pitbull te laten uitsterven leidde in de rechtsgang tot aanzienlijke problemen, vooral omdat de identificatie van het betreffende type door deskundigen niet éénduidig kon worden uitgevoerd. Een problematische identificatie geldt in het bijzonder kruisingen tussen rassen en typen die ontegenzeglijk in omvang en variatie gaan toenemen indien specifieke rassen of typen generieke beperkingen krijgen opgelegd. Om handhavers evenwel in staat te stellen om risicovolle combinaties van honden en aantoonbaar onverantwoordelijke eigenaren te voorkomen, dient de gemeente tijdig een houdverbod op te kunnen leggen. Daarnaast dient de bekendheid van het (strafrechtelijk) houdverbod vergroot en de handhaafbaarheid verbeterd te worden. Dit is recent door de Minister van Veiligheid en Justitie toegezegd, inclusief de belofte dat het houdverbod als zelfstandige maatregel mogelijk zal worden gemaakt ${ }^{16}$.

\subsection{Financiering voorgestelde maatregelen}

Om het voorgestelde beleid en de maatregelen die daar uit voortvloeien te financieren geven wij de gemeente in overweging om de hondenbelasting weer in te voeren. Wij realiseren ons dat deze per 1 januari 2016 is afgeschaft, naar blijkt ${ }^{17}$ vooral omdat de opbrengsten niet werden aangewend voor het bestrijden van de hondenoverlast en/of voor het verbeteren van de voorzieningen voor honden. Bezwaarschriften kwamen vooral voort uit een niet actuele registratie van honden. Met de voorgestelde maatregelen wordt aan deze bezwaren tegemoetgekomen en komt er jaarlijks, afhankelijk van het tarief, ca. 1,5 miljoen euro beschikbaar om de maatregelen in te voeren. In Amsterdam heeft naar schatting 1 op de 20 huishoudens een hond. Met het voorgestelde beleid zal duidelijk zijn dat de bijdrage van hondeneigenaren in de vorm van belasting traceerbaar wordt besteed aan het versterken van de openbare veiligheid voor mens en dier, voor zover deze door het houden van honden wordt bedreigd. Daarnaast zijn preventieve maatregelen gericht op het vergroten van de veiligheid achter de voordeur. Niet in de laatste plaats de huishoudens waarin honden worden gehouden en de honden zelf plukken daar de vruchten van. Wij adviseren de gemeente tenslotte te (blijven) zoeken naar overlegstructuren met hondenbezitters om de participatiebereidheid met het gemeentelijk beleid van deze groep te vergroten/versterken (compliance).

\footnotetext{
${ }^{16}$ Contourenbrief Houdverbod (kenmerk: 2061131), 30 juni 2017, Ministerie van Veiligheid en Justitie, Den Haag

${ }^{17}$ Factsheet afschaffing hondenbelasting, Bestuursopdracht 7A, 21 mei 2015.
} 
Arhant, C., Bubna-Littitz, H., Bartels, A., Futschik, A. and Troxler, J. (2010) 'Behaviour of smaller and larger dogs: Effects of training methods, inconsistency of owner behaviour and level of engagement in activities with the dog', Applied Animal Behaviour Science, 123, pp. 131-142. doi: 10.1016/j.applanim.2010.01.003.

Arhant, C., Landenberger, R., Beetz, A. and Troxler, J. (2016) 'Attitudes of caregivers to supervision of child-family dog interactions in children up to 6 years-An exploratory study', Journal of Veterinary Behavior: Clinical Applications and Research, 14, pp. 10-16. doi: 10.1016/j.jveb.2016.06.007.

Arluke, A., Cleary, D., Patronek, G. and Bradley, J. (2017) 'Defaming Rover: Error-Based Latent Rhetoric in the Medical Literature on Dog Bites', Journal of Applied Animal Welfare Science. Routledge, pp. 1-13. doi: $10.1080 / 10888705.2017 .1387550$.

AVSAB (2014) 'Position Statement on Breed-Specific Legislation | ASPCA', p. 4. Available at: http://www.aspca.org/about-us/aspca-policy-and-position-statements/position-statement-breedspecific-legislation (Accessed: 25 November 2016).

Bálint, A., Faragó, T., Dóka, A., Miklósi, Á. and Pongrácz, P. (2013) '"Beware, I am big and nondangerous!" - Playfully growling dogs are perceived larger than their actual size by their canine audience', Applied Animal Behaviour Science, 148(1-2), pp. 128-137. doi: 10.1016/j.applanim.2013.07.013.

Bandow, J. H. (1996) 'Will breed-specific legislation reduce dog bites?', Canadian Veterinary Journal, 37, pp. 478-481.

Barnes, J. E., Boat, B. W., Putnam, F. W., Dates, H. F. and Mahlman, A. R. (2006) 'Ownership of High-risk ("vicious") dogs as a marker for deviant behaviors', Journal of Interpersonal Violence, 21(12), pp. $1616-1623$.

Basu, I., Ryba, F. and Osher, J. (2016) 'Dog Bites Resulting in Facial Injuries in Children - A 5 year Retrospective Study at King's College Hospital', British Journal of Oral and Maxillofacial Surgery, 54(10), p. e152. doi: 10.1016/j.bjoms.2016.11.242.

Beata, C., Sarcey, G., Ricard, C. and Thelot, B. (2017) Descriptive study of dog bites in France Severity factors. Factors of onset of sequelae. Circumstances. Results of a survey conducted by InVS and Zoopsy in 2009-2010, Journal of Veterinary Behavior: Clinical Applications and Research. Elsevier Inc. doi: $10.1016 / j$.jveb.2017.07.006.

van den Berg, L. (2016) 'Genetics of dog behavior', in Serpell, J. A. (ed.) The domestic dog: its evolution, behaviour, and interactions with people. Second edi. Cambridge: Cambridge University Press, pp. 6992.

Van den Berg, L., Schilder, M. B., De Vries, H., Leegwater, P. A. and Van Oost, B. A. (2006) 'Phenotyping of aggressive behavior in golden retriever dogs with a questionnaire.', Behavior genetics. doi: 10.1007/s10519-006-9089-0.

Bini, J. K., Cohn, S. M., Acosta, S. M., McFarland, M. J., Muir, M. T. and Michalek, J. E. (2011) 'Mortality, Mauling, and Maiming by Vicious Dogs', Annals of Surgery, 253(4), pp. 791-797. doi: $10.1097 /$ SLA.0b013e318211cd68.

Blackshaw, J. K. (1991) 'An overview of types of aggressive behaviour in dogs and methods of treatment', Applied Animal Behaviour Science, 30, pp. 351-361.

Blackwell, E. J., Twells, C., Seawright, A. and Casey, R. A. (2008) 'The relationship between training methods and the occurrence of behavior problems, as reported by owners, in a population of domestic dogs', Journal of Veterinary Behavior: Clinical Applications and Research, 3, pp. 207-217. doi: 10.1016/j.jveb.2007.10.008.

Blouin, D. D. (2013) 'Are dogs children, companions, or just animals? understanding variations in people's orientations toward animals', Anthrozoos, 26(2), pp. 279-294. doi: $10.2752 / 175303713 \times 13636846944402$.

Borchelt, P. L. (1983) 'Aggressive behavior of dogs kept as companion animals: classification and influence of sex, reproductive status and breed', Applied Animal Ethology. Elsevier Scientific Publishing Company, 10 , pp. 45-61.

van der Borg, J. A. M., Graat, E. A. M. and Beerda, B. (2017) 'Behavioural testing based breeding policy reduces the prevalence of fear and aggression related behaviour in Rottweilers', Applied Animal Behaviour Science, (Accepted Manuscript). doi: 10.1016/j.applanim.2017.06.004.

Bradley, J. (2014) Dog bites: problems and solutions (revised 2014). POLICY PAPER A contemporary perspective on incidence, risk factors and effective prevention. Animals and Society Institute.

Bradshaw, J. and Rooney, N. (2016) 'Dog social behavior and communication', in Serpell, J. A. (ed.) The domestic dog: its evolution, behaviour, and interactions with people. Second edi. Cambridge: Cambridge University Press, p. 147-.

Butcher, R. (2006) 'Preventing dog bites', BMJ, 159, p. 500. doi: 10.1136/vr.159.15.500-b.

Casey, R. A., Loftus, B., Bolster, C., Richards, G. J. and Blackwell, E. J. (2013) 'Inter-dog aggression in a UK owner survey: prevalence, co-occurrence in different contexts and risk factors.', The Veterinary record, 172(5), p. 127. doi: 10.1136/vr.100997.

CBS Statline (2016) 'Tabel: Bevolking; ontwikkeling in gemeenten met 100000 of meer inwoners: Amsterdam'. Available at: http://statline.cbs.nl/Statweb/publication/?DM =SLNL\&PA=70748ned\&D1=0,39,83\&D2=0\&D3=0\&D4=5 $\& D 5=0,(1-2)-1 \& V W=T$.

CBS Statline (2017) Tabel: Overledenen; doodsoorzaak (uitgebreide lijst) 1996-2016. Available at: http://statline.cbs.nl/Statweb/publication/?DM =SLNL\&PA=7233\&D1=1557\&D2=0\&D3=0\&D4=a\&HDR= G2,G1,G3\&STB=T\&VW=T (Accessed: 11 November 2017).

Clarke, N. M. and Fraser, D. (2013) 'Animal control measures and their relationship to the reported

64 | Wageningen Livestock Research Rapport 1024 
incidence of dog bites in urban Canadian municipalities', Canadian Veterinary Journal, 54(2), pp. 145149.

Collier, S. (2006) 'Breed-specific legislation and the pit bull terrier: Are the laws justified?', Journal of Veterinary Behavior: Clinical Applications and Research, 1, pp. 17-22. doi: 10.1016/j.jveb.2006.04.011.

Commissie van Wijzen (2008) 'Hondenbeten in perspectief. Een evaluatie van de RAD en aanbevelingen voor het terugdringen van bijtincidenten.', Een evaluatie van de RAD en aanbevelingen voor het .... Available at: http://www.stray-afp.org/nl/wp-content/uploads/2012/08/Hondenbeten-in-perspectiefCommissie-van-Wijzen-8-mei-2008.pdf.

Cornelissen, J. and Hopster, H. (2008) Bijlage feiten en cijfers, Animal Sciences Group van Wageningen UR, Lelystad. Opgenomen in: Hondenbeten in perspectief, Commissie van Wijzen, Den Haag, 2008.

Cornelissen, J. M. R. and Hopster, H. (2010) 'Dog bites in The Netherlands: A study of victims, injuries, circumstances and aggressors to support evaluation of breed specific legislation', Veterinary Journal. Elsevier Ltd, 186(3), pp. 292-298. doi: 10.1016/j.tvjl.2009.10.001.

Craig, L., Meyers-Manor, J. E., Anders, K., Sütterlin, S. and Miller, H. (2017) 'The relationship between heart rate variability and canine aggression', Applied Animal Behaviour Science. doi: 10.1016/j.applanim.2016.12.015.

Creedon, N. and Ó Súilleabháin, P. (2017) 'Dog bite injuries to humans and the use of breed-specific legislation: A comparison of bites from legislated and', Irish Veterinary Journal, 70(23), p. 9 p.

D'Onise, K., Hazel, S. and Caraguel, C. (2017) 'Mandatory desexing of dogs: one step in the right direction to reduce the risk of dog bite? A systematic review', Injury Prevention. Available at: http://injuryprevention.bmj.com/content/early/2017/01/27/injuryprev-2016-042141.abstract.

Dibevo en NVG (2017) Meer dan 4 miljoen huishoudens hebben één of meer huisdieren. Available at: https://www.dibevo.nl/pers/meer-dan-4-miljoen-huishoudens-hebben-een-of-meer-huisdieren (Accessed: 6 March 2017).

Duffy, D. L., Hsu, Y. and Serpell, J. A. (2008) 'Breed differences in canine aggression', Applied Animal Behaviour Science, 114, pp. 441-460. doi: 10.1016/j.applanim.2008.04.006.

Duijnker, A. (2016) De Hond Statussymbool of Bitcoin? Scriptie, School voor Hogere Politiekunde van de Politieacademie, kernopgave 9303033. 144p.

Dunbar, I. (no date) 'Dr Ian Dunbar's Dog Bite Scale'. Available at: http://www.dogtalk.com/BiteAssessmentScalesDunbarDTMRoss.pdf (Accessed: 27 June 2017).

Ellis, J. L., Thomason, J. J., Kebreab, E. and France, J. (2008) 'Calibration of estimated biting forces in domestic canids: Comparison of post-mortem and in vivo measurements', Journal of Anatomy, 212(6), pp. 769-780. doi: 10.1111/j.1469-7580.2008.00911.x.

Ellis, J. L., Thomason, J., Kebreab, E., Zubair, K. and France, J. (2009) 'Cranial dimensions and forces of biting in the domestic dog', Journal of Anatomy, 214(3), pp. 362-373. doi: $10.1111 / \mathrm{j} .1469-$ 7580.2008.01042.x.

Farhoody, P. and Zink, C. (2010) 'Behavioral and physical effects of spaying and neutering domestic dogs (Canis familiaris)'.

Gazzano, A., Lauria, C., Ducci, M. and Sighieri, C. (2015) 'Dog attention and cooperation with the owner: preliminary results about brachycephalic dogs', Dog Behavior. doi: 10.4454/DOGB.V1I1.001.

Gemeente Amsterdam (2008a) Amsterdam in cijfers 2008.

Gemeente Amsterdam (2008b) De Amsterdamse hondenindex, www.ois.amsterdam.nl/nieuws/deamsterdamse-hondenindex. Available at: http://www.ois.amsterdam.nl/nieuws/de-amsterdamsehondenindex.

Gemeente Amsterdam (2016a) Agenda Dieren 2015-2018. Een diervriendelijk Amsterdam. Available at: https://www.amsterdam.nl/toerisme-vrije-tijd/dieren/agenda-dieren-2015/.

Gemeente Amsterdam (2016b) 'Vaststellen van de Begroting 2016 Gemeente Amsterdam (2015, nr. 238/1144)'. Available at: https://zoek.officielebekendmakingen.nl/gmb-2015-116868.html.

Gilchrist, J., Sacks, J. J., White, D. and Kresnow, M.-J. (2008) 'Dog bites: still a problem?', Injury Prevention, 14(5), pp. 296-301. doi: 10.1136/ip.2007.016220.

Greaves, W. S. (1985) 'The generalized carnivore jaw', Zoological Journal of the Linnean Society, 85(3), pp. 267-274. doi: 10.1111/j.1096-3642.1985.tb01506.x.

Greven, J. and Bosveld, W. (2014) 'Hondenbezit in Amsterdam'. O\&S.

Hallsworth, S. (2011) 'Then they came for the dogs!', Crime, Law and Social Change, 55(5), pp. 391-403. doi: http://dx.doi.org/10.1007/s10611-011-9293-6.

Harding, S. (2014) Unleashed: The Phenomena of Status Dogs and Weapon Dogs. Policy Press.

Heinze, S., Feddersen-Petersen, D. U., Tsokos, M., Buschmann, C. and Püschel, K. (2014) 'Tödliche Attacken von Hunden auf Kinder: Aktualgenese und Motivation bei spezifischer Kasuistik und bestimmten pathomorphologischen Veränderungen', Rechtsmedizin, 24(1), pp. 37-41. doi: 10.1007/s00194-013-0932-3.

Het Parool (no date) 'Bijtprotocol is juist gevaarlijk voor honden' - Opinie. Available at: http://www.parool.nl/opinie/-bijtprotocol-is-juist-gevaarlijk-voor-honden a4221969/.

Hoff, G. L., Cai, J., Kendrick, R. and Archer, R. (2005) 'Emergency department visits and hospitalizations resulting from dog bites, Kansas City, Mo, 1982-2002.', Missouri Medicine, 102, pp. 565-568. Available at: http://europepmc.org/abstract/MED/16355644.

Hondenbescherming (ed.) (2016) 'Politie Haaglanden cijfers bijtincidenten', in seminar Problematiek met hoog risico honden. Zeist.

Honey, L. (2017) 'Do dogs bite without warning, or should we see it coming?', Veterinary Record, 180(2), pp. 35-36. doi: 10.1136/vr.i6767.

Horisberger, U., Stärk, K. D. C., Rüfenacht, J., Pillonel, C. and Steiger, A. (2004) 'The epidemiology of dog bite injuries in Switzerland - characteristics of victims, biting dogs and circumstances', Anthrozoos, 17(4), pp. 320-339. Available at: http://www.tandfonline.com.ezproxy.library.wur.nl/doi/pdf/10.2752/089279304785643212?needAcces $\mathrm{s}=$ true (Accessed: 11 April 2017).

ION (2015) JAARVERSLAG STICHTING INSCHRIJVING OP NAAM Een. Available at: https://ion.Ihv.nl/sites/default/files/content/ion_lhv_nl/uploads/content/jaarverslag_2015_stichting_ins chrijving_op_naam_-_website_0.pdf. 
Jakovcevic, A., Elgier, A. M., Mustaca, A. E. and Bentosela, M. (2010) 'Breed differences in dogs' (Canis familiaris) gaze to the human face', Behavioural Processes, 84, pp. 602-607. doi: 10.1016/j.beproc.2010.04.003.

Kaspersson, M. (2008) 'On Treating the Symptoms and not the Cause: Reflections on the Dangerous Dogs

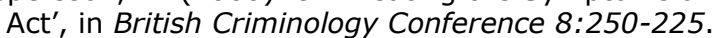

Kaufmann, C. A., Forndran, S., Stauber, C., Woerner, K. and Gansloßer, U. (2017) 'The Social Behaviour of Neutered Male Dogs Compared to Intact Dogs (Canis Lupus Familiaris): Video Analyses, Questionnaires and Case Studies', Veterinary Medicine - Open Journal, 2(1), pp. 22-37. doi: 10.17140/VMOJ-2-113.

de Keuster, T. and Butcher, R. (2008) 'Preventing dog bites: Risk factors in different cultural settings', The Veterinary Journal, 177, pp. 155-156. doi: 10.1016/j.tvjl.2007.11.006.

Klaassen, B., Buckley, J. R. and Esmail, A. (1996) 'Does the Dangerous Dogs Act protect against animal attacks: a prospective study of mammalian bites in the Accident and Emergency department', Injury, 27(2), pp. 89-91. doi: 10.1016/0020-1383(96)83411-5.

Kovács, K., Kis, A., Pogány, Á., Koller, D. and Topál, J. (2016) 'Differential effects of oxytocin on social sensitivity in two distinct breeds of dogs (Canis familiaris)' ${ }^{\prime}$ Psychoneuroendocrinology, 74, pp. 212220. doi: 10.1016/j.psyneuen.2016.09.010.

Kubinyi, E., Turcsán, B. and Miklósi, Á. (2009) 'Dog and owner demographic characteristics and dog personality trait associations', Behavioural Processes, 81(3), pp. 392-401. doi: 10.1016/j.beproc.2009.04.004.

Lafarge, M. (2016) Contribution à l'étude du comportement de prédation du chien sur l'homme. Médecine vétérinaire.

Langley, R. L. (2009) 'Human fatalities resulting from dog attacks in the United States, 1979-2005.', Wilderness \& environmental medicine. Elsevier, 20(1), pp. 19-25. doi: 10.1580/08-WEME-OR-213.1.

Ledger, R. a, Orihel, J. S., Clarke, N., Murphy, S. and Sedlbauer, M. (2005) 'Breed specific legislation: Considerations for evaluating its effectiveness and recommandations for alternatives', The Canadian veterinary journal, 46, pp. 735-743.

Leiden, I. van, Hardeman, M., Ham, T. Van, Scholten, L. and Wijk, A. van (2016) Hoe lopen de hazen? De stand van zaken in de aanpak van dierenmishandeling en dierenverwaarlozing.

Lockwood, R. (2016) 'Ethology, ecology and epidemiology of canine aggression', in Serpell, J. A. (ed.) The Domestic Dog: Its Evolution, Behavior and Interactions with People. Second edi. Cambridge: Cambridge University Press, pp. 160-181. doi: 10.1017/9781139161800.

Lord, K., Schneider, R. A. and Coppinger, R. (2016) 'Evolution of working dogs', in Serpell, J. (ed.) The domestic dog: its evolution, behaviour, and interactions with people. Second edi. Cambridge: Cambridge University Press, pp. 42-67. doi: 10.1017/9781139161800.004.

Maharaj, N. and Haney, C. J. (2015) 'A qualitative investigation of the significance of companion dogs.' Western Journal of Nursing Research, 37(9), pp. 1175-1193. doi: 10.1177/0193945914545176.

Maksymowicz, K., Janeczek, A., Szotek, S., Łukomski, R. and Dawidowicz, J. (2016) 'Dog bites in humans in a large urban agglomeration in the southwest of Poland, an analysis of forensic medical records', Journal of Veterinary Behavior: Clinical Applications and Research, 12, pp. 20-26. doi: 10.1016/j.jveb.2015.12.007.

Martínez, Á. G., Santamarina Pernas, G., Diéguez Casalta, F. J., Suárez Rey, M. L., De La Cruz Palomino, L. F., González Martínez, N., Pernas, G. S., Javier, F., Casalta, D., Luisa, M., Rey, S. and De La Cruz Palomino, L. F. (2011) 'Risk factors associated with behavioral problems in dogs', Journal of Veterinary Behavior: Clinical Applications and Research, 6(4), pp. 225-231. doi: 10.1016/j.jveb.2011.01.006.

McGreevy, P. D., Georgevsky, D., Carrasco, J., Valenzuela, M., Duffy, D. L. and Serpell, J. A. (2013) 'Dog Behavior Co-Varies with Height, Bodyweight and Skull Shape', PLOS ONE. Edited by A. J. Munn, 8(12), p. e80529. doi: 10.1371/journal.pone.0080529.

McMillan, F. D. (2017) 'Behavioral and psychological outcomes for dogs sold as puppies through pet stores and/or born in commercial breeding establishments: Current knowledge and putative causes', Journal of Veterinary Behavior: Clinical Applications and Research. Best Friends Animal Society, Kanab, Utah, United States, 19, pp. 14-26. doi: 10.1016/j.jveb.2017.01.001.

Meershoek, P. (2016) 'Amsterdam werkt aan nieuw bijtprotocol na snelle toename gevaarlijke honden Amsterdam - PAROOL', Het Parool. Available at: http://www.parool.nl/amsterdam/amsterdam-werktaan-nieuw-bijtprotocol-na-snelle-toename-gevaarlijke-honden a4217143/.

Mehrkam, L. R. and Wynne, C. D. L. (2014) 'Behavioral differences among breeds of domestic dogs (Canis lupus familiaris): Current status of the science', Applied Animal Behaviour Science, 155, pp. 12-27. doi: 10.1016/j.applanim.2014.03.005.

Messam, LIm. L. L. M., Kass, P. H. P., Chomel, B. B. B. and Hart, L. A. La (2013) 'Age-related changes in the propensity of dogs to bite', The Veterinary Journal, 197(2), pp. 378-387. doi: 10.1016/j.tvjl.2013.01.024.

Meyer, I. and Forkman, B. (2014a) 'Dog and owner characteristics affecting the dog-owner relationship', Journal of Veterinary Behavior: Clinical Applications and Research, 9(4), pp. 143-150. doi: 10.1016/j.jveb.2014.03.002.

Meyer, I. and Forkman, B. (2014b) 'Nonverbal Communication and Human-Dog Interaction', Anthrozoös, 27(4), pp. 553-568. doi: 10.2752/089279314X14072268687925 .

Miklósi, Á., Turcsán, B. and Kubinyi, E. (2014) The Personality of Dogs, The Social Dog: Behavior and Cognition. doi: 10.1016/B978-0-12-407818-5.00007-3.

Mills, D., van der Zee, E. and Zulch, H. (2014) When the Bond Goes Wrong: Problem Behaviours in the Social Context, The Social Dog. Elsevier. doi: 10.1016/B978-0-12-407818-5.00008-5.

Mittmann, A. (2002) Untersuchung des Verhaltens von 5 Hunderassen und einem Hundetypus im Wesenstest nach den Richtlinien der Niedersächsischen Gefahrtierverordnung vom 05.07.2000. Tierärztlichen Hochschule in Hannover.

Mullins, J. and Harrahill, M. (2008) 'Dog Bites: A Brief Case Review', Journal of Emergency Nursing, 34(5), pp. 490-491. doi: 10.1016/j.jen.2008.06.009.

O'Brien, D. C., Andre, T. B., Robinson, A. D., Squires, L. D. and Tollefson, T. T. (2015) 'Dog bites of the head and neck: an evaluation of a common pediatric trauma and associated treatment', American Journal of Otolaryngology, 36(1), pp. 32-38. doi: 10.1016/j.amjoto.2014.09.001.

Ó Súilleabháin, P. (2015) 'Human hospitalisations due to dog bites in Ireland (1998-2013): Implications for

66 | Wageningen Livestock Research Rapport 1024 
current breed specific legislation', The Veterinary Journal, 204(3), pp. 357-359. doi:

10.1016/j.tvjl.2015.04.021.

Ó Súilleabháin, P. and Doherty, N. (2015) 'Epidemiology of dog bite injuries: Dog-breed identification and dog-owner interaction', Journal of Plastic, Reconstructive \& Aesthetic Surgery, 68(8), pp. 1157-1158. doi: $10.1016 / j . b j p s .2015 .03 .025$.

onbekend (2015) 'Bestuursopdracht 7a. Factsheet afschaffing hondenbelasting', pp. 1-5.

Ott, S. A. S. A., Schalke, E., von Gaertner, A. M. A. M. and Hackbarth, H. (2008) 'Is there a difference? Comparison of golden retrievers and dogs affected by breed-specific legislation regarding aggressive behavior', Journal of Veterinary Behavior: Clinical Applications and Research, 3(3), pp. 134-140. doi: 10.1016/j.jveb.2007.09.009.

Ott, S. A., Schalke, E., von Gaertner, A. M. and Hackbarth, H. (2008) 'Is there a difference? Comparison of golden retrievers and dogs affected by breed-specific legislation regarding aggressive behavior', Journal of Veterinary Behavior: Clinical Applications and Research, 3(3), pp. 134-140. doi: 10.1016/j.jveb.2007.09.009.

Overall, K. L. (2010) 'Breed specific legislation: How data can spare breeds and reduce dog bites', Veterinary Journal, 186(3), pp. 277-279. doi: 10.1016/j.tvjl.2010.04.023.

Overall, K. L. and Love, M. (2001) 'Dog bites to humans-demography, epidemiology, injury, and risk', JAVMA, 218(12).

Oxley, J. A., Christley, R. and Westgarth, C. (2017) 'Contexts and consequences of dog bite incidents', Journal of Veterinary Behavior: Clinical Applications and Research. Elsevier Inc. doi: 10.1016/j.jveb.2017.10.005.

Ozanne-Smith, J., Ashby, K. and Stathakis, V. Z. (2001) 'Dog bite and injury prevention-analysis, critical review, and research agenda', Injury Prevention, 7, pp. 321-326. Available at: http://injuryprevention.bmj.com/content/injuryprev/7/4/321.full.pdf (Accessed: 24 March 2017).

Raad van Beheer (2014) Houden van honden.

Raad voor Dierenaangelegenheden (2013) Verantwoord Honden Houden.

Raad voor Dierenaangelegenheden (2017) Hondenbeten aan de Kaak gesteld. Available at: http://rda.nl/home/files/2017/RDA.2017.031 Zienswijze Hondenbeten aan de Kaak gesteld, Preventie van Ernstige Hondenbeten bij Mens en Dier (DEF VERSIE 23.02.2017).pdf.

Raghavan, M., Martens, P. J. J., Chateau, D. and Burchill, C. (2013) 'Effectiveness of breed-specific legislation in decreasing the incidence of dog-bite injury hospitalisations in people in the Canadian province of Manitoba', Injury Prevention, 19(3), pp. 177-183. doi: 10.1136/injuryprev-2012-040389.

Řezáč, P., Viziová, P., Dobešová, M., Havlíček, Z. and Pospíšilová, D. (2011) 'Factors affecting dog-dog interactions on walks with their owners', Applied Animal Behaviour Science, 134(3-4), pp. 170-176. doi: 10.1016/j.applanim.2011.08.006.

Rosado, B., García-Belenguer, S., Leó N, M., Palacio, J., León, M. and Palacio, J. (1995) 'A comprehensive study of dog bites in Spain, 1995-2004', The Veterinary Journal, 179(3), pp. 383-391. doi: 10.1016/j.tvjl.2008.02.002.

Rosado, B., García-Belenguer, S., León, M. and Palacio, J. (2007) 'Spanish dangerous animals act: Effect on the epidemiology of dog bites', Journal of Veterinary Behavior: Clinical Applications and Research, 2(5), pp. 166-174. doi: 10.1016/j.jveb.2007.07.010.

Sacks, J. J., Kresnow, M. and Houston, B. (1996) 'Dog bites: how big a problem?', Injury prevention : journal of the International Society for Child and Adolescent Injury Prevention, 2(1), pp. 52-54. doi: 10.1136/IP.2.1.52.

Sacks, J. J., Sinclair, L., Gilchrist, J., Golab, G. C. and Lockwood, R. (2000) 'Breeds of dogs involved in fatal human attacks in the United States between 1979 and 1998.' , Journal of the American Veterinary Medical Association, 217(6), pp. 836-840. doi: 10.2460/javma.2000.217.836.

Schalke, E., Ott, S. A., von Gaertner, A. M., Hackbarth, H. and Mittmann, A. (2008) 'Is breed-specific legislation justified? Study of the results of the temperament test of Lower Saxony', Journal of Veterinary Behavior: Clinical Applications and Research, 3(3), pp. 97-103. doi: 10.1016/j.jveb.2007.10.004.

Schenk, A. M., Ragatz, L. L. and Fremouw, W. J. (2012) 'Vicious Dogs Part 2: Criminal Thinking, Callousness, and Personality Styles of Their Owners', Journal of Forensic Sciences, 57(1), pp. 152-159. doi: $10.1111 /$ j.1556-4029.2011.01961.x.

Schilder, M. B. H., Van Eijken, I. A. M. and Vinke, C. M. (2012) «Grrr...hap! Soms doen veel verhalen den ronde over de. Bijtincidenten door honden, Gedragskliniek info. Available at: http://docplayer.nl/15015332-Grrr-hap-soms-doen-veel-verhalen-den-ronde-over-de-bijtincidentendoor-honden.html.

Serpell, J. A. (2016) 'From paragon to pariah: Cross-cultural perspectives on attitudes to dogs', in Serpell, J. (ed.) The domestic dog: its evolution, behaviour, and interactions with people. Second edi. Cambridge: Cambridge University Press, pp. 300-316. doi: 10.1017/9781139161800.015.

Serpell, J. A. and Hsu, Y. (2005) 'Effects of breed, sex, and neuter status on trainability in dogs', Anthrozoos, 18(3), pp. 196-207. doi: 10.2752/089279305785594135.

Shepherd, K. (2002) 'Development of behaviour: social behaviour and communication in dogs', in Horwitz, D.F., Mills, D., Heath, S. (ed.) BSAVA Manual of Canine and Feline Behavioural Medicine.

Song, S., Scheu, A., Gopalan, S., Pendleton, A. L., Botigue, L. R., Zeeb-lanz, A., Arbogast, R., Oetjens, M., Taravella, A. M., Serege, T., Burger, J., Kidd, J. M., Veeramah, K. R., Bobo, D., Daly, K. and Unterla, M. (2017) 'Ancient European dog genomes reveal continuity since the Early Neolithic', Nature Communications, 8(16082), pp. 1-11. doi: 10.1038/ncomms 16082 .

Svartberg, K. (2006) 'Breed-typical behaviour in dogs-Historical remnants or recent constructs?', Applied Animal Behaviour Science, 96, pp. 293-313. doi: 10.1016/j.applanim.2005.06.014.

Svartberg, K. and Forkman, B. (2002) 'Personality traits in the domestic dog (Canis familiaris)', Applied Animal Behaviour Science, 79(2), pp. 133-155. doi: 10.1016/S0168-1591(02)00121-1.

Svartberg, K., Tapper, I., Temrin, H., Radesäter, T. and Thorman, S. (2005) 'Consistency of personality traits in dogs', Animal Behaviour, 69(2), pp. 283-291. doi: 10.1016/j.anbehav.2004.04.011.

Tami, G. and Gallagher, A. (2009) 'Description of the behaviour of domestic dog (Canis familiaris) by experienced and inexperienced people', Applied Animal Behavior Science, 120, pp. 159-169. doi: 10.1016/j.applanim.2009.06.009. 
Turcsán, B., Range, F., Virányi, Z., Miklósi, Á. and Kubinyi, E. (2012) 'Birds of a feather flock together? Perceived personality matching in owner-dog dyads', Applied Animal Behaviour Science, 140(3-4), pp. 154-160. doi: 10.1016/j.applanim.2012.06.004.

Valkenburg, H. and Stam, C. (2017) Sportblessures 2016: SEH bezoeken. Amsterdam. Available at: https://www.kenniscentrumsport.nl/publicatie/?sportblessures-2016\&kb_id=22995.

VeiligheidNL (2017) Bijtincidenten 2010-2015 Letsel cijfers.

Villalbi, J. R. R., Cleries, M., Bouis, S., Peracho, V., Duran, J., Casas, C., Boui, S., Peracho, V., Duran, J., Casas, C., Villalbí, J. R., Cleries, M., Bouis, S., Peracho, V., Duran, J. and Casas, C. (2010) 'Decline in hospitalisations due to dog bite injuries in Catalonia, 1997-2008. An effect of government regulation?', Injury Prevention, 16(6), pp. 408-410. doi: 10.1136/ip.2010.026997.

Voith, V. L. (2009) 'The Impact of Companion Animal Problems on Society and the Role of Veterinarians', Veterinary Clinics of North America: Small Animal Practice, 39(2), pp. 327-345. doi: 10.1016/j.cvsm.2008.10.014.

Vonholdt, B. M. and Driscoll, C. A. (2016) 'Origins of the dog: Genetic insights into dog domestication', in Serpell, J. (ed.) The Domestic Dog. Cambridge: Cambridge University Press, pp. 22-41. doi: 10.1017/9781139161800.003.

Walsh, F. (2017) 'Human-Animal Bonds II : The Role of Pets in Family Systems and Family Therapy Human-Animal Bonds II : The Role of Pets in Family', 48(December 2009), pp. 481-500. doi: 10.1111/j.1545-5300.2009.01297.x.

Wells, D. L. and Hepper, P. G. (2012) 'The personality of "aggressive" and "non-aggressive" dog owners', Personality and Individual Differences. doi: 10.1016/j.paid.2012.05.038.

Wilsson, E. (2016) 'Nature and nurture?How different conditions affect the behavior of dogs', Journal of Veterinary Behavior: Clinical Applications and Research, 16, pp. 45-52. doi: 10.1016/j.jveb.2016.10.002.

Wright, J. C. (1996) 'Canine aggression: dog bites to people', Readings in companion animal behavior. Trenton, NJ:, pp. 17-19. Available at:

http://www.mercer.edu/psychology/Faculty_Staff/Wright_JC/downloadable_articles/Canine Aggression - Dog Bites to People.pdf.

Zawistowski, S. and Reid, P. (2016) 'Dogs in today's society: The role of applied animal behavior', in Serpell, J. A. (ed.) The domestic dog: its evolution, behaviour, and interactions with people. Second edi. Cambridge: Cambridge University Press, pp. 227-244. 


\section{Bijlage 1 Expert interviews}

Binnen het project is een aantal experts uit verschillende organisaties geïnterviewd, om de verschillende aspecten die van belang zijn bij de opzet van een bijtprotocol te bespreken. Gesprekken zijn gevoerd met de volgende experts:

$>$ Hondenbrigade Amsterdam

$>$ Dierenopvang Amsterdam

$>$ Werkgroep Hulp Inbeslaggenomen Honden

$>$ Dierenbescherming

$>$ Hondenbescherming

$>$ Wageningen University \& Research
Jolanda Dijkstra, Hennie Buis, Rob Lichters

Hans Fokkens

Sandra van de Werd

Elly von Jessen

Ineke van Herwijnen, Just de Wit

Joanne van den Borg

\section{Incidentie}

- De perceptie over verandering in de incidentie van bijtincidenten is wisselend. Een afname wordt niet ervaren, maar of er sprake is van een gelijkblijvende incidentie dan wel een toename varieert in de belevingen.

- Op meerdere fronten komen er meer signalen van incidenten binnen, waarbij de hond-mens incidenten niet toegenomen lijken, maar wel de problematiek met 'moeilijke' honden, de ernst van de verwondingen en de hond-hond incidenten.

\section{Afschaffen RAD}

- Over het effect van het afschaffen van de RAD wisselen de meningen. Doordat cijfers ontbreken is het niet mogelijk aan te geven of er een toename in het aantal incidenten is geweest. Het afschaffen heeft er wel toe geleid dat de mogelijkheden om in te grijpen beperkter zijn.

- $\quad$ De RAD had als effect dat eigenaren voor honden met een stamboom kozen. Een hond kreeg alleen een stamboom als de ouderdieren met succes de MAG test hadden doorlopen, wat aangeeft dat er een acceptabel (laag) agressie niveau aanwezig is. Dit zorgde voor een stukje drempelvorming en sturing op een verantwoordelijke fokker.

- $\quad \mathrm{Na}$ afschaffen kwamen er opeens explosief veel volwassen honden tevoorschijn, wat impliceert dat deze al wel aanwezig waren alleen niet zichtbaar.

\section{Gemeentelijke vs. landelijke aanpak}

- Een landelijke aanpak zou heel goed zijn, bij voorkeur formuleren van houderijvoorschriften, om het welzijn van honden te verbeteren.

- Het voordeel van een landelijk (geldend) systeem is dat daarmee voorkomen wordt dat mensen naar andere gemeentes gaan in geval van opgelegde maatregelen.

- Voordeel juist voor gemeentelijk systeem is bv. dat bij een gemeente waar de problematiek nauwelijks speelt ook weinig kosten hoeven te maken.

- Soms kan landelijke regelgeving een gemeente helpen, kijk bv. naar de aanbeveling van RDA, landelijk geld voor aanlijn/muilkorfplicht. Steun bieden voor handhaving en veiligheid.

- Een eenduidig beleid voor de aanpak van bijtincidenten is noodzakelijk. Een APV-maatregel geldt alleen voor 1 gemeente, wat de kans op shoppen en misbruik door eigenaren geeft. Eenduidigheid is zeker van belang in geval van een muilkorfgebod. Gemeentegrenzen lopen door een bos heen, tijdens wandelen kan een eigenaar in principe de muilkorf afgooien. Hier lijkt ook misbruik van gemaakt te worden. Generiek beleid geeft duidelijkheid naar burgers en houders. Overal moeten dezelfde regels gelden, dit is niet alleen voor burgers van belang maar ook voor professionals.

- Voor wat betreft een database voor registratie van incidenten is er een voorkeur voor een landelijk systeem. Uit een dergelijk registratiesysteem kunnen tendensen waargenomen worden, waarop beleid gemaakt of bijgesteld kan worden. Een landelijke database moet meer zicht geven op waar de risico's zitten, feedback en betrouwbare cijfers, onderbouwing van de effectiviteit van maatregelen. Dit moet gefaciliteerd worden door de overheid, die moet het eigenaarschap op zich nemen.

\section{Cijfers en registratie}

- $\quad$ Een goede registratie begint met $I \& R$, verplichte registratie bij de aanschaf van een hond. 
- Het nut van een betrouwbare registratie wordt door alle experts onderschreven. Nu is de manier, volledigheid en betrouwbaarheid van registratie zeer variabel wat de mogelijkheid tot een analyse verhindert. Dit kan leiden tot vooringenomenheid zonder een echte onderbouwing. Doelstelling van een betrouwbaar registratiesysteem is waarheidsvinding, handelingsperspectief en beleidsevaluatie.

- De voorkeur gaat uit naar een landelijke database, om een eenduidige manier van registreren te bewerkstelligen. Er zijn per gemeente vaak weinig gevallen, waardoor ook de analysemogelijkheden beperkt zijn. Alternatief is een gemeentelijk systeem, waarbij het echter essentieel is dat gegevens gedeeld worden. Hierbij moeten afspraken gemaakt worden over wat er vastgelegd moet worden om de opvolging van incidenten en evaluatie van het beleid mogelijk te maken. incidenten door kleine honden worden mogelijk minder vaak gemeld, wat een vertekening van het beeld kan geven.

- Incidenten die in ieder geval geregistreerd moeten worden zijn hond-mens en hond-hond incidenten. Incidenten met andere diersoorten zijn beperkter van nut, gezien het prooigedrag dat in veel rassen aanwezig is.

- $\quad$ Een laagdrempelig meldingssysteem moet ervoor zorgen dat incidenten makkelijk gemeld kunnen worden. Het moet mogelijk zijn om incidenten of een gevoel van onveiligheid anoniem te melden, met name als sprake is van een criminele eigenaar. Misbruik van registratie moet voorkomen worden. Registratie moet bij voorkeur plaatsvinden bij de politie en eventueel de ziekenhuizen. Registratie door dierenartsen en huisartsen zou ertoe kunnen leiden dat slachtoffers geen medische hulp zoeken (bv. bij een incident in het eigen gezin door de eigen hond).

- $\quad$ Een landelijke registratie van opgelegde maatregelen moet voorkomen dat eigenaren gaan shoppen, door bij een opgelegd aanlijn- en muilkorfgebod de hond in een andere gemeente uit te laten.

- Voor het vaststellen van de ernst van het incident c.q. de verwonding moet een objectief en uniform beoordelingsprotocol gebruikt worden.

- Vastleggen van de context van het incident is noodzakelijk, deze kan aanleiding geven tot verandering. Bij het nastreven van volledigheid van alle relevante informatie rondom een incident moet echter de invulbaarheid en uitvoerbaarheid niet uit het oog verloren worden.

\section{Lijst HR-honden}

- Bijtproblematiek geldt voor de hele hondenpopulatie in NL, maar accent komt steeds meer te liggen op honden die ernstige bijtincidenten veroorzaken. Een aantal rassen is langdurig geselecteerd op bepaalde eigenschappen. Of binnen zo'n ras een betreffende hond ook daadwerkelijk een hoog risico vormt wordt bepaald door de erfelijke eigenschappen, de benutting van de gevoelige periode en de kwaliteit van het houderschap

- Verhoogd aantal incidenten in een ras betekent niet dat alle individuen van dat ras gevaarlijk zijn.

- Als een groep honden aangewezen wordt als HR-honden, is het aan te raden de ouderdieren op sociaal goed gedrag te testen voordat ermee gefokt gaat worden. De vraag is hoe er omgegaan moet worden met kruisingen van die rassen.

- Er zijn verschillende vormen van bijtgedrag: angst, agressie of prooi. Specifiek fokken en/of trainen op het willen bijten is ongewenst. Er zijn zeker lijnen waarin de agressie veel hoger is dan in andere lijnen. Dit is niet alleen ras (of type) gebonden. Bij de opvoeding van energieke, dominante honden uit deze lijnen is een straffe hand, met name in de puberteit (1-1.5 jaar), noodzakelijk.

- De HR-lijst met honden holt achter de feiten aan. Veel wenselijker is om een positieve aanpak te hanteren waarbij gewenste rassen en kruisingen gestimuleerd worden.

\section{Educatie en preventie}

\section{Educatie:}

- Gemeenten moeten een rol nemen in het voorlichting geven.

- Omgaan met honden opnemen in het onderwijs, zowel de omgang in de openbare ruimte als ook de omgang met honden binnenshuis

- Gedragsregels voor eigenaren en niet-eigenaren in lokale media onder de aandacht brengen

- Potentiele eigenaren (en liefhebbers) moeten goed voorgelicht worden door de verkoper, er moet duidelijk zijn wat het dier gaat vragen en de potentiele eigenaar moet een goede inschatting van zichzelf hebben

- Verloskundigenpraktijken moeten informatie over huisdieren en de omgang hiermee (ook door kinderen). Bij huisartsen en consultatiebureaus moet voorlichtingsmateriaal beschikbaar zijn 


\section{Preventie:}

- Een beleidsrichtlijn/protocol gemeente zou daar gerichter wat voor kunnen doen: gedragstherapeut instellen, een stappenplan binnen APV, aanlijnen, muilkorven, educatieve maatregelen

- $\quad$ Principe zou algemeen hondenbeleid moeten zijn, bv.

- alle honden een muilkorf in de openbare ruimte, tenzij de eigenaar aantoonbaar de hond aankan

- verantwoord houderschap onder voorwaarde zodat houders een pasje kunnen laten zien Dit geeft handvatten aan handhaving en voorkomt dat HR-honden gedefinieerd moeten worden

- Deelname aan cursussen stimuleren en veldjes faciliteren

- Creëren van voldoende en ruime losloopgebieden, evt. seizoen afhankelijk helemaal of gedeeltelijk openstellen of speciale losloopgebieden voor HR-honden

- $\quad$ Fokkers moeten traceerbaar zijn

- Eigenaar moeten voor het gebruik van losloopgebieden over een pasje beschikken, die verkregen kan worden door aantoonbaar goed eigenaarschap

- De muilkorf zou een positieve uitstraling moeten krijgen

- Meldingen van onveilige situaties of een onveilig gevoel moeten mogelijk gemaakt of zelfs gestimuleerd worden, bestempelen als gevaarlijke hond nadat het al mis gegaan is is te laat (vaak zijn er al signalen dat er wat gaande is). De gemeente zou periodiek onderzoek moeten doen naar het gevoel van veiligheid in de wijk

- Sociale hulppartners zouden aan elkaar verbonden moeten zijn, omdat zij achter de voordeur komen, en juist honden in die situaties vaker betrokken zijn verwaarlozing en huiselijk geweld

- Indien daartoe aanleiding is moet een houdverbod opgelegd en gehandhaafd kunnen worden

- Een houder moet voor de aanschaf van een hond al een cursus volgen

- Bewustwording van de eigenschappen van met name een HR-hond moet er toe leiden dat aanschaf (deels) ontmoedigd wordt

- Verplicht 'rijbewijs' voor de (toekomstige) houders van HI honden.

- Ondersteuning van DOA (bv in de contacten met hondeneigenaren) of: DOA geeft aan politie door waar een HR hond wordt geplaatst.

- Dierenartsen moeten signaleren dat een hond mogelijk agressie gaat vertonen en eigenaren attent maken op gedragstherapeuten.

- Er zou een ontmoediging moeten plaatsvinden door bij problemen een muilkorf en castratie te verplichten.

- In Fairfok staat niks over het gedrag.

\section{Houder, hond, context}

- $\quad$ De relatieve bijdrage van de 3 factoren kan sterk wisselen per incident, waarbij sprake kan zijn van een ongelukkige samenloop van omstandigheden. Ondanks de context is het wel altijd de hond die de basis is, de eigenaar/houder van de hond is echter de spil als het gaat om preventie. Al bij de aanschaf moet er nadrukkelijk aandacht besteed worden aan de combinatie eigenaarhond. Hier ligt een duidelijke rol voor de fokker en/of herplaatsende instantie. Een niet goed benutte gevoelige periode door fokker en/of eigenaar kan leiden tot meer angst en agressie, maar ook tot meer prooigedrag.

- In principe kan elke hond bijten, de ideale sociale hond bestaat niet. Het verantwoordelijkheidsgevoel van de eigenaar bepaalt echter hoe groot het risico op een incident of op recidive is. Veel incidenten zijn een eerste ervaring van de eigenaar met de minder goede kanten van de hond. Zeker indien een eigenaar zich vooraf niet verdiept heeft in de eigenschappen van het ras (een onverantwoorde aanschaf) kan de verrassing groot zijn. Bepaalde typen honden vereisen meer kennis en daadkracht (goed leiderschap) van de eigenaar dan andere. Bij een match tussen hond en eigenaar is de kans dat het mis gaat vele malen kleiner.

- Veel incidenten spelen zich binnenshuis af (naar schatting meer dan 60\%). Oorzakelijk is er een verschil tussen incidenten binnen- en buitenshuis; binnen is er vaak sprake van het overschrijden van de grenzen van de hond (waarbij kinderen vaak een rol spelen en slachtoffer zijn), buiten kan het gaan om honden die niet goed gesocialiseerd zijn en die een hekel hebben aan andere honden of bang zijn voor kinderen. Er kan sprake zijn van defensieve agressie, prooigerichte agressie of soortgerichte agressie. $\mathrm{Er}$ is een groot verschil tussen hond-hond en hond-mens agressie.

- $\quad$ Bij HR-honden gaat het om verschillende typen eigenaren die niet over een kam te scheren zijn. Bij een deel gaat het om onbenul, onwetendheid en onkunde, maar de groep die de meeste problemen oplevert is er een die zich niet laat voorlichten. 


\section{Bijtgedrag}

- $\quad$ Prooigedrag of predatie agressie is bij terriërs niet anders dan bij vechthonden, het staat (deels) ook los van het sociale gedrag van de hond. Opvoeding en onder appel staan spelen niet altijd meer als er een prooi in zicht is. Bij onvoldoende beweging en veel in huis houden zoekt zo'n hond een uitlaatklep. De eigenschap kan tijdens socialisatie goed gestuurd worden, maar kan mogelijk het hele leven gestimuleerd worden. Als het gedrag beloond wordt, wordt het in stand gehouden.

- $\quad$ Predatieagressie speelt buiten, honden zien een mens als een prooi omdat ze zoveel binnen gehouden worden. Als ze buiten iets zien bewegen, wordt dat als een prooi gezien.

- Door een hoge drift kunnen waarschuwingssignalen (agressieladder) afwezig zijn, er wordt meteen gebeten. Dit betekent niet dat het altijd gevaarlijke honden zijn, maar in bepaalde situaties wel. Dit is door training of socialisatie niet weg te krijgen.

- Vechthonden slaan alle waarschuwingssignalen over, herkennen het gedrag van de andere hond niet meer, kijken en beslissen onafhankelijk van de ander. Op de Amerikaanse pitbullterriër is jarenlang selectiedruk op gepleegd om daadwerkelijk andere honden te bijten en schade toe te brengen. De kans dat zo'n type hond dat nog steeds doet is erg groot. De erfelijke basis eruit halen is lastig, dat kan alleen door professionals in te zetten die zijn opgeleid alsook ervaring hebben met dit type honden, gedrag en signalen kunnen herkennen en het type agressie kunnen duiden.

- Het risico moet ingecalculeerd worden, maar is niet te voorkomen. Alleen bij hele goed interventies op hondenscholen is het risico te verkleinen. De kennis en kunde daar zijn echter te variabel, er worden veel eigen methodieken op na gehouden.

- Honden die getraind zijn op en gebruikt worden in gevechten kiezen specifiek voor een hond. Het is niet mogelijk om met training dit gedrag nog weg te nemen.

- $\quad$ De kennis bij gedragstherapeuten en dierenartsen over de kracht van de erfelijkheid bij agressie naar andere honden is te beperkt. Een dergelijke hond kan nooit losgelaten worden, omdat het gedrag er niet uitgehaald kan worden.

- Bijtgedrag richting mensen kan uit trauma (mishandeling) voortkomen. Bij angst en de onmogelijkheid om te vluchten blijft alleen de aanval over.

- Aanlijnen zou kunnen leiden tot meer incidenten, omdat de honden hun energie niet kwijt kunnen.

\section{Bijtprotocol (opvolging bij incident)}

- De experts verschillen van mening over de opvolging bij een (ernstig) bijtincident. Een hond is niet gebaat bij opslag, dit wordt bestempeld als lijden, maar de maatschappij moet beschermd worden tegen herhaling. Waar een expert een verblijf in een pleeggezin met stringente regels verkiest, geeft een ander aan de risico's hiervan te groot te vinden. Er moet meer gekeken worden naar de combinatie eigenaar-hond, waarbij de hond een nieuwe kans moet krijgen na heropvoeding en een goede match met de nieuwe eigenaar.

- Een 'one-strike-out' beleid zal gedeeltelijk een preventief effect hebben, doordat het de potentiele eigenaren beter laat nadenken over de aanschaf van een HR hond. Op mensen die een dergelijke hond om o.a. imago redenen aanschaffen, zullen echter niet geremd om nieuwe aanschaf te doen. Er moet in die gevallen eerder een houdverbod afgegeven worden, met name als er sprake is van ophitsing of mensen die hun hond meerdere honden hebben laten bijten.

- De meeste incidenten zijn niet zo ernstig, bij het bepalen van de opvolging moet de context nadrukkelijk meegenomen worden. Het moet duidelijk zijn waarom de hond in de fout gegaan is. Prooi gerichte agressie komt meer buiten als de hond ontsnapt en loskomt vanuit opgesloten situatie en op prooigedrag overgaat.

- $\quad$ Euthanasie alleen bij heel erg gevaarlijke honden.

- Er moet onderscheid gemaakt worden tussen lichte en ernstige incidenten.

- Lichte incidenten gebeuren vaker binnenshuis (waarschuwing naar kinderen, etc.), er kan sprake zijn van prooiagressie. Hierbij komt het aan op verantwoordelijk eigenaarschap, waarbij een cursus aangewezen is. Als het incident veroorzaakt is door een HR-hond moet een gecertificeerde gedragstherapeut een inschatting van het risico maken.

- Bij een ernstig incident is er sprak van weefselverlies, functieverlies en/of de dood van een mens of hond. De hond moet hierbij direct van de straat gehaald worden omdat het risico te groot is, maar ook om een statement naar het slachtoffer te maken. Het gaat hierbij om buitenproportionele (impulsieve) agressie. Het testen van de hond is hierbij overbodig, omdat deze al heeft laten zien dat hij dit gedrag kan vertonen.

- De bouw/grootte van de hond heeft invloed op de ernst van de aangerichte schade: een grote hond richt meer schade aan dan een kleine. 


\section{Gedragstest, gedragstherapeuten}

- $\quad$ Bij het testen van een hond moet er rekening mee gehouden worden dat niet alleen de hond belangrijk is, maar ook de eigenaar. De reactie van de eigenaar op het gedrag van de hond moet meegenomen worden in de beoordeling. De interactie is belangrijk, hieruit blijkt of de eigenaar verantwoordelijkheid neemt.

- $\quad$ Een hond zou in geval van inbeslagname direct en in aanwezigheid van de eigenaar getest moeten worden.

- $\quad$ Een hond moet gedegen getest worden om goed te kunnen inschatten wat het risico is op herhaling. De test is bedoeld om te kijken wat het risico voor de maatschappij is, en is niet voor de hond zelf. De hond moet bij de test over de grens heen gehaald worden om goed in te kunnen schatten wat het risico op herhaling is en in welke situaties zich dat voordoet.

- $\quad$ Bij voorkeur moet de hond (ook) in een praktijksituatie getest worden. Zwakke punten moeten in de praktijk gesignaleerd en geadresseerd worden, de trainbaarheid van de hond moet beoordeeld worden.

- Gedragstesten moeten wetenschappelijk onderbouwd zijn, er moet een certificering komen om de ruimte voor eigen interpretatie te verkleinen.

- $\quad$ Er zijn (te) veel verschillende stromingen in gedragsdeskundigen.

- Om meer zicht te krijgen over de invloed van de eigenaar op het gedrag van de hond, zou onderzoek uitgevoerd kunnen worden waarbij de uitkomsten van een karaktertest bij de pup vergeleken wordt met een gedragstest bij de tweejarige hond. 


\section{Bijlage 2 Geraadpleegde registratiesystemen}

Vanuit verschillende registratiesystemen is getracht een beeld te vormen van de aard en omvang van bijtincidenten:

1. Melding bij de politie van bijtincident (BlueSPoT monitor, code E82 'Gevaarlijke hond')

2. Behandeling van letsel bij een mens na een bijtincident

a. behandeling bij de huisarts na bijtincident (HIS systeem, ICPC code S13 'Beet mens/dier')

b. behandeling bij de huisartsenpost (eerstelijns spoedhulp, HIS systeem, ICPC code S13 'Beet mens/dier')

c. behandeling bij de eerste hulp door bijtincident (LIS systeem, code S13 'Beet mens/dier') (VeiligheidNL, 2017)

d. opname in ziekenhuis door bijtincident (LIS systeem, code S13 'Beet mens/dier' ) (VeiligheidNL, 2017)

3. Het aantal mensen dat overlijdt door een beet van een hond gerapporteerd in de doodsoorzakenstatistiek van het CBS (ICD code W54; Strikt genomen zouden hier ook gevallen in kunnen voorkomen die niet gebeten zijn, maar door een hond bestormd zijn, en dan ongelukkig terecht gekomen zijn bij een val o.i.d.).

4. Behandeling van letsel bij een dier na een bijtincident

a. behandeling bij een eerste lijns dierenarts na bijtincident (geen specifieke codering / landelijk systeem)

b. behandeling bij specialist dierenarts

5. In beslaggenomen honden na een bijtincident (via RVO.nl)

\section{Meldingen 'gevaarlijke hond' bij de politie}

De politie verwerkt de meldingen over een 'gevaarlijke hond' in het registratiesysteem BlueSpot Monitor onder de code E82. Een melding kan zowel gaan over een hond die als dreigend ervaren wordt als over een hond die een daadwerkelijk bijtincident veroorzaakt waarbij een mens en/of dier het slachtoffer is.

De meldingen van 144 komen niet in het datasysteem van de politie terecht. Verdere kanttekening bij interpretatie deze data is dat het niet honderd procent dekkend is wegens mutatiefouten en kan het voorkomen dat een 'gevaarlijke hond' situatie onder een andere code (meestal E83) is geregistreerd en hiermee gemist is (persoonlijke mededeling hondengeleiders politie Amsterdam).

In BlueSpot Monitor zou informatie over de dader (de hond) moeten worden opgenomen onder het tabblad 'goederen'. Dieren zijn geen zaken (zie art. 3: 2a BW) maar mogen in juridische zin wel worden gezien als waren zij zaken. De eigenaar is verantwoordelijk voor het dier en aansprakelijk voor de schade die door het dier wordt veroorzaakt (art. 6:179 BW). Niet altijd is de dader hond beschreven onder het tabblad goederen ingevuld.

\section{Huisartsen en huisartsenposten}

Hondenbeten waarvoor medische hulp gezocht wordt bij huisartsen en huisartsenposten, worden geregistreerd in het Huisarts Informatie Systeem (HIS) onder de ICPC codering (International Classification of Primary Care) S13. ICPC S13 staat voor 'beet mens/dier'. Deze rubriek bevat niet de insecten beten maar wel beten van andere dieren dan de hond of een beet van een mens. Vanuit het HIS is via NIVEL Zorgregistraties eerste lijn data verkregen over het aantal personen dat na een hondenbeet medische hulp heeft gezocht bij de huisarts ${ }^{18}$. (https://www.nivel.nl/nl/NZR/incidentiesen-prevalenties).

NIVEL Zorgregistraties eerste lijn maakt gebruik van gegevens die routinematig in de zorg worden verzameld waarvan in 2015435 huisartsenpraktijken gegevens leverden met in totaal 1.640.030 ingeschreven patiënten (https://www.nivel.nl/nl/nzr/over-nivel/methode-huisartsen).

${ }^{18}$ De incidentieschatting voor Amsterdam is in 2010 en 2011 gebaseerd op een vrij kleine steekproef uit de huisartspraktijken

74 | Wageningen Livestock Research Rapport 1024 


\section{Eerste hulp ziekenhuis en ziekenhuisopname}

In het Letsel Informatie Systeem (LIS) van VeiligheidNL staan slachtoffers geregistreerd die na een ongeval, geweld of zelfbeschadiging zijn behandeld op een Spoedeisende Hulp (SEH) afdeling, of zijn opgenomen in het ziekenhuis, van een selectie van ziekenhuizen in Nederland. De selectie aan ziekenhuizen vormen volgens VeiligheidNL een representatieve steekproef van ziekenhuizen in Nederland met een continu bezette SEH-afdeling. Hierop gebaseerd maakt VeiligheidNL een schatting van cijfers op nationaal niveau. In de praktijk komt deze methode erop neer dat het aantal SEHbehandelingen ten gevolge van letsel in de steekproef vermenigvuldigd wordt met het quotiënt van het 'aantal SEH-behandelingen in Nederland' gedeeld door het 'aantal SEH-behandelingen in de ziekenhuizen in de steekproef'. Eén persoon kan meerdere keren de SEH-afdeling bezoeken, al dan niet voor hetzelfde letsel en telt dan meerdere keren mee in de cijfers (VeiligheidNL). Hondenbeten staan geregistreerd onder code S13.

Bij VeiligheidNL zijn voor deze rapportage de cijfers opgevraagd voor 2010 tot en met 2015 over bezoeken ten gevolge van letsel door een bijtincident aan de Spoed Eisende Hulp (SEH) en ziekenhuisopname in Nederland en apart voor Amsterdam. Cijfers voor 2016 waren nog niet beschikbaar ten tijde van deze rapportage.

Bron: (VeiligheidNL, 2017). 


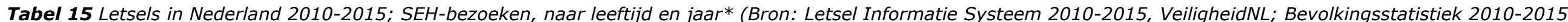
Centraal Bureau voor de Statistiek)

\begin{tabular}{|c|c|c|c|c|c|c|c|c|c|c|c|c|c|c|c|c|c|c|}
\hline & 2010 & & & 2011 & & & 2012 & & & 2013 & & & 2014 & & & 2015 & & \\
\hline Leeftijd & Aantal & $\%$ & $\begin{array}{l}\text { Aantal per } \\
100.000 * *\end{array}$ & Aantal & $\%$ & $\begin{array}{l}\text { Aantal per } \\
100.000 * *\end{array}$ & Aantal & $\%$ & $\begin{array}{l}\text { Aantal per } \\
100.000 * *\end{array}$ & Aantal & $\%$ & $\begin{array}{l}\text { Aantal per } \\
100.000^{* *}\end{array}$ & Aantal & $\%$ & $\begin{array}{l}\text { Aantal per } \\
100.000 * *\end{array}$ & Aantal & $\%$ & $\begin{array}{l}\text { Aantal per } \\
100.000^{* *}\end{array}$ \\
\hline 0-5 jaar & 300 & 7 & 27 & 300 & 7 & 30 & 200 & 6 & 22 & 200 & 6 & 18 & 200 & 5 & 15 & 200 & 7 & 18 \\
\hline 0-2 jaar & 100 & 3 & 24 & 100 & 3 & 22 & & & & & & & & & & & & \\
\hline 3-4 jaar & 100 & 3 & 28 & 100 & 3 & 39 & 100 & 3 & 36 & & & & & & & & & \\
\hline
\end{tabular}

5 jaar

\begin{tabular}{|c|c|c|c|c|c|c|c|c|c|c|c|c|c|c|c|c|c|c|}
\hline 6-12 jaar & 400 & 9 & 26 & 300 & 6 & 21 & 300 & 8 & 25 & 200 & 7 & 17 & 300 & 9 & 20 & 200 & 9 & 18 \\
\hline 13-17 jaar & 300 & 6 & 26 & 300 & 6 & 26 & 200 & 5 & 20 & 200 & 5 & 16 & 100 & 4 & 12 & 100 & 4 & 11 \\
\hline 18-24 jaar & 400 & 10 & 29 & 500 & 10 & 34 & 500 & 12 & 35 & 300 & 9 & 20 & 300 & 10 & 20 & 300 & 10 & 17 \\
\hline $\begin{array}{l}25 \text { jaar en } \\
\text { ouder }\end{array}$ & 2,900 & 68 & 25 & 3,300 & 71 & 28 & 2,900 & 69 & 25 & 2,300 & 72 & 19 & 2,200 & 72 & 18 & 1,800 & 69 & 15 \\
\hline Totaal & 4,200 & 100 & 25 & 4,700 & 100 & 28 & 4,200 & 100 & 25 & 3,200 & 100 & 19 & 3,000 & 100 & 18 & 2,600 & 100 & 15 \\
\hline
\end{tabular}

$*$ Lege cel $=$ aantal te klein voor betrouwbare schatting

** Aantal SEH-bezoeken per 100.000 inwoners in betreffende leeftijdscategorie 


\section{Aantal overledenen door een beet of aanval van een hond in de doodsoorzakenstatistiek van het CBS}

Het Centraal Bureau voor Statistiek (CBS) publiceert gegevens over doodsoorzaken van alle overleden inwoners in Nederland waaronder dood aan de gevolgen van een hondenbeet of aanval (www.cbs.nl/nl-nl/onze-diensten/methoden/onderzoeksomschrijvingen/korteonderzoeksbeschrijvingen/doodsoorzakenstatistiek). Registratie van het aantal overledenen gebeurde tot 1996 onder de code E906. Daarna onder code W54. De versiewijziging van de Classificatie van Ziekten heeft volgens het CBS geen veranderingen met zich mee gebracht (www.cbs.nl/nl$\mathrm{nl} /$ maatwerk/2008/25/gegevens-over-overledenen-aan-hondenbeten-en-enkele-andere-zeldzamedoodsoorzaken). Strikt genomen zouden onder de codes E906 en W54 gevallen kunnen voorkomen die niet gebeten zijn, maar bijvoorbeeld door een hond bestormd zijn, en dan ongelukkig terecht gekomen zijn bij een val.

Tabel 16 Aantal overledenen aan beet/aanval hond in Nederland per jaar van 1982 tot en met 2015 (Bron: CBS, code E906 en na 1995 code W54)

\begin{tabular}{|c|c|c|c|}
\hline \multicolumn{4}{|c|}{ geslacht } \\
\hline leeftijdsklasse & Man & Vrouw & totaal \\
\hline 0 jaar & 2 & 1 & 3 \\
\hline 1 tot 4 jaar & 2 & 1 & 3 \\
\hline 5 tot 9 jaar & 1 & 1 & 2 \\
\hline 35 tot 39 jaar & 2 & 0 & 2 \\
\hline 40 tot 44 jaar & 2 & 2 & 4 \\
\hline 45 tot 49 jaar & 3 & 0 & 3 \\
\hline 50 tot 54 jaar & 2 & 0 & 2 \\
\hline 55 tot 59 jaar & 1 & 1 & 2 \\
\hline 60 tot 64 jaar & 1 & 0 & 1 \\
\hline 65 tot 69 jaar & 1 & 0 & 1 \\
\hline 70 tot 74 jaar & 2 & 0 & 2 \\
\hline 75 tot 79 jaar & 2 & 2 & 4 \\
\hline
\end{tabular}

\section{Dierenarts eerstelijns en specialist}

Uitsluitend via de afdeling chirurgie van de spoedkliniek van het Medisch Centrum voor Dieren in Amsterdam (MCD-AniCura) waren gegevens beschikbaar over het aantal patiënten waarvoor na een bijtincident diergeneeskundige hulp is ingeroepen. MCD-Unicura geeft aan dat de meeste bijttrauma's via de eerstelijns spoedartsen zijn doorverwezen. Vanaf 2013 tot half november 2017 zijn er 33 patiënten aangeboden. Dit betreft die dieren die de operatiekamer haalden. Een onbekend aantal eerder overleden dieren zijn hierin niet inbegrepen. Bovendien zijn honden die door de eerstelijns spoedartsen van het MCD zijn behandeld ook niet meegeteld. Honden met kleinere verwondingen waarvoor geen specialistische zorg was vereist blijven daarmee ook buiten beeld.

\section{In beslag genomen honden}

Honden kunnen na een bijtincident in beslag worden genomen (Schilder, Van Eijken and Vinke, 2012). Procedureel gezien is inbeslagname en opslag vergelijkbaar met dat van goederen en honden worden door de wetgever als een zaak gezien. Een in beslag genomen hond wordt in bewaring gegeven bij de Rijksdienst voor Ondernemend Nederland (RVO.nl) die de honden onder brengt in opvangcentra.

Hoewel de situatie sindsdien is veranderd, kan op basis van de evaluatie in 2008 niet worden uitgesloten dat de meeste houders van honden van het type Pitbull, hun hond op een juiste manier 
houden waardoor er geen ongelukken gebeuren. Uit de evaluatie van destijds bleek dat 'slechts' $7 \%$ van de in de regio Rotterdam in beslag genomen honden van dit type betrokken was bij een bijtincident, maar ook dat in de 60 strafzaken naar aanleiding van een bijtincident meer dan de helft van de bijters tot dit type behoorde (Cornelissen en Hopster, 2008). Dit schetst direct de complexiteit van het probleem. De oorsprong van een bijtincident ligt in de combinatie van eigenaar en hond waarbij ook de omstandigheden een rol spelen (RDA, 2017). 



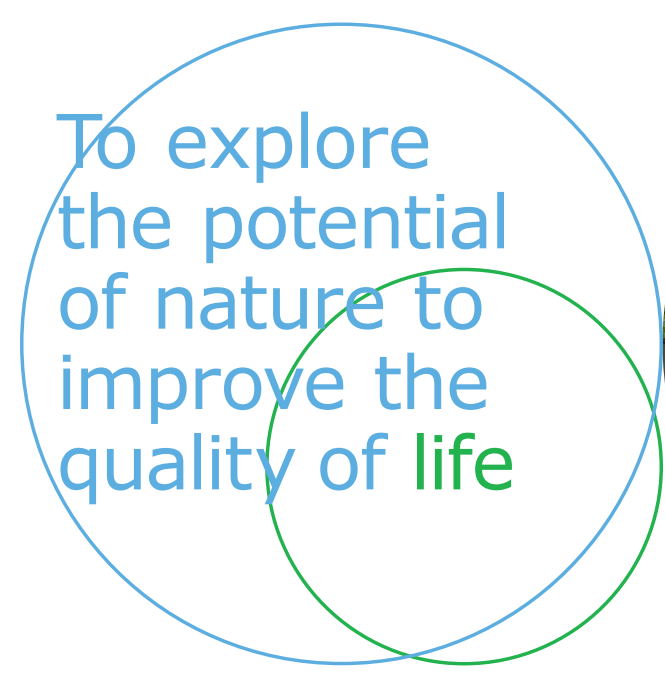

Wageningen Livestock Research Postbus 338 $6700 \mathrm{AH}$ Wageningen

T 0317483953

E info.livestockresearch@wur.nl www.wur.nl/ livestock-research

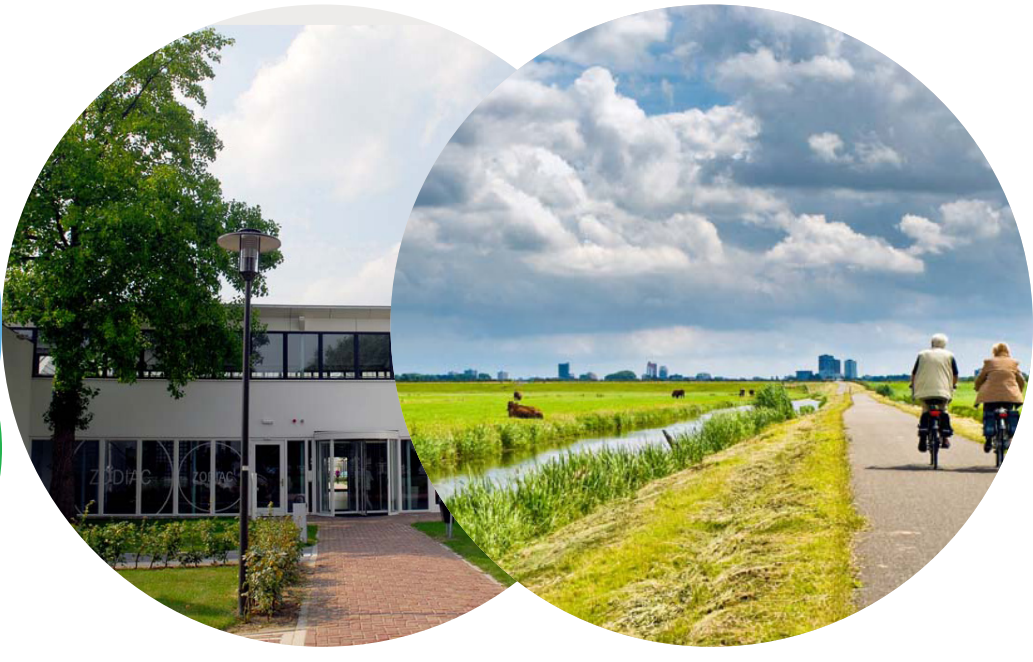

Wageningen Livestock Research ontwikkelt kennis voor een zorgvuldige en renderende veehouderij, vertaalt deze naar praktijkgerichte oplossingen en innovaties, en zorgt voor doorstroming van deze kennis. Onze wetenschappelijke kennis op het gebied van veehouderijsystemen en van voeding, genetica, welzijn en milieu-impact van landbouwhuisdieren integreren we, samen met onze klanten, tot veehouderijconcepten voor de $21 \mathrm{e}$ eeuw.

De missie van Wageningen University \& Research is 'To explore the potential of nature to improve the quality of life'. Binnen Wageningen University \& Research bundelen 9 gespecialiseerde onderzoeksinstituten van Stichting Wageningen Research en Wageningen University hun krachten om bij te dragen aan de oplossing van belangrijke vragen in het domein van gezonde voeding en leefomgeving. Met ongeveer 30 vestigingen, 6.500 medewerkers en 10.000 studenten behoort Wageningen University \& Research wereldwijd tot de aansprekende kennisinstellingen binnen haar domein. De integrale benadering van de vraagstukken en de samenwerking tussen verschillende disciplines vormen het hart van de unieke Wageningen aanpak. 